\title{
Treated Wastewater and Nitrate Transport Beneath Irrigated Fields near Dodge City, Kansas
}

\author{
Marios Sophocleous ${ }^{1}$, Margaret A. Townsend ${ }^{1}$, Fred Vocasek ${ }^{2}$, Liwang $\mathrm{Ma}^{3}$, and Ashok KC ${ }^{1}$ \\ ${ }^{1}$ Kansas Geological Survey, University of Kansas, Lawrence, KS \\ ${ }^{2}$ Servi-Tech Laboratories, Agri/Environmental Consulting, Dodge City, KS \\ ${ }^{3}$ Agricultural Research Service, U.S. Department of Agriculture, Fort Collins, CO
}

\begin{abstract}
Use of secondary-treated municipal wastewater for crop irrigation south of Dodge City, Kansas, where the soils are mainly of silty clay loam texture, has raised a concern that it has resulted in high nitratenitrogen concentrations $(10-50 \mathrm{mg} / \mathrm{kg})$ in the soil and deeper vadose zone, and also in the underlying deep (20-45 m) ground water. The goal of this field-monitoring project was to assess how and under what circumstances nitrogen $(\mathrm{N})$ nutrients under cultivated corn that is irrigated with this treated wastewater can reach the deep ground water of the underlying High Plains aquifer, and what can realistically be done to minimize this problem. We collected 15.2-m-deep cores for physical and chemical properties characterization; installed neutron moisture-probe access tubes and suction lysimeters for periodic measurements; sampled area monitoring, irrigation, and domestic wells; performed dye-tracer experiments to examine soil preferential-flow processes through macropores; and obtained climatic, crop, irrigation, and $\mathrm{N}$-application rate records. These data and additional information were used in the comprehensive Root Zone Water Quality Model (RZWQM2) to identify key parameters and processes that influence N losses in the study area. We demonstrated that nitrate-N transport processes result in significant accumulations of $\mathrm{N}$ in the thick vadose zone. We also showed that nitrate-N in the underlying ground water is increasing with time and that the source of the nitrate is from the wastewater applications. RZWQM2 simulations indicated that macropore flow is generated particularly during heavy rainfall events, but during our 2005-06 simulations the total macropore flow was only about $3 \%$ of precipitation for one of two investigated sites, whereas it was more than $13 \%$ for the other site. Our calibrated model for the two wastewater-irrigated study sites indicated that reducing current levels of corn $\mathrm{N}$ fertilization by half or more to the level of 170 $\mathrm{kg} /$ ha substantially increases N-use efficiency and achieves near-maximum crop yield. Combining such measures with a crop rotation that includes alfalfa should further reduce the amounts of residual $\mathrm{N}$ in the soil, as indicated in one of the study sites that had alfalfa in past crop rotations.
\end{abstract}

\section{Introduction}

With increasingly limited ground-water resources, reuse of treated municipal wastewater provides an alternative source of irrigation water for crops and landscaping. In addition, utilization of the nutrients in recycled wastewater as fertilizer may decrease the need for commercial fertilizers. However, municipal wastewater can contain high levels of nitrogen (N) and other constituents, such as salt, heavy metals, and pharmaceuticals (Pettygrove and Asano, 1985; Toze, 2006; Kinney et al., 2006), which can be detrimental to surface- and ground-water supplies if not carefully applied. Nitrate-N leaching into ground water is widespread in the U.S. Central Plains and elsewhere, and has been linked to the overapplication of commercial fertilizers or animal waste (Bruce et al., 2003). The environmental impacts of treated wastewaterirrigation practices need to be evaluated to determine if and when these practices may affect ground water and what management practices can be changed to slow the downward migration of the particular nutrient of concern, nitrate-N, due to its potential to contaminate drinking-water sources. Understanding the environmental impacts of wastewaterirrigation activities can be addressed by careful field-data collection and analysis in combination with simulation models capable of assessing the consequences of certain factors and farming practices on $\mathrm{N}$ losses to the environment.

Bond (1998) pointed out the conflicting requirements of effluent irrigation, namely that leaching down the salts is essential to prevent salinization of the root zone, yet leaching will result in the movement of salt- and N-laden water to the deeper vadose zone and ground water. Research challenges in effluent irrigation include quantitative prediction of $\mathrm{N}$ transformations to evaluate scenarios for $\mathrm{N}$ management, and development of specific and more rigorous guidelines for wastewater applications (Bond, 1998).

Preferential flow occurring to some degree in most soils (Shipitalo and Edwards, 1996) is now generally recognized. In some soils, macropores can serve as important pathways for preferential flow that allows rapid gravitational flow of the free wastewater available at the soil surface or of the accumulated soil water above an impeding soil horizon, thus bypassing the soil matrix. Short-circuiting to ground water through macropores is of serious concern because of the possibilities of rapid transport of a portion of fertilizers, pesticides, and other chemicals applied on the soil surface. It is generally known that under flood or high-rate sprinkler 
irrigation, when water is allowed to pond on the soil surface, transport down preferential pathways becomes more likely and deep movement of solutes can be expected (Magesan et al., 1999). Flury et al. (1994) in a dye-tracing field study of 14 different sites found significant differences both in the flow patterns and depth of dye penetration for sprinkling versus flood irrigation, with the latter resulting in a dye penetration twice as deep as that for sprinkling, despite the fact that the intensity of the sprinkler system used was relatively high $(96 \mathrm{~mm} / \mathrm{hr})$. As macropore development, preservation, and continuity can be strongly affected by soil management, such concerns have been exacerbated by the growing practice of minimum or no tillage. No-till allows chemical solutes in surface water applied on the soil to accumulate and enter macropores at the land surface; it also retains plant residues on the land surface thus enhancing worm activity and allowing worm holes and other macropore channels to stay open (Ahuja et al., 1993).

A long-term crop-irrigation project with treated wastewater south of Dodge City in semiarid to subhumid southwestern Kansas (fig. 1), which is underlain by the High Plains aquifer, is the focus of this study. Although the study area is characterized by a deep water table (ranging from 20 to $45 \mathrm{~m}$ below ground surface) and soils with a silty clay component (predominantly Harney and Ulysses silt loams, Dodge et al., 1965), evidence suggests nitrate- $\mathrm{N}$ is migrating to those water-table depths through the vadose zone (Zupancic and Vocasek, 2002). The use of the treated wastewater has resulted in relatively high soil nitrate-N concentrations (10-50 $\mathrm{mg} / \mathrm{kg}$ ) in the soil profile at the sites irrigated with this treated effluent, as well as in nitrate- $\mathrm{N}$ concentrations in ground water from a number of monitoring wells in the area exceeding the U.S. Environmental Protection Agency (USEPA) safe drinking-water limit of $10 \mathrm{mg} / \mathrm{L}$ (Zupancic and Vocasek, 2002). Zupancic and Vocasek (2002) estimated that once nitrate- $\mathrm{N}$ reached beyond the upper $1.5 \mathrm{~m}$ of the root zone, it could leach as much as $1.2 \mathrm{~m}$ in a wet year. Given that the average depth to the water table in the study area is more than $38 \mathrm{~m}$ (Sophocleous et al., 2006), preferential-flow processes may be involved in speeding up the transport of nitrate-N

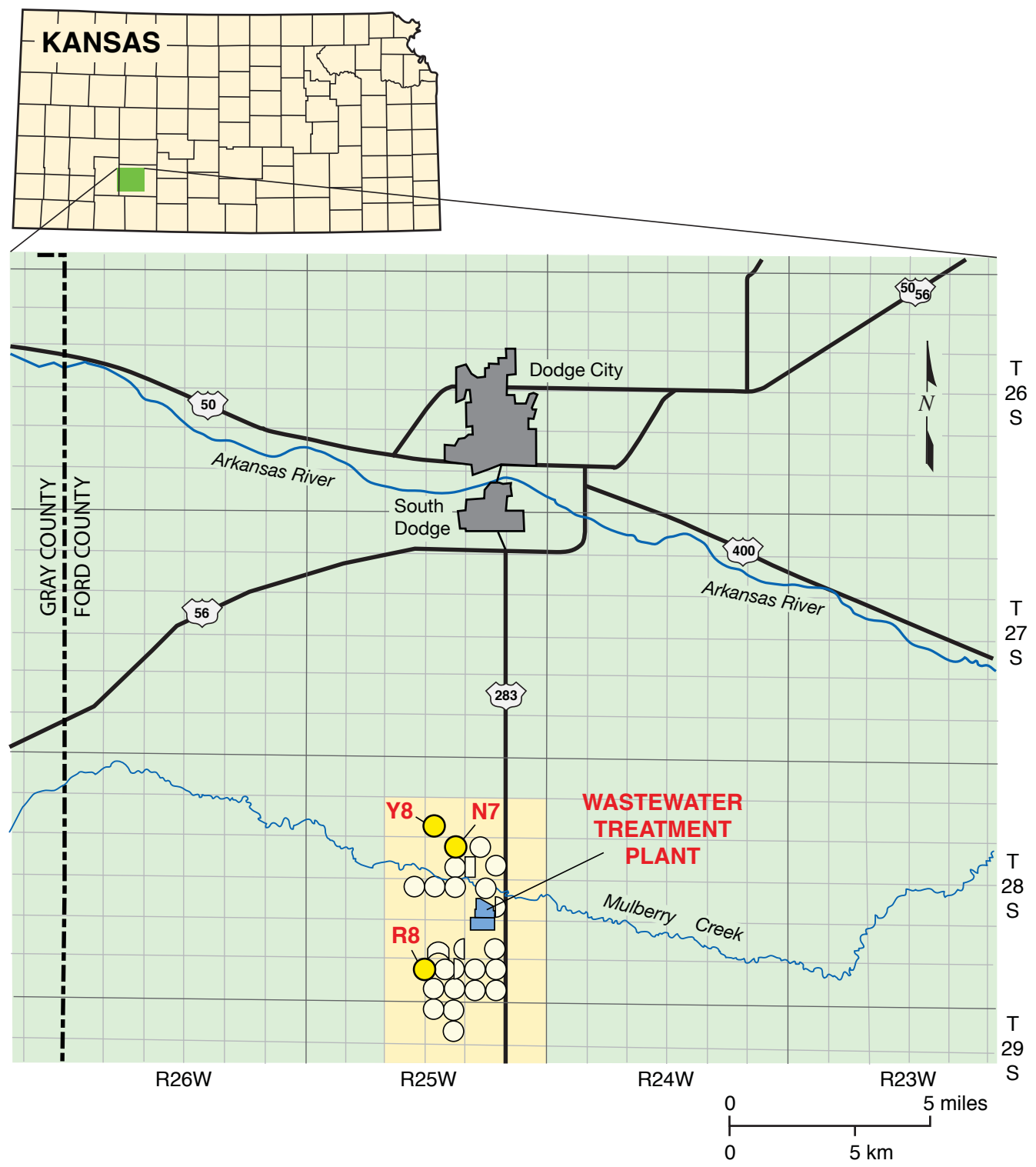

FIGURE 1-Location of the study area (highlighted). Circular areas indicate irrigated fields; bright yellow circles are the study sites. 
to the underlying water table. The U.S. Geological Survey's National Water-Quality Assessment and other studies in the central High Plains aquifer region suggest that $\mathrm{N}$ fertilizer and animal waste have reached the Ogallala portion of the High Plains aquifer due to increased recharge from irrigation and preferential-flow processes (Bruce et al., 2003).

The Root Zone Water Quality Model (RZWQM, Ahuja et al., 2000) is a deterministic model that simulates the movement of water and nutrients over and through the root zone of a representative area in an agricultural field, and which also has the capability of addressing preferential-flow processes. In this study, we used a modified version of the RZWQM, named RZWQM2, that is capable of handling the deep-vadose-zone soil profiles.

Objectives of this study were

1) to investigate the possibility of $\mathrm{N}$ leaching to ground water under secondary-treated wastewater-irrigation treatment in the study area using field sampling and monitoring; and

2) to model the above data using the RZWQM2 and to propose alternatives to current management practices.

\section{Methodology}

\section{Background}

The Dodge City Wastewater Treatment Plant collects wastewater from Dodge City and a meat-packing plant. The collected wastewater is piped $17 \mathrm{~km}$ south of the city (fig. 1) into a wastewater-treatment facility, which consists of three covered anaerobic digesters and three aeration basins. The treated water is stored in lagoons with a capacity of more than $3,454 \times 10^{3} \mathrm{~m}^{3}$. A pumping system, consisting of several centrifugal pumps, distributes the water to irrigate more than 1,100 ha of cropland in 25 fields (fig. 1-circles). The system is managed by CH2M Hill Operations Management International (OMI) and monitored by the agronomic firm Servi-Tech, Inc., under contracts with Dodge City.

\section{Field-Monitoring Sites/Field Experiments}

We established representative sites consisting of two main treated wastewater-irrigated monitoring sites (N7 and R8 in fig. 1) and one ground-water-irrigated site (control site; Y8 in fig. 1). Site R8 ( $37^{\circ} 34^{\prime} 32^{\prime \prime} \mathrm{N}, 100^{\circ} 3^{\prime} 8^{\prime \prime} \mathrm{W}$ ) has treated-wastewater irrigation history (since 1986), whereas site $\mathrm{N} 7\left(37^{\circ} 37^{\prime} 9^{\prime \prime} \mathrm{N}, 100^{\circ} 2^{\prime} 19^{\prime \prime} \mathrm{W}\right)$ has a shorter-term treated-wastewater irrigation history since 1998. Crop-history records indicate that corn (Zea mays L.) was planted at site N7 each year since 1998, and at site R8 since 2003. From 1997 to 2002, site R8 was planted with alfalfa (Medicago sativa). In 2005, sites N7 and R8 were planted with corn on April 22-23, whereas site Y8 was planted with sorghum (milo). In 2006, all three sites were planted with corn. A LEPA-sprinkler irrigation system applied the treated wastewater at an average rate of 7.3 $\mathrm{mm} /$ day for Site N7, and $6.1 \mathrm{~mm} /$ day for Site R8.

On April 5, 2005, we collected three deep (15.2-m) soil cores from each of the sites for a number of physical and chemical analyses using a truck-mounted Giddings probe. Textural, soil hydraulic, and additional physical and chemical analyses were performed by NRCS personnel at the Lincoln, Nebraska, National Soils and Soil Mechanics Laboratories. (Due to sampling problems, the collected core for analyses of soil-hydraulic properties for site R8 was less than $5 \mathrm{~m}$ in length.) Nitrogen, carbon, and related analyses were conducted at Kansas State University (KSU) and ServiTech Soil Analysis Laboratories (see next section on soil and water chemical and isotopic analyses). The soil bulk density down to $15.2 \mathrm{~m}$ was determined from collected cores of known diameter by cutting the core in 15.2-cm increments, weighing them in the field, and then oven-drying them in the lab. The bulk density was also determined by the clod method (Grossman and Reinsch, 2002). Table 1 summarizes the measured soil physical properties by layer, which were subsequently used in the simulation model (explained further below).

A neutron probe (Campbell Pacific Nuclear $\{\mathrm{CPN}\}$ 503DR Hydroprobe) was used to collect moisture-data profiles to $15.2-\mathrm{m}$ depth. The neutron probe was calibrated in the field based on core measurements collected from the access-tube borehole and on "wet" and "dry" corner plots, equipped with neutron-probe access tubes that were measured occasionally. Details of neutron access-tube installation and probe calibration are available in Sophocleous et al. (2006). Periodic (twice monthly for 2005, monthly for 2006) measurements of soil-water content at $0.15-\mathrm{m}$ intervals within the upper 1.8 $\mathrm{m}$ and at $0.3-\mathrm{m}$ intervals below $1.8 \mathrm{~m}$ down to $15.2 \mathrm{~m}$ were conducted throughout the growing seasons in 2005 and 2006.

Three suction lysimeters were installed in each site at various depths, shallow (1.6-1.8 m), intermediate (5.2-8.0 $\mathrm{m}$ ), and deep (9.0-15.0 m), for collecting pore-water samples for occasional analyses. A Giddings auger was used to auger a $5.1-\mathrm{cm}$ diameter hole and to install the suction lysimeters. Silica flour was used below, around, and slightly above the sampler ceramic cup to provide good contact with the soil. Approximately $30 \mathrm{~cm}$ of pellet-sized bentonite was then added with some water on top of the silica flour. Soil was backfilled on top of that bentonite layer to within $60 \mathrm{~cm}$ of the land surface. More bentonite was added to fill the hole to the surface to prevent surface-water from entering the hole. A $0.48-\mathrm{MPa}$ vacuum pressure was put on each sample one week prior to sampling. The site R8 shallow, sites R8 and N7 intermediate-depth, and site Y8 deep lysimeters were the only ones to yield pore-water samples.

All the existing monitoring wells (14) in the area (shown in fig. 5) were sampled twice a year to check any nutrient-N impacts on the relatively deep water table, which ranges from about $21 \mathrm{~m}$ deep close to the usually dry Mulberry Creek to more than $45 \mathrm{~m}$ deep as one goes away from that creek (fig. 1). Additional water samples from monitoring, domestic, and 
TABLE 1-Measured soil physical properties for sites N7 and R8 by layer (in units employed in the RZWQM).

\begin{tabular}{|c|c|c|c|c|c|c|c|c|c|c|c|}
\hline Layer & Soil type & $\begin{array}{c}\text { Horizon } \\
\text { depth } \\
\text { (cm) }\end{array}$ & $\begin{array}{c}\text { Bulk } \\
\text { density }^{a} \\
\left(\mathrm{~g} / \mathrm{cm}^{3}\right)\end{array}$ & $\begin{array}{l}\text { Porosity } \\
\left(\mathrm{cm}^{3} / \mathbf{c m}^{3}\right)\end{array}$ & $\begin{array}{c}\text { Sand } \\
\text { fraction } \\
(\mathrm{g} / \mathrm{g})\end{array}$ & $\begin{array}{c}\text { Silt } \\
\text { fraction } \\
(\mathrm{g} / \mathrm{g})\end{array}$ & $\begin{array}{c}\text { Clay } \\
\text { fraction } \\
(g / g)\end{array}$ & $\begin{array}{c}\mathbf{K}_{\mathrm{s}}^{c} \\
(\mathrm{~cm} / \mathbf{h r})\end{array}$ & $\begin{array}{c}\text { 1/3-bar } \\
\text { W.C. }{ }^{d, 1} \\
(0.03 \\
\text { MPa) }\end{array}$ & $\begin{array}{c}\text { 15-bar } \\
\text { W.C. }{ }^{d, 2} \\
(1.5 \mathrm{MPa})\end{array}$ & $\begin{array}{c}\text { Total } \\
\text { organic } \\
\text { carbon }^{e} \\
(\%)\end{array}$ \\
\hline \multicolumn{12}{|c|}{ Site N7 } \\
\hline 1 & Silty loam & $0-23$ & 1.280 & 0.517 & 0.056 & 0.686 & 0.258 & 1.3163 & 0.2260 & 0.1305 & 1.06 \\
\hline 4 & Silty clay loam & $168-221$ & 1.240 & 0.532 & 0.114 & 0.558 & 0.328 & 0.9829 & 0.2390 & 0.1410 & 0.24 \\
\hline 5 & Silty clay loam & $221-363$ & 1.380 & 0.479 & 0.115 & 0.554 & 0.331 & 0.2266 & 0.2070 & 0.1215 & 0.21 \\
\hline 6 & Silty clay loam & $363-625$ & 1.420 & 0.464 & 0.090 & 0.610 & 0.300 & 0.5431 & 0.2310 & 0.1185 & 0.05 \\
\hline 7 & Silty loam & $625-848$ & 1.350 & 0.491 & 0.126 & 0.631 & 0.243 & 0.7048 & 0.2340 & 0.1070 & 0.03 \\
\hline 8 & Silty loam & $848-889$ & 1.380 & 0.479 & 0.141 & 0.638 & 0.221 & 0.6966 & 0.2340 & 0.1260 & 0.02 \\
\hline 1 & Silty clay loam & $0-16$ & 1.420 & 0.464 & 0.041 & 0.643 & 0.316 & 0.4480 & 0.3540 & 0.1500 & 1.66 \\
\hline 2 & Silty clay loam & $16-29$ & 1.490 & 0.438 & 0.036 & 0.659 & 0.305 & 0.4452 & 0.3530 & 0.1420 & 1.03 \\
\hline 3 & Silty clay loam & $29-50$ & 1.280 & 0.517 & 0.023 & 0.599 & 0.378 & 0.1553 & 0.3800 & 0.1780 & 0.75 \\
\hline 4 & Silty clay & $50-68$ & 1.210 & 0.543 & 0.017 & 0.553 & 0.430 & 0.0890 & 0.3950 & 0.2010 & 0.56 \\
\hline 5 & Silty clay loam & $68-90$ & 1.260 & 0.525 & 0.021 & 0.592 & 0.387 & 0.2799 & 0.3820 & 0.2170 & 0.42 \\
\hline 6 & Silty clay loam & $90-140$ & 1.520 & 0.426 & 0.030 & 0.627 & 0.343 & 0.8501 & 0.3660 & 0.1670 & 0.34 \\
\hline 7 & Silty clay loam & $140-260$ & 1.620 & 0.389 & 0.152 & 0.502 & 0.346 & 0.3237 & 0.2990 & 0.1310 & 0.17 \\
\hline 8 & Silty clay loam & $260-300$ & 1.610 & 0.392 & 0.194 & 0.483 & 0.323 & 0.1543 & 0.2800 & 0.1260 & 0.12 \\
\hline 9 & Clay loam & $300-410$ & 1.530 & 0.423 & 0.217 & 0.494 & 0.289 & 0.2968 & 0.2730 & 0.1190 & 0 \\
\hline 10 & Silty clay loam & $410-484$ & 1.540 & 0.419 & 0.188 & 0.496 & 0.316 & 0.1308 & 0.2920 & 0.1280 & 0 \\
\hline
\end{tabular}

${ }^{a}$ core method

${ }^{b}$ calculated assuming a particle density of $2.65 \mathrm{~g} / \mathrm{cm}^{3}$

${ }^{c}$ saturated hydraulic conductivity performed on collected core samples ${ }^{e}$ according to ASTM-D5084 Flexible wall permeability tests irrigation wells and wastewater lagoons were periodically collected.

To explain deep occurrences of $\mathrm{N}$ concentrations through possible preferential pathways, we conducted two dyetracer experiments in each of the two wastewater-irrigated study sites, site R8 in Harney soil (fine, superactive, mesic Pachic Argiustolls) and site N7 in Ulysses soil (fine-silty, mixed, superactive, mesic Aridic Haplustolls). Brilliant-blue food-coloring dye (FD\&C Blue 1, tri-phenyl-methane dye) was used as a tracer because of its desirable properties of mobility and distinguishability in soils, and also because of its nontoxicity (Flury and Fluhler, 1994, 1995; Flury et al., 1994). Based on these studies, a dye concentration of $4 \mathrm{~g} / \mathrm{L}$ was used to flood the test sites, which were enclosed in $91.4-\mathrm{cm}$ by $152.4-\mathrm{cm}$ wooden rectangular frames of $30.5-\mathrm{cm}$ height, with approximately $750 \mathrm{~L}$ of dye solution per test site. It is expected that ponding would generate more preferential flow than sprinkling, as also was alluded to in the introduction. Additional details on these dye-tracer tests are presented in Sophocleous et al. (2006).

\section{Soil and Water Chemical and Isotopic Analyses}

Total levels (inorganic and organic) of carbon (C) and N were determined on a dry weight-percent basis using a LECO CN 2000 combustion analyzer (LECO Corp., 1995). Calcium carbonate percentage was analyzed by pretreatment of a second LECO combustion sample with dilute $(10 \% \mathrm{v} / \mathrm{v}) \mathrm{HCl}$. The total organic carbon is the $\% \mathrm{C}$ in the acid-treated sample. The total inorganic carbon is then calculated as the difference in the treated and untreated values. Soil chloride is extracted from a 5-g sample with calcium nitrate and analyzed with the mercury thiocyanate colorimetric method.

Water analyses were conducted by the Kansas Geological Science (KGS) Analytical Services Section. The water samples were filtered through $0.45-\mu \mathrm{m}$ membrane-filter paper before analysis. Specific conductance was measured to estimate chloride concentration and determine a dilution factor for the optimum concentration range of the analytical method. Nitrate, chloride, sulfate, and bromide concentrations were determined using a Dionex ICS Series 3000 ion 
chromatograph. Bicarbonate content was computed from an alkalinity determination using an automated titrimeter. Cation concentrations were measured using an inductively coupled argon plasma spectrometer. Charge-balance errors calculated for the well waters, for which measurements of all major and substantial minor constituents were completed, were all $<2 \%$ and averaged $1.0 \%$.

Natural-abundance nitrogen-15 isotope analysis is frequently used to assist in determining sources of $\mathrm{N}$ to ground water (Heaton, 1986). Nitrogen-15 $\left(\delta^{15} \mathrm{~N}\right)$ values in the waters were determined at the Department of Environmental Sciences, University of Virginia. Samples of the dried nitrate containing salts dissolved in the waters were combusted at high temperature to $\mathrm{N}$ gas for analysis of their isotopic compositions. The $\delta^{15} \mathrm{~N}$ was determined on a Micromass Optima isotope ratio mass spectrometer (IRMS) coupled with an elemental analyzer (EA), with an overall precision better than $0.5 \%$. The data are reported relative to a standard (atmospheric $\mathrm{N}_{2}$ ) defined to be $0 \%$, and expressed in $\delta$ notation as

$$
\delta_{\text {sample }}(\% 0)=\left(\mathrm{R}_{\text {sample }} / \mathrm{R}_{\text {standard }}-1\right) \times 1000
$$

where $\delta_{\text {sample }}$ represents $\delta^{15} \mathrm{~N}$, and R is the molar ratio of the heavier $\left({ }^{15} \mathrm{~N}\right)$ to the lighter $\left({ }^{14} \mathrm{~N}\right)$ isotope for the standard or sample (Hoefs, 2001). The analyses were run on nitrate in all samples except for the wastewater samples, which were run on total N (inorganic-N + organic-N).

\section{The Root Zone Water Quality Model (RZWQM)}

The USDA-ARS developed a comprehensive agricultural systems model known as the Root Zone Water Quality Model (RZWQM) as a research tool to investigate the effects of agricultural management on crop production and environmental quality (Ahuja et al., 2000). The RZWQM is an integrated physical, biological, and chemical process model that simulates plant growth, and the movement and interactions of water, nutrients, and pesticides over and through the root zone for a representative area of an agricultural cropping system. It is a one-dimensional (vertical soil profile) model designed to simulate conditions on a unitarea basis. Details on all aspects of the model can be found in Ahuja et al. (2000).

The water-flow processes in the RZWQM are divided into two components: 1) infiltration into the soil matrix and macropores and macropore-matrix interaction during a rainfall or an irrigation event, modeled by using the Green and Ampt approach (Green and Ampt, 1911); and 2) redistribution of water in the soil matrix following infiltration, estimated by a mass-conservative numerical solution of the Richards' equation (Celia et al., 1990). Rainfall or irrigation water in excess of the soil-infiltration capacity (overland flow) is routed into macropores if present. The maximum macropore flow rate and lateral water movement into macropores in the surrounding soil are computed using Poiseuilles' law and the lateral Green-Ampt equation, respectively. Macropore flow in excess of its maximum flow rate or excess infiltration is routed to runoff. In the RZWQM, water can only enter the macropores at the surface. High-intensity rainfalls generally yield greater water flow and chemical transport in macropores than low-intensity rainfalls (Shipitalo and Edwards, 1996), and this is true with the RZWQM as well.

The hydraulic properties are defined by the soil-water characteristic or retention curves, and the unsaturated hydraulic-conductivity function. Those relationships are described by functional forms suggested by Brooks and Corey (1964) with slight modifications (Ahuja et al., 2000).

The volumetric soil-water content $(\theta)$ versus the capillary pressure head or matric suction head $(\psi)$ relationship representing the water retention or characteristic curve is formulated as follows:

$$
\begin{aligned}
& \theta(\psi)=\theta_{s}-A_{1}|\psi| \text { for }|\psi| \leq\left|\psi_{a}\right| \\
& \theta(\psi)=\theta_{r}+B|\psi|^{-\lambda} \text { for }|\psi|>\left|\psi_{a}\right|
\end{aligned}
$$

where $\theta_{s}$ and $\theta_{r}$ are the saturated and residual soil-water contents $\left(\mathrm{cm}^{3} / \mathrm{cm}^{3}\right)$, respectively; $\psi_{a}$ is the air-entry or bubbling suction head $(\mathrm{cm}) ; \lambda$ is the pore-size distribution index (and represents the logarithmic slope of the waterretention curve); $A_{1}$ and $B$ are constants, where $B=$ $\left(\theta_{s}-\theta_{r}-A_{1} \psi_{a}\right) \psi_{a}^{\lambda}$ and $A_{1}$ was set to zero in our case, thus reducing equations (1) and (2) to the Brooks and Corey (1964) model. The Brooks-Corey parameters were obtained by fitting the RETC (RETention Curve) program (van Genuchten et al., 1991) to measured soil-moisture data.

The hydraulic conductivity $(\mathrm{K})$ versus matric suction head $(\psi)$ relationship representing the unsaturated hydraulicconductivity function is formulated as follows:

$$
\begin{aligned}
& K(\psi)=K_{s}|\psi|^{-N_{1}} \text { for }|\psi| \leq\left|\psi_{a}\right| \\
& K(\psi)=K_{2}|\psi|^{-N_{2}} \text { for }|\psi|>\left|\psi_{a}\right|
\end{aligned}
$$

where $K_{s}$ is the saturated hydraulic conductivity; $N_{1}, N_{2}$, and $K_{2}$ are constants; and $K_{2}=K_{s}\left|\psi_{a}\right|^{-N_{2}} ; N_{2}=2+3 \lambda$, and $N_{1}$ was set to zero in our case, thus reducing equations (3) and (4) to the Brooks and Corey (1964) model.

The soil carbon/nitrogen dynamics module of the RZWQM model (Shaffer et al., 2000) contains two surfaceresidue pools (fast and slow decomposition), three soilhumus pools (slow, medium, and fast decomposition), and three soil-microbial pools (aerobic heterotrophs, autotrophs, and anaerobic heterotrophs). Despite the complexity of this organic-matter/N-cycling component, good estimates of initial soil-carbon content and nitrogen are generally the only site-specific parameters needed. The required inputs (e.g., fast pool, slow pool) are then usually determined through an initiation wizard and calibration (Ma et al., 1998).

The RZWQM included a generic crop model that can be parameterized to simulate specific crops (Hanson, 2000). However, the latest version of RZWQM2 (version $1.5)$ incorporated the Decision Support System for Agrometeorology Transfer, DSSAT4.0 suite of crop models (www.icasa.net/dssat/index.html; Ritchie et al., 1998), which can simulate detailed yield components and phenological development for specific crops. Of particular interest in our 
study is the corn model CERES-Maize, available as part of the DSSAT4.0. The CERES-Maize model has been extensively used worldwide for development of crop-management applications (Saseendran et al., 2005).

As mentioned previously, the RZWQM is designed to analyze soil and plant processes within the root zone, which in the recently released version 1.5 , was extended down to $30-\mathrm{m}$ depth. Because of model limitations (such as allowing only up to 10 model layers), we had to combine a number of soil horizons into a maximum of 10 layers as shown in table 1. A unit gradient was assumed for the lower boundary condition, set at $10.8 \mathrm{~m}$ for site $\mathrm{N} 7$ and $4.8 \mathrm{~m}$ for site R8 (the lowest depths for which we had detailed soil hydraulic analyses). The first neutron-probe soil-water profile measurements before crop planting in April 2005 were used as the initial soil-water depth distribution in the modeling.

The model also requires detailed meteorological data, on a daily basis, and rainfall intensity data. Hourly precipitation and other meteorological data (except for solar radiation) were obtained from the Dodge City Municipal Airport weather station, $17 \mathrm{~km}$ northeast of the study sites; daily solar-radiation data were obtained from the Garden City Agricultural Experiment Station 80 km west-northwest of Dodge City, operated by Kansas State University. Due to similar geomorphic, land use/land cover, and climatic conditions between Garden City and Dodge City, no significant impacts on calculated water-budget components are expected from such climatic-data translocations. This is confirmed by comparing five years (1986-1990) of daily solar-radiation data when both Dodge City and Garden City weather stations were collecting such data (M. Knapp, Kansas State Climatologist, written communication, May 15, 2008). A linear regression of the daily average solar-radiation values at Dodge City and Garden City during the 1986-1990 period yielded an $\mathrm{R}^{2}$ of more than 0.94 (fig. 2). A year-by-year comparison indicated that the Dodge City total solar radiation as a percentage of that from Garden City was $97 \%$ for 1986 , $99 \%$ for $1987,93 \%$ for 1988 , and $100 \%$ for both 1989 and 1990 (M. Knapp, State Climatologist, written communication, May 15, 2008). The model also requires specification of cropmanagement practices such as planting and harvesting dates and specification of irrigation and fertilization events, as well as the chemical quality of irrigation.

\section{Model-Calibration Procedures}

For accurate simulations, RZWQM must be calibrated for soil hydraulic properties, nutrient properties, and plant-growth parameters for the site and crops being simulated (Hanson et. al., 1999), as there are significant interactions among the different model components. Available data for 2005 were employed in calibrating the model, whereas the available data for 2006 were reserved for verifying ("validating") the model. Calibration targets included the biweekly (during 2005) and monthly (during 2006) neutron soil-water measurements, soil nitrate- $\mathrm{N}$ analyses, and harvested-corn grain yields. The number of parameters and processes in the RZWQM are so numerous that it is exceedingly difficult to decide which ones to optimize and what optimization scheme might be appropriate, if at all feasible. As a result, such agriculturalsystem models as the RZWQM are usually parameterized by trial-and-error or iterative processes (Ahuja and Ma, 2002). In this paper, we followed the detailed procedures for calibrating the RZWQM as laid out by Hanson et al. (1999) and Ahuja and $\mathrm{Ma}$ (2002). In addition, a series of sensitivity analyses were conducted to identify the most important parameters in both the soil and plant portions of the model affecting model output and thus to use in model calibration (Sophocleous et al., 2007).

The model-calibration strategy we used was as follows: the RZWQM was first calibrated for soil hydraulic properties, which included the pore-size distribution index, $\lambda$, and the saturated soil-water content, $\theta_{s}$, for each modeled soil layer. (Sensitivity analysis indicated that these parameters were among the most sensitive in our case.) The model was then equilibrated with respect to the initial $\mathrm{C} / \mathrm{N}$ pool sizes for the fast and slow decomposition-residue pools; slow, medium, and fast decomposition-humus pools; and the three microbial pools (aerobic heterotrophs, autotrophs, and anaerobic heterotrophs) (Hanson et al., 1999). No laboratory procedures are known to effectively determine the sizes of these pools (Ahuja and $\mathrm{Ma}, 2002$ ). Therefore, because previous management at a site determines the initial state of a soil in terms of its organic matter and microbial populations, simulations with previous management practices will usually create a better initial condition for those parameters (Ma et al., 1998). After entering all the model inputs and parameters, we began by

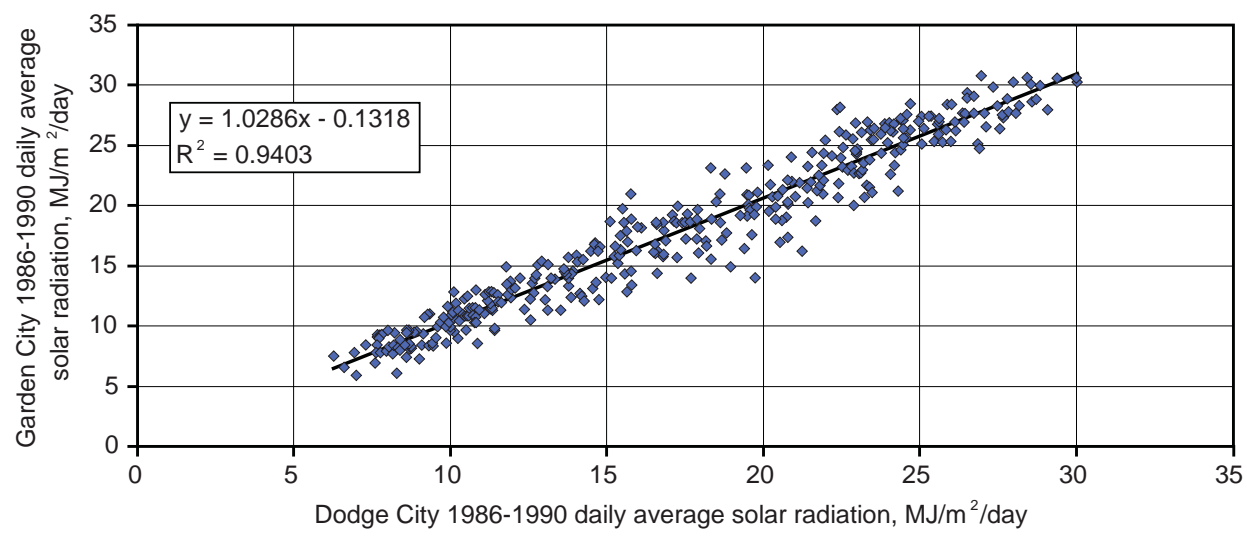

FIGURE 2-Comparison of daily average solar radiation from 1986 to 1990 for Garden City and Dodge City, Kansas. 
estimating the three humus organic-matter pool sizes (based on the measured organic-carbon depth profiles shown in table 1) at 5,10 , and $85 \%$, for fast, medium, and slow pools, respectively, and set the microbial pools at 50,000,500, and 5,000 organisms per gram of soil, respectively, for aerobic heterotrophs, autrotrophs, and facultative heterotrophs, as recommended by Ahuja and Ma (2002). RZWQM was initialized for the organic-matter pools by running the model for 12 years prior to the 2005-06 actual simulation periods. A 12-year initialization run was suggested by Ma et al. (1998) to obtain steady-state conditions for the faster soil organic pools.

Following initialization and equilibration of the carbon and nitrogen $(\mathrm{C} / \mathrm{N})$ pool, the crop parameters were calibrated by trial-and-error adjustments to match observed crop phenology and yield as simulated by the CERES-Maize dedicated corn model, available as part of the DSSAT4.0 suite of crop models incorporated in the latest model version RZWQM2. Nutrient (nitrogen) and plant (corn) components are interrelated because adjustment of crop parameters affects both nitrate-leaching loss and crop yield. Corn calibration parameters included four phenological and two growth parameters as follows: i) thermal time from seedling emergence to the end of the juvenile phase (P1, expressed in degree days above a base temperature of $\left.8^{\circ} \mathrm{C},{ }^{\circ} \mathrm{Cd}\right)$; ii) photoperiodism coefficient ( $\mathrm{P} 2$, expressed as days delay in tassel initiation per hour increase in photoperiod, $\mathrm{d} / \mathrm{hr}$ ); iii) thermal time from silking to physiological maturity $\left(\mathrm{P} 5,{ }^{\circ} \mathrm{Cd}\right)$; iv) thermal time between successive leaf-tip appearances, known as phyllochron interval (PHINT, ${ }^{\circ} \mathrm{Cd}$ ); v) maximum possible number of kernels per plant (G2); and vi) kernelfilling rate (G3, $\mathrm{mg} / \mathrm{d})$. We based adjustments of these parameters for corn within the range of values used for Kansas environments (Pachta, 2007; Dogan et al., 2006; Roman-Paoli et al., 2000; Kiniry et al., 1997).

Because the N-related and plant-growth parameters are difficult to measure with independent experiments, an accurate description of the soil-water-related processes as far as possible is required to minimize $\mathrm{N}$-simulation errors. Therefore, particular effort was expended in calibrating the soil-water hydrologic processes first before proceeding with the plant and N-related parameter calibration.

\section{Statistics Used in Model Evaluation}

Three statistics were used to evaluate the simulation results: i) root mean squared error (RMSE) between simulated and observed values, eq. (5); ii) relative root mean square error (RRMSE), i.e., RMSE relative to the mean of the observed values, eq. (6); and iii) mean relative error (MRE) or bias, eq. (7).

$$
\begin{aligned}
& \text { RMSE }=\sqrt{\frac{1}{n} \sum_{i=1}^{n}\left(S_{i}-O_{i}\right)^{2}} \\
& \text { RRMSE }=\text { RMSE } \times \frac{100 \%}{O_{\text {avg }}} \\
& \text { MRE }=\frac{1}{n} \sum_{i=1}^{n} \frac{S_{i}-O_{i}}{O_{i}} \times 100 \%
\end{aligned}
$$

where $S_{i}$ is the $i$ th simulated value, $O_{i}$ is the $i$ th observed value, $O_{a v g}$ is the average of observed values, and $n$ is the number of data pairs.

The RMSE reflects the magnitude of the absolute mean difference between simulated and experimental results, whereas the RRMSE standardizes the RMSE and expresses it as a percentage that represents the standard variation of the estimator (Abrahamson et al., 2005). The MRE indicates if there is a systematic bias in the simulation. A positive value indicates an overprediction and a negative value an underprediction.

\section{Alternative Management Simulations and Nitrogen-Use Efficiency (NUE)}

Several management scenarios were simulated using reduced fertilization treatments of $50 \%$ and $40 \%$ of the actually applied wastewater-N totals at site N7 during 2005 and 2006. Also, reduced irrigation totals of 88,75 , and $50 \%$ of actually applied amounts in 2005 were evaluated while maintaining the same irrigation scheduling. In all the abovementioned management scenarios, the resulting Nitrogen-Use Efficiency (NUE, see further below) and grain yields were evaluated.

Nitrogen-Use Efficiency (NUE) is a term used to indicate the relative balance between the amount of fertilizer $\mathrm{N}$ taken up and used by the crop versus the amount of fertilizer $\mathrm{N}$ "lost," and can be defined as follows (Hu et al., 2006):

$\mathrm{NUE}=\frac{(\text { Plant } \mathrm{N} \text { uptake for particular } \mathrm{N} \text { treatment })-(\text { Plant } \mathrm{N} \text { uptake for zero- } \mathrm{N} \text { treatment })}{(\text { Total amount of } \mathrm{N} \text { applied })}(8)$

To compute NUE, the RZWQM2 model was re-run with a zero-N treatment, and the results were used in eq. (8).

\section{Results and Discussion}

\section{Wastewater, Soil-Water, and Ground- Water Quality}

The daily precipitation and irrigation events during the years 2005 and 2006 for site N7 are shown in fig. 3. The chloride concentrations of the applied treated-wastewater effluent were around the $300-\mathrm{mg} / \mathrm{L}$ level, but further increased during the second half of 2006, and the Total Kjeldahl Nitrogen concentrations (TKN) were generally above the
$80 \mathrm{mg} / \mathrm{L}$ level for site N7 (fig. 4). The average electrical conductivity (EC) of the effluent applied for 2005 was 2.11 $\mathrm{mS} / \mathrm{cm}$ for site $\mathrm{N} 7$ and $2.07 \mathrm{mS} / \mathrm{cm}$ for site R8 (2.63 and 2.43 $\mathrm{mS} / \mathrm{cm}$, respectively for 2006), whereas the sodium adsorption ratio (SAR) for 2005 was 5.17 for site $\mathrm{N} 7$ and 7.04 for site R8 (6.34 and 5.98, respectively, for 2006). Both EC and SAR values exceed the Servi-Tech, Inc. agronomic consulting firm's recommendations of keeping EC not greater than $1.5 \mathrm{mS} / \mathrm{cm}$ and SAR values to less than 5.0 to avoid salinity problems 
Site N7, 2005 Irrigation and Precipitation

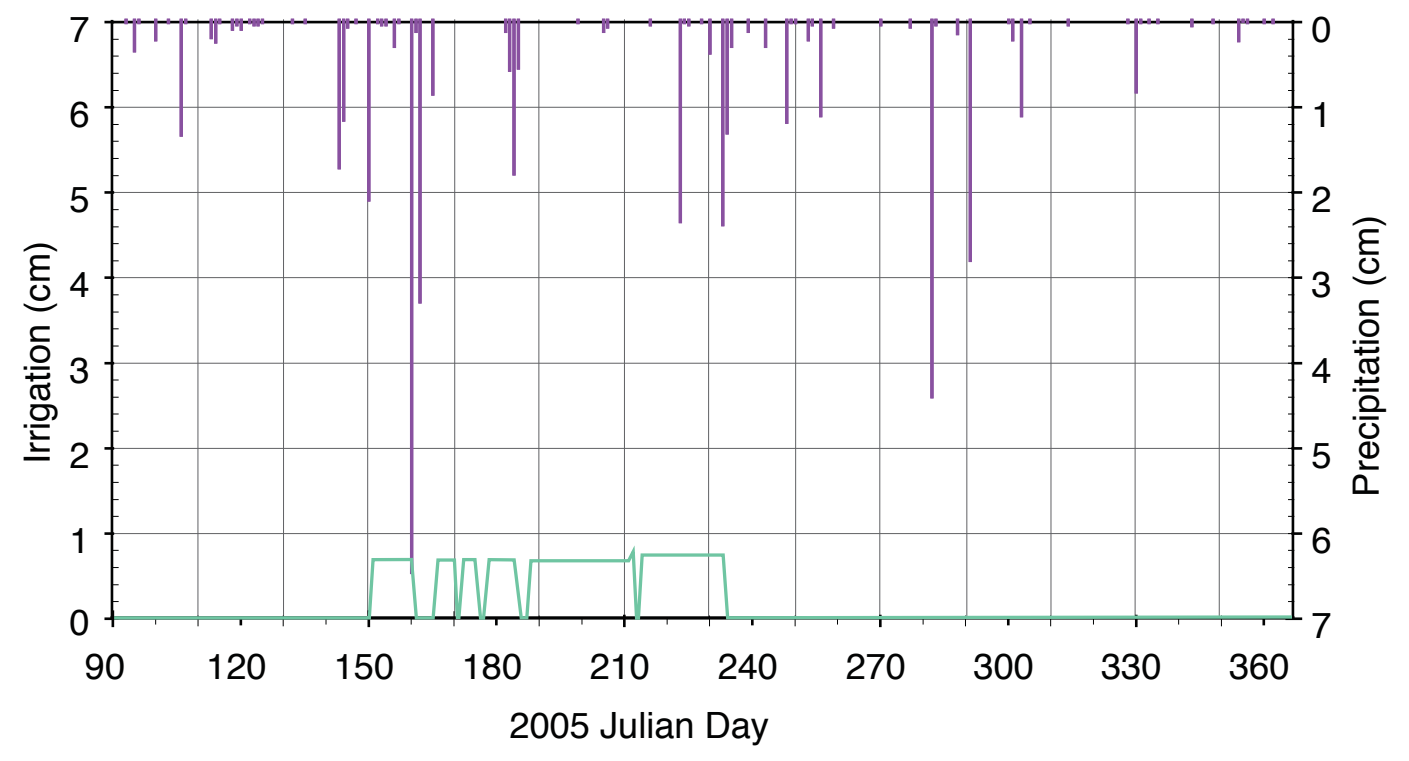

Irrigation -Precipitation

FIGURE 3-Daily precipitation and irrigation events during the years 2005 and 2006 at site N7. Zero values in the lower irrigation display (in green color) indicate times when the irrigation system was shut off.

a.
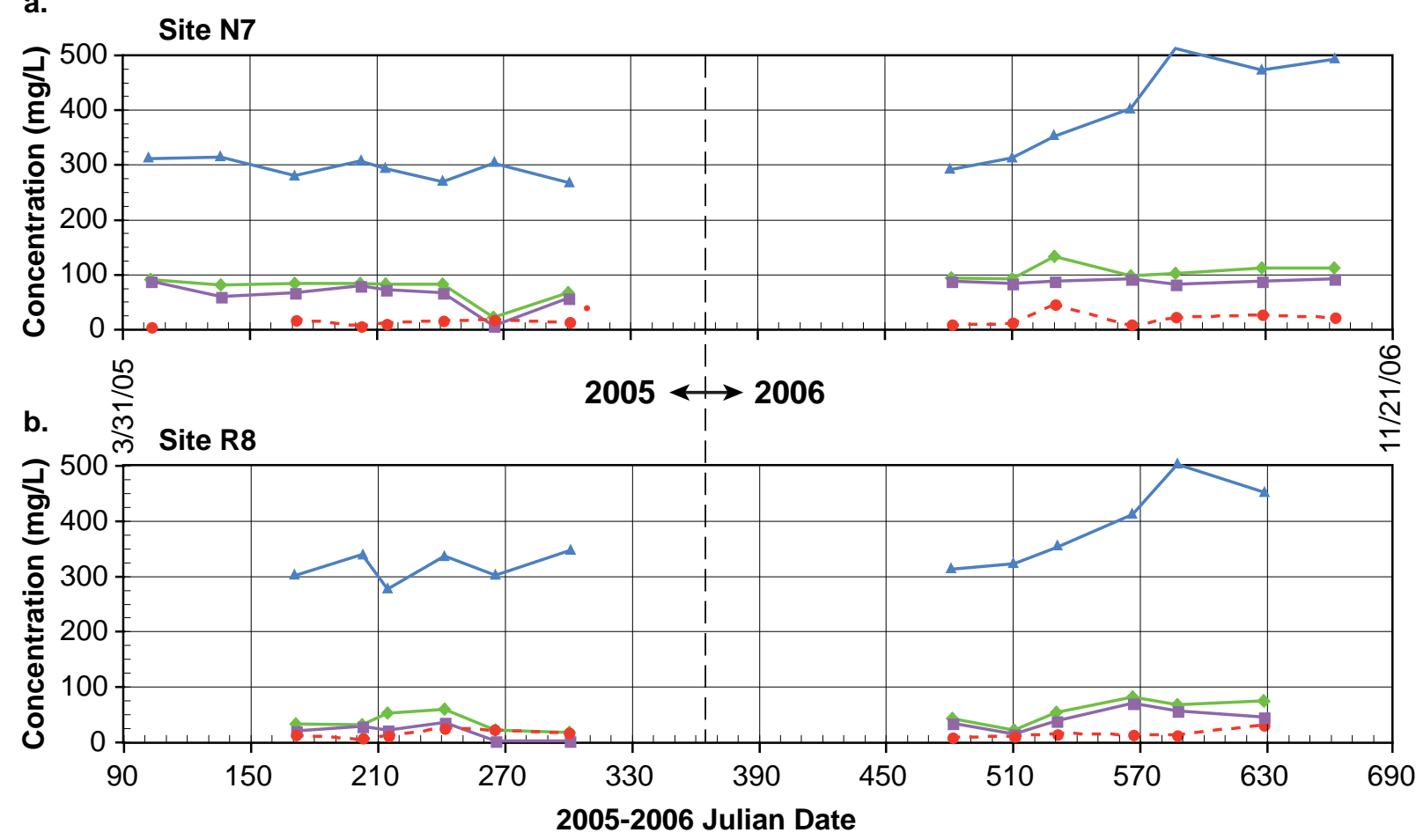

2005-2006 Julian Date

$\longrightarrow \mathrm{TKN} \longrightarrow \mathrm{NH} 4-\mathrm{N}---\bullet--$ Organic-Nitrogen $\longrightarrow \mathrm{Cl}$

FIGURE 4-Treated effluent irrigation-water chloride, total Kjeldahl nitrogen (TKN), ammonia-nitrogen $\left(\mathrm{NH}_{4}-\mathrm{N}\right)$, and organic nitrogen concentration time series applied to sites N7 (a) and R8 (b) during 2005 and 2006. The nitrate-N concentration (not displayed) is of the same order of magnitude as organic- $\mathrm{N}$ in this graph. 
eventually impacting crop yields (Zupancic and Vocasek, 2002). Following agronomic recommendations, the farmers averted further salt buildup on crop leaves by converting their sprinklers from higher-pressure overhead nozzles to lower-pressure drop nozzles, and also by applying gypsum treatments to soils with high exchangeable sodium percentage (Zupancic and Vocasek, 2002).

Figure 5 shows the ground-water nitrate- $\mathrm{N}$ concentrations from the November 2005 survey sampling. The general ground-water flow in the study area is from west to east based on annually measured water levels by the Kansas Geological Survey (www.kgs.ku.edu/Hydro/Levels/). Wells shown in solid red-brown symbols exceed the safe drinking-water limit for nitrate-N of $10 \mathrm{mg} / \mathrm{L}$. Notice that most of the wells have more than $2 \mathrm{mg} / \mathrm{L}$ nitrate- $\mathrm{N}$ in the ground water. This indicates that anthropogenic sources have begun to impact the ground water in the area (Mueller and Helsel, 1996). The temporal evolution of nitrate-N in ground water since 1988 will be described in the next section together with the temporal evolution of soil nitrate-N.

Table 2 shows the range of observed $\mathrm{N}$ concentrations and $\delta^{15} \mathrm{~N}$ values for different sources. Figure 6 shows the relationship between median $\mathrm{N}$ concentrations and $\delta^{15} \mathrm{~N}$ values for wastewater lagoon, lysimeter, and monitoring-well samples at the field sites. Samples with $\delta^{15} \mathrm{~N}$ values greater than $+10 \%$ and median $\mathrm{N}$ values greater than $10 \mathrm{mg} / \mathrm{L}$ indicate a likely animal-waste source (treated wastewater) for the nitrogen. The lysimeter soil-water samples from sites N7 and R8 plot in the area of the wastewater lagoon, indicating the rapid movement of wastewater to depth (N7 medium-depth lysimeter $5.3 \mathrm{~m}, \mathrm{R} 8$ medium-depth lysimeter $8 \mathrm{~m}$, and R8 shallow-depth lysimeter $1.6 \mathrm{~m}$ ).

The irrigation-well sample from site Y8 (control site) shows a $\delta^{15} \mathrm{~N}$ value in the range of fertilizer. This site is irrigated with ground water, not wastewater. The Y8 deeplysimeter sample at 8.8-m depth shows a somewhat enriched $\delta^{15} \mathrm{~N}$ value (9.5\%) which may reflect volatilization of applied fertilizer and/or microbial degradation of $\mathrm{N}$ as water moved through the vadose zone at this site. This site has no known animal-waste source of fertilizer.

Wells with median $\mathrm{N}$ values between 4 and $10 \mathrm{mg} / \mathrm{L}$ and $\delta^{15} \mathrm{~N}$ values above $+10 \%$ indicate a mixing of wastewater and regional ground water (fig. 6). Wells with median $\mathrm{N}$ values below $4 \mathrm{mg} / \mathrm{L}$ and $\delta^{15} \mathrm{~N}$ values below $+8 \%$ (fertilizer range) generally occur along the periphery of the wastewaterirrigation sites. The observed values from these wells are most likely regional ground water impacted by microbially degraded and/or volatilized fertilizer $\mathrm{N}$.

Chemical ratios can indicate mixing of regional ground water with reclaimed water. Boron/chloride ratios $(\mathrm{B} / \mathrm{Cl})$ were used to indicate mixing of recycled wastewaters in studies in California and Israel (Kaehler and Belitz, 2003; Vengosh et al., 1999). Bromide/chloride ratios $(\mathrm{Br} / \mathrm{Cl})$ have been used in Kansas and elsewhere to indicate various salinity sources, including treated wastewater (Whittemore, 1995; Vengosh and Pankratov, 1998; Townsend and Whittemore, 2005). Most of the monitoring-well samples at the study site with $\delta^{15} \mathrm{~N}$ values below $+10 \%$ (triangles, fig. 6 ) had chloride values of less than $15 \mathrm{mg} / \mathrm{L}$, boron/chloride ratios greater than 2.5 , and bromide/chloride ratios greater than 60 , which are indicators of minimally impacted ground waters (table 2).

The wells, lysimeters, and lagoons with enriched $\delta^{15} \mathrm{~N}$ values $>+10 \%$ (squares, fig. 6) had boron/chloride ratios less than 2.5 , bromide/chloride ratios less than 60 , and chloride concentrations of greater than $15 \mathrm{mg} / \mathrm{L}$ (table 2). This range of values indicates that these monitoring wells are most likely impacted by the wastewater application. The presence of enriched $\delta^{15} \mathrm{~N}$ values and boron/chloride and bromide/chloride ratios in the wastewater range in the lysimeters helps support the observation of macropore flow at the sites.

Figure 7 displays a tri-linear diagram (Hem, 1985) with the average water quality (major anions and cations) of the irrigation water applied in both R8 and N7 sites marked as the A-oval, and the shallow- and intermediate-depth suctionlysimeter-sampled pore water from both sites marked as the B-oval. Figure 7 also displays the water quality of the sampled (November 2005) domestic, monitoring, and irrigation wells in the area. The deeper ground-water quality in the general area is a calcium bicarbonate type water characterized by relatively low nitrate and chloride concentrations (fig. 7) with specific conductance around $400 \mu \mathrm{S} / \mathrm{cm}$. The sampled populations of applied wastewater, pore water from suction lysimeters, and monitoring and domestic wells form distinct groups in the tri-linear diagram (fig. 7).

TABLE 2 - Criteria for nitrogen sources, and freshwater and wastewater sources from published and unpublished data.

\begin{tabular}{|c|c|c|c|}
\hline Range of $\delta^{15} \mathrm{~N}(\%)$ & \multicolumn{2}{|c|}{ Nitrogen Sources } & Reference \\
\hline$<8$ & Fertilizer ( Ni & $\mathrm{N}>2 \mathrm{mg} / \mathrm{L})$ & Heaton (1986) \\
\hline 8 to 10 & Mixed sources (Var & range of nitrate-N) & Kreitler (1975) \\
\hline$>10$ & $\begin{array}{l}\text { Animal waste (1) } \\
\text { Enrichme } \\
\text { Volatilization ( } \\
\text { Denitrification }\end{array}$ & $\begin{array}{l}\mathrm{e}-\mathrm{N}>10 \mathrm{mg} / \mathrm{L} \text { ) } \\
\text { ocesses: } \\
\mathrm{e}-\mathrm{N}>10 \mathrm{mg} / \mathrm{L} \text { ) } \\
\text { te- } \mathrm{N}<1 \mathrm{mg} / \mathrm{L} \text { ) }\end{array}$ & Townsend et al. (1996) \\
\hline \multicolumn{4}{|c|}{ Water Source } \\
\hline Parameter & Fresh Water & Wastewater & Reference \\
\hline $\mathrm{B} / \mathrm{Cl} \times 10^{3}$ & $>2.5$ & $<2.5$ & Kaehler and Blitz (2003); Vengosh et al. (1999) \\
\hline $\mathrm{Br} / \mathrm{Cl} \times 10^{4}$ & $>60$ & $<60$ & \multirow{2}{*}{$\begin{array}{l}\text { Whittemore (1995); Townsend and Whittemore } \\
\text { (2005); Townsend (2009) unpublished data }\end{array}$} \\
\hline Chloride (mg/L) & $<15$ & $>15$ & \\
\hline
\end{tabular}




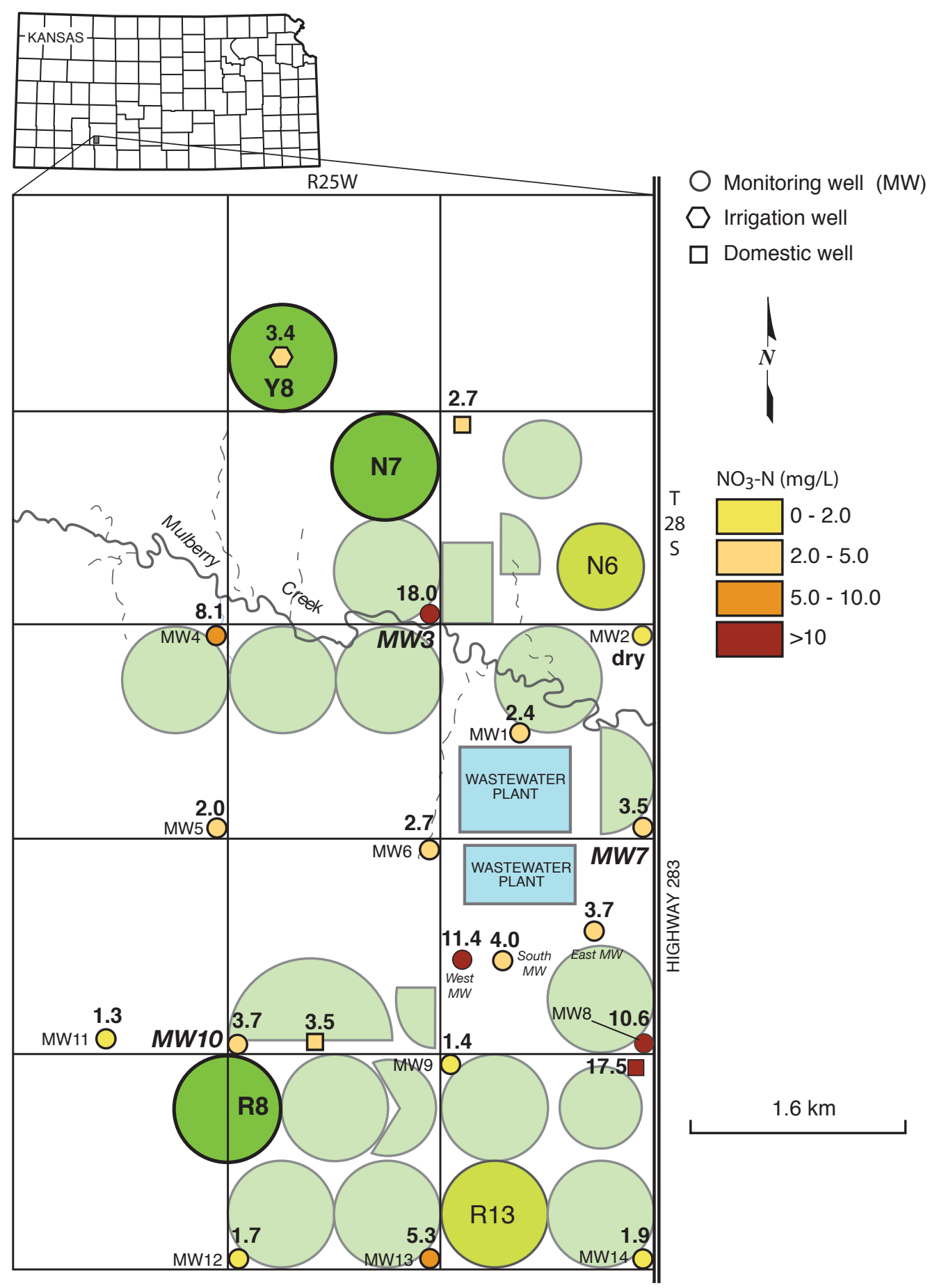

FIGURE 5-Ground-water nitrate-N concentrations during November 2005. Bold numbers above well symbols indicate ground-water nitrate-N concentrations $(\mathrm{mg} / \mathrm{L})$. Circles/semicircles are irrigated fields; the study sites are highlighted. Time series distributions of ground-water nitrate-N for monitoring wells MW3, MW7, and MW10 (indicated in bold letters in the figure) are displayed in fig. 10. 


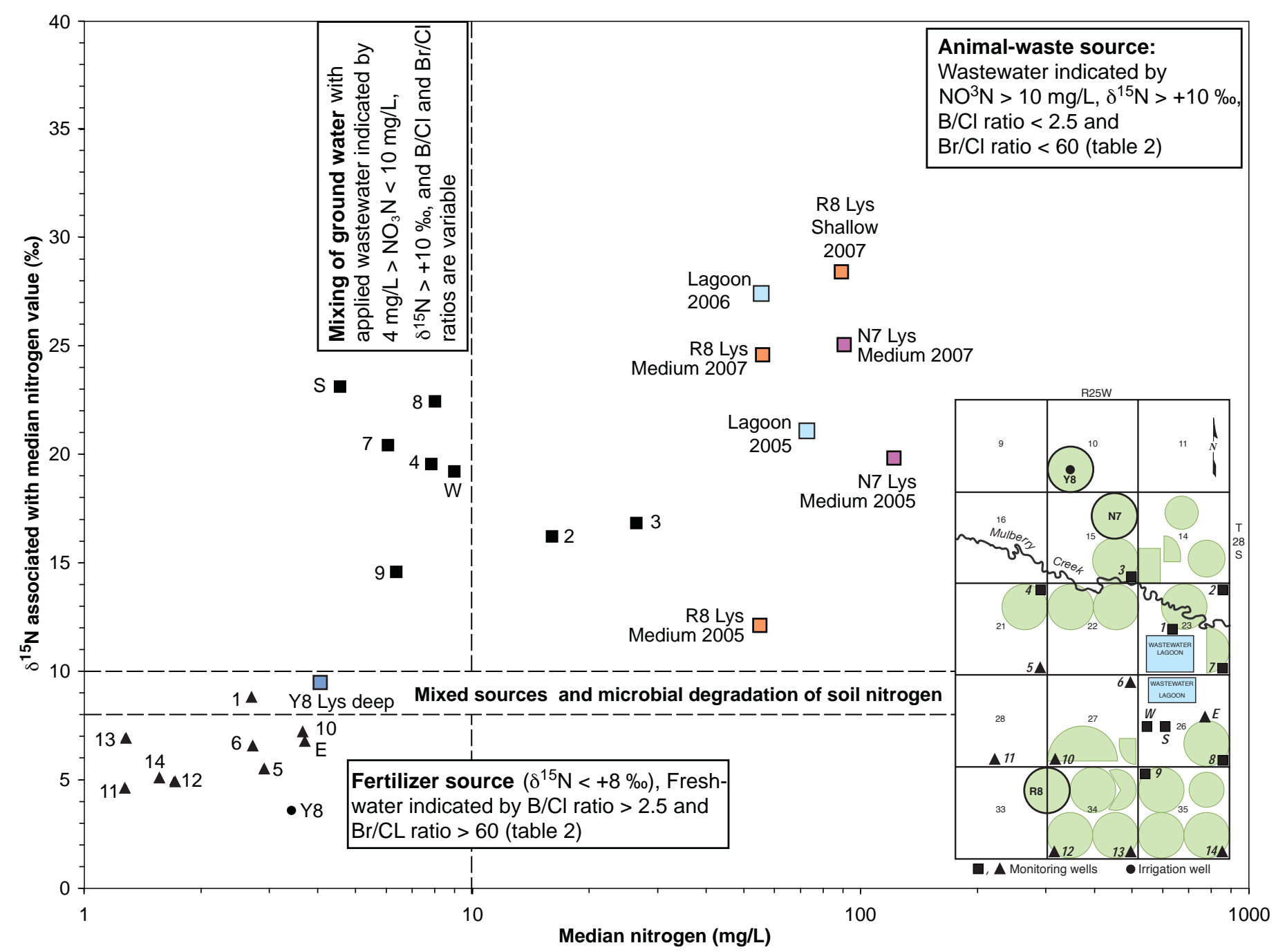

FIGURE 6-Graph shows location of monitoring wells in relation to nitrogen and $\delta^{15} \mathrm{~N}$ values. Black triangles are wells with median nitrogen values less than $4 \mathrm{mg} / \mathrm{L}$ and $\delta^{15} \mathrm{~N}$ values less than $+10 \%$; black squares indicate wells with median nitrogen values greater than $4 \mathrm{mg} / \mathrm{L}$ and $\delta^{15} \mathrm{~N}$ values above $+10 \%$. Numbers and letters indicate monitoring wells, the locations of which are shown in the inset diagram. Letters E, S, and $\mathrm{W}$ indicate location of monitoring wells relative to wastewater lagoon. Lys indicates lysimeter soil-water sample. Letter and number combinations (Y8, R8, N7) indicate irrigated field study sites that were sampled. Light-green circles are irrigated fields.

\section{Soil Nitrate and Chloride Profiles}

High nitrate-N and chloride concentrations were found in the soil profile at all sites sampled as seen in figs. 8 and 9 for sites N7, R8, and Y8, respectively. The data for the spring of 2005, which were used as the initial conditions for the RZWQM, indicated the R8 (a site with a long-term wastewater-irrigation history - since 1986) had a high nitrate peak of about $40 \mathrm{mg} / \mathrm{kg}$ around $60 \mathrm{~cm}$, which decreases sharply to $0.7 \mathrm{mg} / \mathrm{kg}$ level in the depth interval of 380 to $580 \mathrm{~cm}$ (fig. 8a). This decrease is possibly due to previously planted alfalfa roots consuming the nitrate at those depths, as the R8 site was cropped in alfalfa from 1997 to 2002 . The nitrate increases again reaching a secondary maximum of about $7.2 \mathrm{mg} / \mathrm{kg}$ near the depth of $870 \mathrm{~cm}$, then following a decrease near the $940-\mathrm{cm}$ level to the $3-\mathrm{mg} / \mathrm{kg}$ level, it progressively increases with depth down to more than 1,500 $\mathrm{cm}$, reaching the $10-\mathrm{mg} / \mathrm{kg}$ level. It seems that a previous nitrate front has reached down to $1,500 \mathrm{~cm}$, with yet older fronts reaching even deeper, indicating that nitrate may have previously penetrated to those depths. The chloride profile (fig. 9) shows a peak around the depth of $320 \mathrm{~cm}$, and follows a near-constant profile below $620 \mathrm{~cm}$. For site N7 (with wastewater-irrigation history since 1998; fig. 8b) a deeper nitrate peak (of less than $28 \mathrm{mg} / \mathrm{kg}$, i.e., not as high as that at site R8) was observed around the 240-cm-depth level, which also coincides with the corresponding chloride peak at that level (fig. 9). Then, the nitrate distribution progressively decreases to a minimal background level $(0.4 \mathrm{mg} / \mathrm{kg})$ near $940 \mathrm{~cm}$, indicating that nitrate penetrated to that depth but no further. A second chloride peak occurs just above that level. Finally, for site Y8 (without any wastewater irrigation), a high nitrate peak was observed near the $100-\mathrm{cm}$ level, but at the $570-\mathrm{cm}$ depth level, nitrate goes back to minimal background level (1.2 mg/kg; fig. 8c). However, the chloride profile reaches its peak around that level (fig. 9). 
Legend:

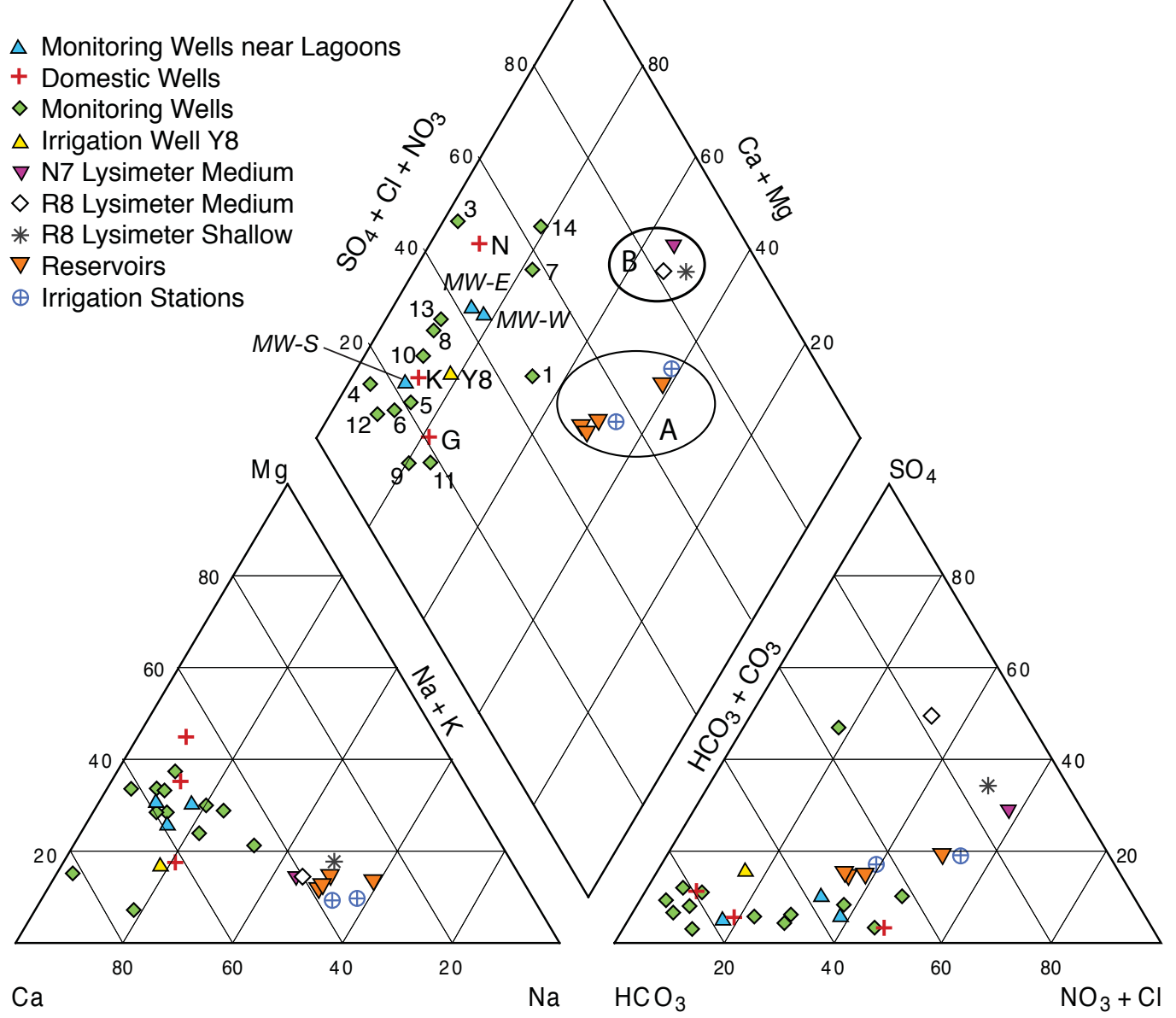

FIGURE 7-Tri-linear diagram showing the average 2005 quality of irrigation water applied in sites R8 and N7 (oval A), the shallow and intermediate-depth suction lysimeter-sampled pore water from sites R8 and N7 (oval B), and the domestic, monitoring, and irrigation wells (with their letter/number designations) sampled in the area.

Lysimeter water samples showed higher nitrate- $\mathrm{N}$ and chloride concentrations $(\mathrm{mg} / \mathrm{L})$ than in the samples extracted from the soils. The $\delta^{15} \mathrm{~N}$ values for the lysimeter water samples at sites $\mathrm{N} 7$ and $\mathrm{R} 8$ are in the animal-waste range $(>+10 \%)$ expected from municipal wastewater. The enriched $\delta^{15} \mathrm{~N}$ values, plus the observed nitrate- $\mathrm{N}$ concentrations above the U.S. EPA 10-mg/L drinking-water limit in the lysimeter samples, strongly suggest that macropore flow is influencing the ground-water quality in the area. Generally in soils, enriched $\delta^{15} \mathrm{~N}$ values are accompanied by decreasing nitrate- $\mathrm{N}$ values because of denitrification of the $\mathrm{N}$ by soil bacteria (Broadbent et al., 1980; Karamanos et al., 1981; Rennie et al., 1976; Shearer et al., 1978; Townsend and Macko, 2007). A continuously decreasing nitrate- $\mathrm{N}$ concentration is not observed with depth in either the R8 or N7 cores (figs. 8 and 9 ). Variation in the $\mathrm{N}$ concentration was mainly related to varying crops planted at the sites.
Although the irrigation-well-water sample for site $\mathrm{Y} 8 \mathrm{had}$ a nitrate-N value of $3.4 \mathrm{mg} / \mathrm{L}$ (fig. 6), chloride concentration of $14 \mathrm{mg} / \mathrm{L}$, and a $\delta^{15} \mathrm{~N}$ value of $3.6 \%$, the lysimeter nitrate- $\mathrm{N}$ value was $4.1 \mathrm{mg} / \mathrm{L}$ with a $\delta^{15} \mathrm{~N}$ value of $9.5 \%$. The increase in the $\delta^{15} \mathrm{~N}$ value suggests the possibility of volatilization of applied fertilizer and/or microbial degradation of $\mathrm{N}$. The lower $\delta^{15} \mathrm{~N}$ and nitrate- $\mathrm{N}$ values for the lysimeter sample at $\mathrm{Y} 8$ relative to the average lysimeter values at sites $\mathrm{R} 8$ and N7 suggest that the source of the nitrate and the processes affecting the $\mathrm{N}$ content are different.

Examination of soil-core data in nearby wastewaterirrigated sites (N6 and R13, shown in fig. 5) as well as groundwater samples from nearby monitoring wells (MW3, MW7, MW10, also shown in fig. 5) collected by OMI personnel, show progressive increases with time in both vadose-zone nitrate storage and ground-water nitrate- $\mathrm{N}$ with statistically significant increasing trend (using the Mann-Kendall test for trend [Helsel and Hirsch, 2002]; fig. 10). 


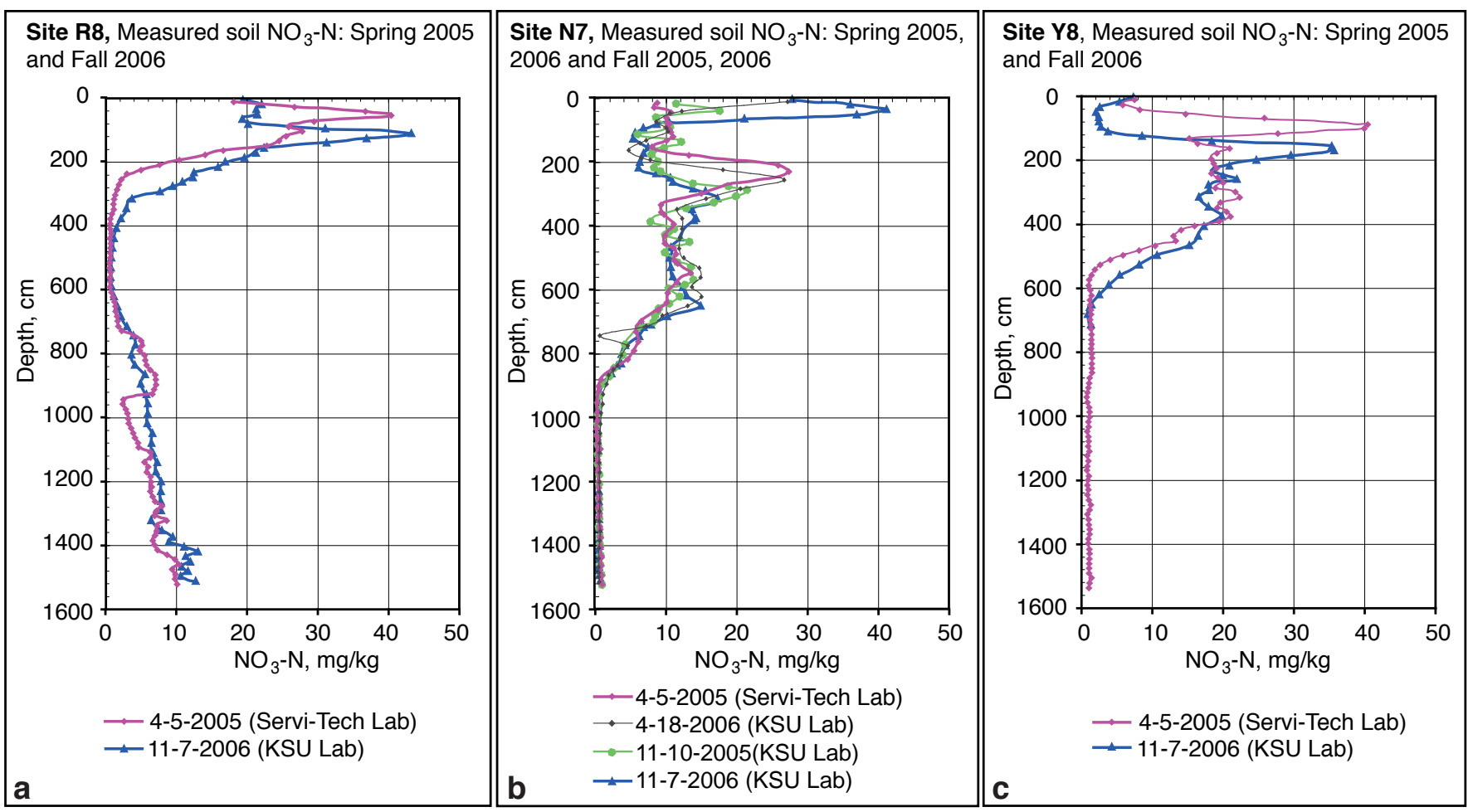

FIGURE 8-Measured soil profile nitrate-N at various times during 2005 and 2006 for the study sites (a-R8, b-N7, and c-Y8).

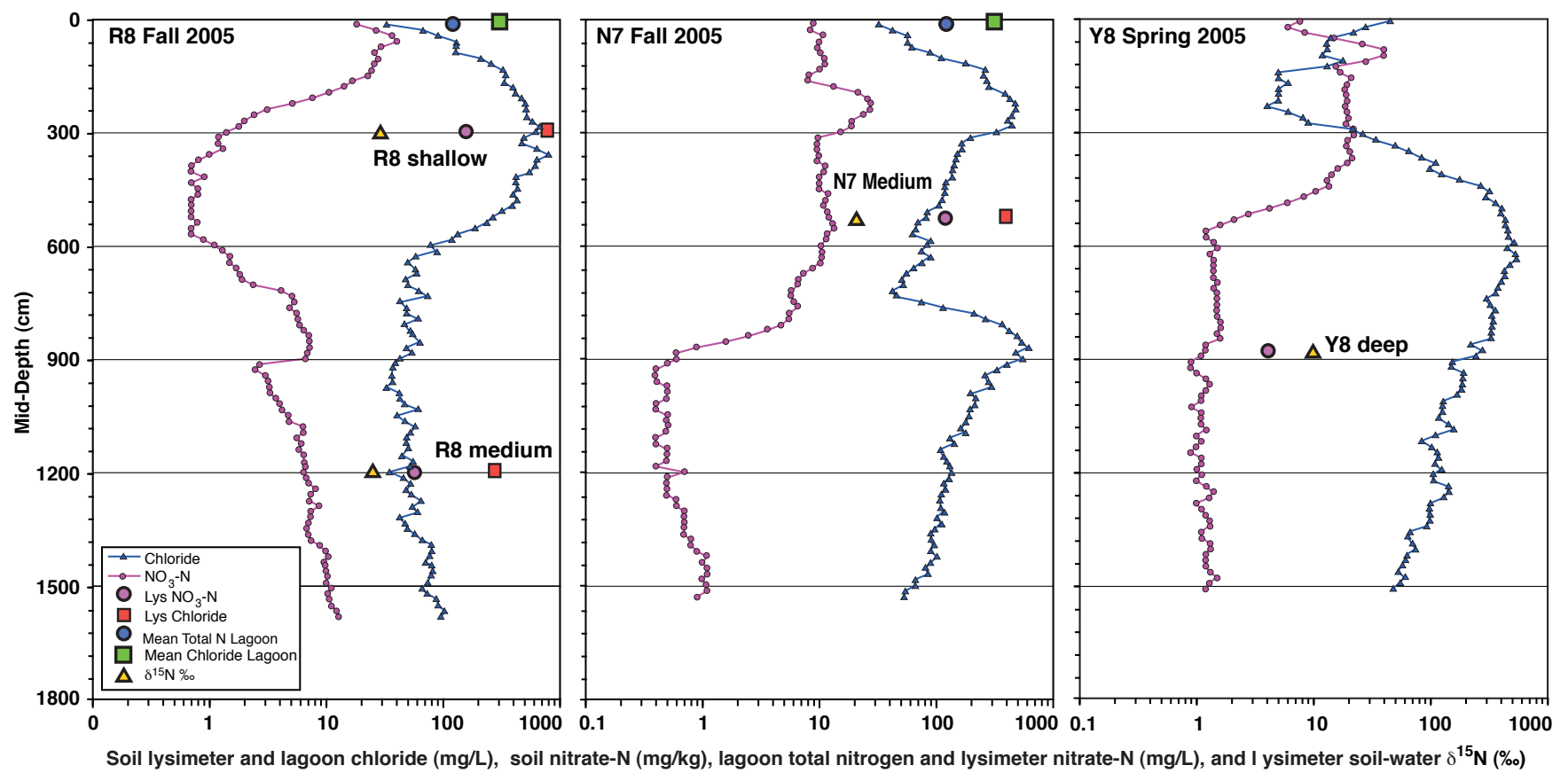

FIGURE 9-Soil nitrate-N and chloride profiles from Y8, N7, and R8 sites. Storage-lagoon total nitrogen and chloride are shown, as well as nitrate-N, chloride, and $\delta^{15} \mathrm{~N}(\%)$ values from lysimeter soil-water samples. 

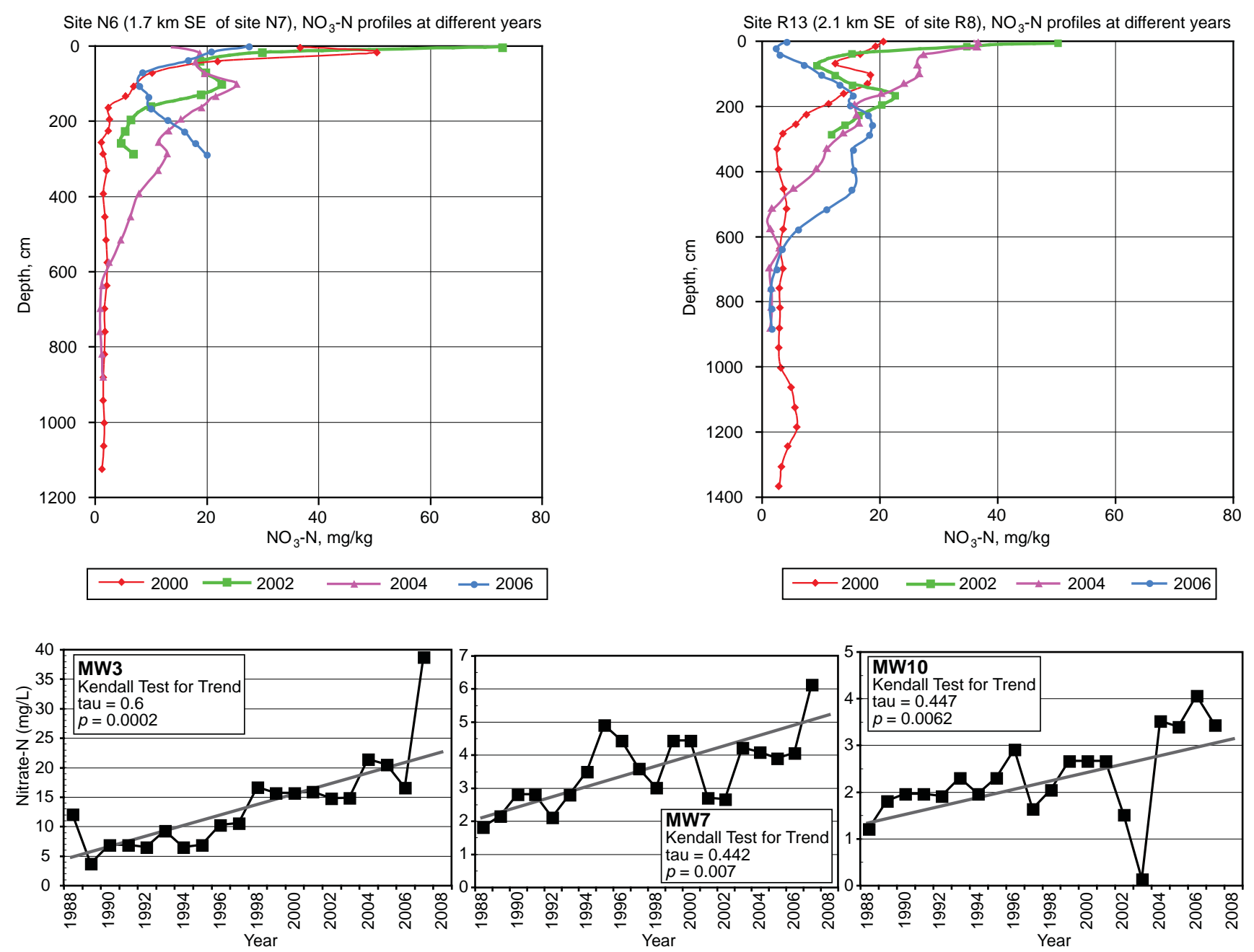

FIGURE 10-Time evolution of (upper panel) vadose-zone nitrate profiles for sites N6 and R13, indicated in fig. 5, and (lower panel) ground-water nitrate-N from selected monitoring wells (MW), also indicated in fig. 5. Mann-Kendall trend line and related statistics also are indicated, where tau is the non-parametric equivalent of the parametric statistical correlation coefficient, and $p$ is the calculated probability level that is compared to the significance level, $\alpha$, which was set to 0.10 . Depth to water table for wells MW3, MW7, and MW10 were 22.6, 32.0, and $33.5 \mathrm{~m}$, respectively, during the November 2005 measurement survey.

\section{Dye-Tracer Experiments}

Numerous macropores were observed in cores not only in the upper soil profile but also at depths down to more than $10 \mathrm{~m}$ (fig. 11; for a possible explanation see later in this section). During the dye-tracer experiment, the tracer at site R8 penetrated down to approximately $200 \mathrm{~cm}$ and formed a more-or-less uniform "finger front" at the bottom (fig. 12). The photograph on the right in fig. 12 shows evidence of dye movement through the blocky-structure soil layers of the $\mathrm{Bt}$ horizons (at approximately the 50- to $100-\mathrm{cm}$ depth interval) where the tracer moved along the spaces between the blocky soil aggregates and concentrated in numerous fingers in the lower soil layer that did not exhibit the heavy blocky structure of the Bt horizons above. For site N7, the dye pattern was different, forming a giant funnel front ending in a big finger down to more than $200 \mathrm{~cm}$ (fig. 13). Closer examination of a side finger showed that the dye finger formed along a decaying root channel, as did other fingers examined in both sites. The bottom-right core photograph of fig. 11 shows the decaying root organic material lining the macropores.

The observed macropores at depth are probably due to the existence of deep-rooted prairie grasses, which dominated the landscape prior to agricultural development. The currently practiced no-till land-use treatment further enhances worm activity near the soil surface, thus maintaining macropores open at the soil surface. Because of the existence of such preferential-flow pathways, the macropore option of the RZWQM was employed. Based on the observed macropores throughout the soil profile in both sites, macropores were uniformly distributed through all simulated layers using an average estimated pore radius of $0.1 \mathrm{~cm}$ and a percentage of macropores of $0.1 \%$ in RZWQM. 


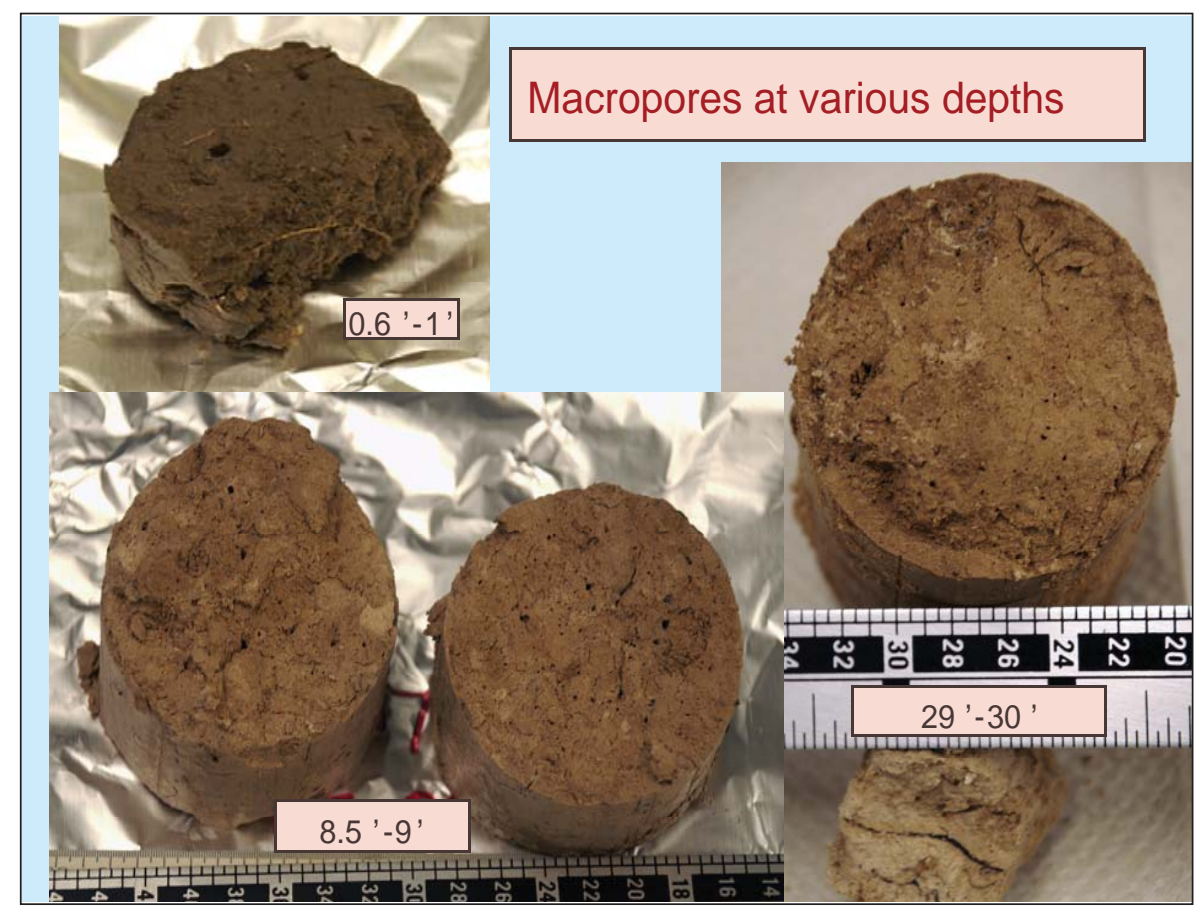

FIGURE 11-Soil cores at various depths from the study sites showing macropores. Numbers indicate depth in feet. (To convert to meters multiply value by 0.3048 .) The bottom right core picture shows a macropore lining with decaying organic material.
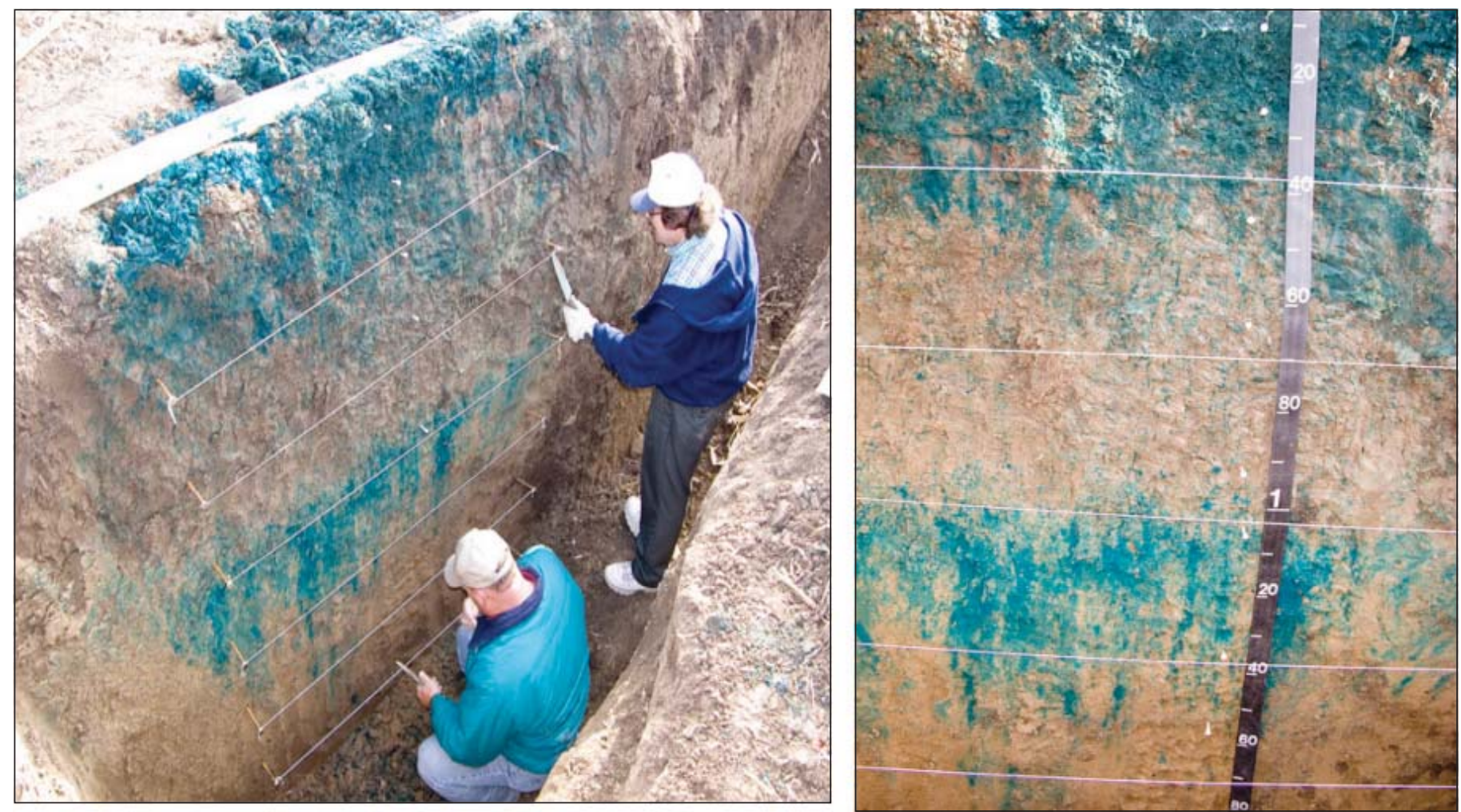

FIGURE 12-Uniform finger front from brilliant-blue dye-tracer experiment at site R8. The image on the right shows in more detail the dye moving through the inter-soil block structure spaces of the Bt horizon and accumulating below that blocky layer into numerous fingers. 


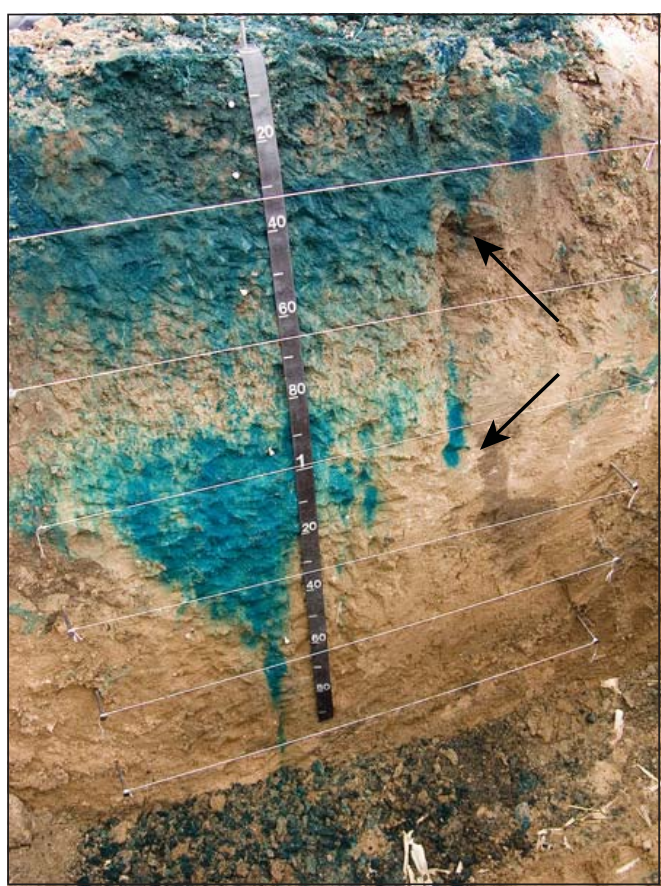

FIGURE 13-Funnel-front pattern from brilliant-blue dye-tracer experiment at site $\mathrm{N} 7$ and side finger formed along a decaying root channel (indicated by the two arrows).

\section{Sensitivity Analysis and RZWQM Macropore-Flow Impacts}

For the sensitivity analysis of hydraulic properties, the response variable considered was soil-water content, whereas for the sensitivity analysis of crop parameters, the response variable considered was soil nitrate-N.

For hydraulic parameters, bulk density, saturation water content $\left(\theta_{s}\right)$, and the Brooks and Corey parameters $\lambda$ and $\psi_{\text {a }}$ were the most sensitive (as can be seen in fig. A1 in Appendix A), whereas saturated hydraulic conductivity $\left(\mathrm{K}_{\mathrm{s}}\right)$ and residual water content $\left(\theta_{r}\right)$ were the least sensitive. Additional details on hydraulic- and crop-parameter sensitivity analyses for this study site are presented in Sophocleous et al. (2007).

Ahuja and Williams (1991) and Williams and Ahuja (2003) found that the soil-water-retention curves, as described by the Brooks and Corey equations, could be simply described by the pore-size-distribution index, $\lambda$. The importance of $\lambda$ was used for scaling water infiltration and redistribution (Kozak and Ahuja, 2005) and for scaling evaporation and transpiration across soil textures (Kozak et al., 2005). Because of the relatively high sensitivity of parameters $\theta_{s}$ and $\lambda$, both of which are fitted (as opposed to experimentally measured) parameters, we decided to use primarily the $\lambda$-parameter and secondarily the $\theta_{s}$ parameter to calibrate the RZWQM model. Therefore, these two parameters were varied by up to $25 \%$ of their originally estimated values to obtain the best fit between simulated and measured values of soil moisture. In a few instances the calibrated $\theta_{s}$ values, which should be considered the calibrated porosity values, were larger than the initially estimated porosity values. Because the porosity $(\varphi)$ estimates
$(\varphi=1-B D / P D)$, derived from the field-measured bulk density $(B D)$ and the particle density $(P D)$, in our case assumed equal to that of quartz $\left(2.65 \mathrm{~g} / \mathrm{cm}^{3}\right)$, contain considerable error, we did not restrict the $\theta_{s}$ values to be less than $\varphi$. The RZWQM2 uses $\theta_{s}$ values, not $\varphi$ values, in its numerical calculations. The calibrated $\theta_{s}$ and $\lambda$ values for the simulated soil layers are shown in table 3 .

With regard to macropore parameters, their sensitivity was relatively small. The most sensitive macropore parameters were the total macroporosity fraction and the average size of pore radii (as can be seen in fig. A2 in Appendix A). Macropore flow is generated only during heavy rainfall events in the model. For example, the rainfall events during June 10 and 12, 2005 (Julian days 161 and 163 in fig. 3), generated less than $2.8 \mathrm{~cm}$ of macropore soil-water flow at site N7. No other macropore flow-causing rainfall events occurred during the April to December 2005 simulation period for site N7, whereas a total of 11 rainfall events generated 5.8 $\mathrm{cm}$ of macropore flow for site R8 during the same period. During 2006, three rainfall events caused less than $0.4 \mathrm{~cm}$ of macropore soil-water flow, whereas nine rainfall events generated $6.9 \mathrm{~cm}$ of macropore flow for site R8 during 2006. Thus, the total April 2005 to December 2006 macropore flow for site $\mathrm{N} 7$ was $3.1 \mathrm{~cm}$, which represents approximately $3 \%$ of the total precipitation during that 2005-06 simulation period, whereas the simulated macropore flow for site $\mathrm{R} 8$ was more than $12.6 \mathrm{~cm}$, which represents $13.3 \%$ of total precipitation during that simulation period. This significant difference in macropore flow between the two sites is mainly related to the fact that the soil texture for R8 is generally more clayey than that for N7 (table 1), with the lower soil-infiltration capacity of the heavier-textured soil at site R8 creating more opportunities for macropore flow. Also the total $4.8-\mathrm{m}$ simulated depth for site R8 was appreciably smaller compared to the $10.8-\mathrm{m}$ simulated depth for site $\mathrm{N} 7$, resulting in an uneven soil-profile macropore comparison.

In a sensitivity analysis when we doubled the amount of rainfall for site N7 during the rainy days of the period May 24 to June 14, 2005 (Julian days 144 to 165 in fig. 3), the simulated macropore soil-water flow increased by more than four times. Macroporosity also had appreciable effect on $\mathrm{N}$ distribution (fig. 14). Figure 14a shows the simulated $\mathrm{N}$ distributions in the upper $3.5 \mathrm{~m}$ of the soil profile on the macropore-flow-causing rainy day of June 12, 2005 (Julian day 163 in fig. 3), with and without simulated macropores. Figure $14 \mathrm{~b}$ displays the same profile as fig. 14a, but with doubling the rain on all rainfall days across the May 24-June 14 period, including the rains of June 10 and 12, 2005. Because the presence of macropore flow led to increased $\mathrm{N}$ concentrations at greater depths, our simulation results suggest that high-intensity storm events can initiate macropore flow. In general, the higher the intensity and amount, the higher the generated macropore flow.

Although site R8 showed appreciable simulated macropore flow, RZWQM-simulated macropore flow for site N7 during the 2005-06 study period had no major impact on the results. We believe the reasons for such RZWQM results are the following: 
TABLE 3-Estimated soil physical properties for sites N7 and R8 by layer (in units employed in the RZWQM).

\begin{tabular}{|c|c|c|c|c|c|}
\hline Layer & Soil type & $\begin{array}{l}\text { Horizon depth } \\
\text { (cm) }\end{array}$ & $\begin{array}{c}\text { Air-entry (bubbling) } \\
\text { pressure head }\left(\psi_{\mathrm{a}}\right) \\
(\mathrm{cm})\end{array}$ & $\begin{array}{c}\text { Calibrated porosity } \\
\left(\begin{array}{c}\left.\boldsymbol{\theta}_{\mathbf{s}}\right) \\
\left(\mathrm{cm}^{3} / \mathrm{cm}^{3}\right)\end{array}\right. \\
\end{array}$ & $\begin{array}{c}\text { Calibrated pore size } \\
\text { distribution index }(\lambda) \\
\text { (dimensionless) }\end{array}$ \\
\hline \multicolumn{6}{|l|}{ Site N7 } \\
\hline 1 & Silty loam & $0-23$ & -26.28 & 0.467 & 0.204 \\
\hline 2 & Silty clay loam & $23-74$ & -17.53 & 0.527 & 0.122 \\
\hline 3 & Silty clay loam & $74-168$ & -36.77 & 0.486 & 0.169 \\
\hline 4 & Silty clay loam & $168-221$ & -113.64 & 0.425 & 0.253 \\
\hline 5 & Silty clay loam & $221-363$ & -34.36 & 0.518 & 0.189 \\
\hline 6 & Silty clay loam & $363-625$ & -48.54 & 0.436 & 0.199 \\
\hline 7 & Silty loam & $625-848$ & -156.25 & 0.445 & 0.364 \\
\hline 8 & Silty loam & $848-889$ & -98.21 & 0.431 & 0.267 \\
\hline 9 & Silty loam & $889-945$ & -40.61 & 0.414 & 0.300 \\
\hline 10 & Loam & $945-1079$ & -98.04 & 0.446 & 0.313 \\
\hline \multicolumn{6}{|l|}{ Site $R 8$} \\
\hline 1 & Silty clay loam & $0-16$ & -16.38 & 0.518 & 0.151 \\
\hline 2 & Silty clay loam & $16-29$ & -23.61 & 0.494 & 0.151 \\
\hline 3 & Silty clay loam & $29-50$ & -156.25 & 0.566 & 0.269 \\
\hline 4 & Silty clay & $50-68$ & -89.29 & 0.518 & 0.181 \\
\hline 5 & Silty clay loam & $68-90$ & -84.03 & 0.500 & 0.216 \\
\hline 6 & Silty clay loam & $90-140$ & -67.57 & 0.513 & 0.217 \\
\hline 7 & Silty clay loam & $140-260$ & -52.63 & 0.485 & 0.209 \\
\hline 8 & Silty clay loam & $260-300$ & -131.58 & 0.456 & 0.238 \\
\hline 9 & Clay loam & $300-410$ & -109.89 & 0.507 & 0.314 \\
\hline 10 & Silty clay loam & $410-484$ & -65.36 & 0.525 & 0.246 \\
\hline
\end{tabular}
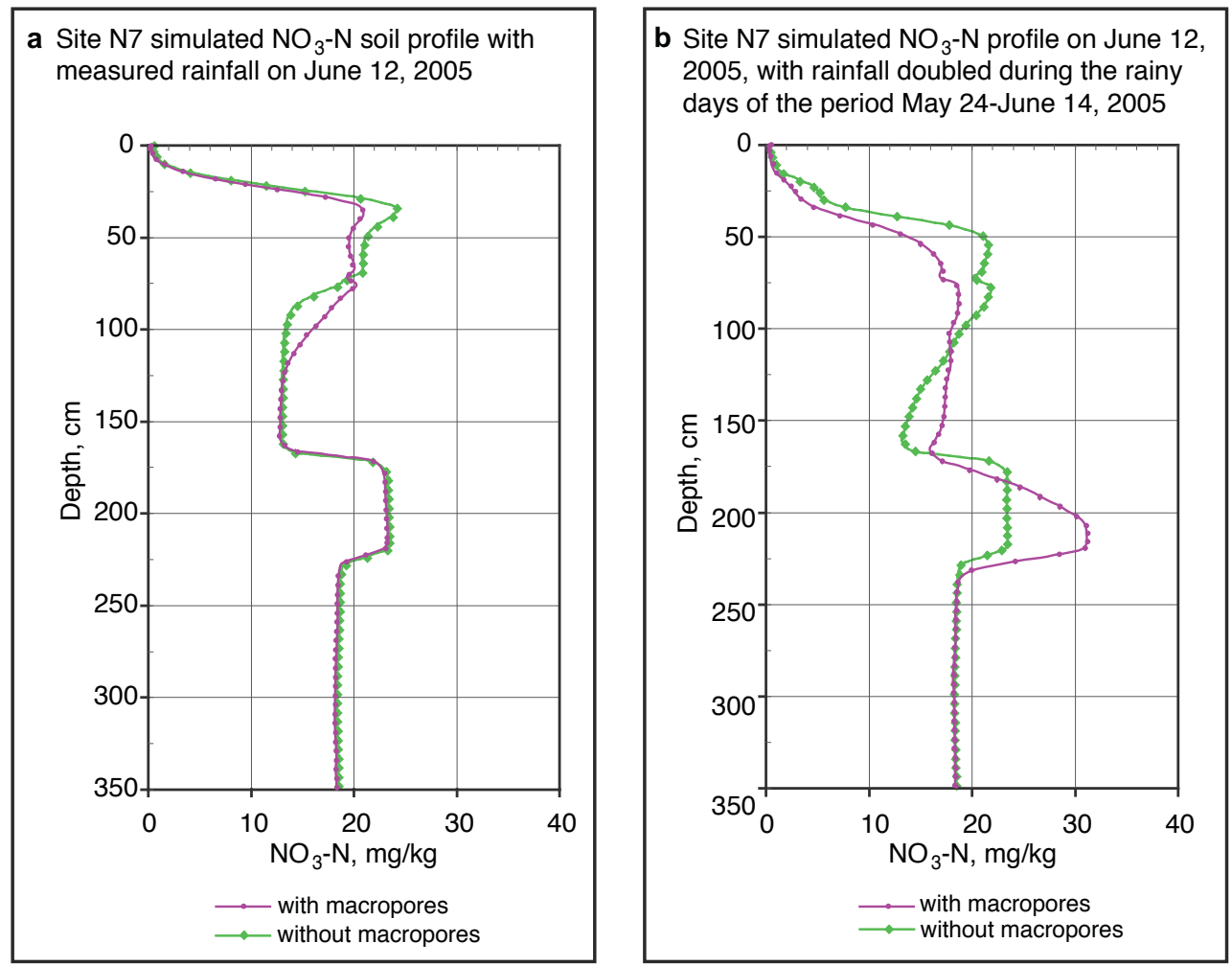

FIGURE 14-Simulated nitrogen profiles for the upper $3.5 \mathrm{~m}$ of soil at site N7 with and without macropores for (a) the observed June 12 , 2005, rainfall distribution, and (b) June 12, 2005, after doubling the observed rainfall during the rainy days of the period of May 24 to June 14, 2005. 
1. The RZWQM generates macropore flow only when excess water generated at the soil surface does not infiltrate into the soil matrix. This happens when the rate of application of water (irrigation or rain) is greater than the infiltration rate in the soil. The rate of wastewater sprinkler application was relatively small, about $7 \mathrm{~mm} /$ day, as mentioned previously. This application rate is low enough that all the water will infiltrate into the soil matrix, and no macropore flow is generated, even though macropores are present. Only two rainfall events during the April to December 2005 simulation period exceeded the infiltration capacity of the soil at site N7, whereas at the more clayey site R8, as previously mentioned, 11 rainfall events exceeded its infiltration capacity during the same period. If the irrigation wastewater were ponded (as in flood irrigation), the results would have been more macropore flow as actually observed with the brilliant-blue-dye experiments. To further prove this point, we re-ran the RZWQM model using the same conditions in all respects except for the method of irrigation, which was changed from sprinkler to flood irrigation. Using flood irrigation, macropore-flow increased tremendously for site N7, from a total of $3.1 \mathrm{~cm}$ with sprinkler irrigation to $48.8 \mathrm{~cm}$ with flood irrigation during the 2005-06 simulation period.

2. The model comparisons between the measured and double the measured rain intensities for site N7 show only modest macropore-flow increases. Nitrate is a non-adsorbed mobile anion. It is not kept near the soil surface by adsorption as other chemicals, such as ammonium ion or brilliant-blue dye will be. If it were adsorbed, the higher-intensity rains would probably cause more nitrate flow through macropores. Higher rain intensity after irrigation with nitrate-laden wastewater in RZWQM simulations is not going to make much difference for nitrate, as it has already moved deeper into the soil. The macropore flow in RZWQM only carries chemical constituents from the surface soil with overland flow (excess water generated at the surface due to infiltration being less than the rainfall or irrigation-application rate).

3. A conceptual deficiency in the RZWQM is the following: the RZWQM does not allow macropore flow from soil water ponded over a low-hydraulicconductivity (impeding) soil horizon at some depth in the soil profile; it only allows macropore flow from ground-surface irrigation or rainfall rates that exceed the infiltration capacity of the surface soil.

Despite the above-mentioned RZWQM conceptual macropore deficiencies, we decided to retain the macropore option in our simulations because of our experimental observations indicating the existence of macropores throughout the soil profile and the occurrence of measurable nitrate-N at depth in the vadose zone. Overall, the major hydrologic effect of introducing macropores in the RZWQM model is to reduce surface runoff.

With regard to organic-matter/nitrate cycling parameters, the aerobic heterotroph microbial population (that is organisms capable of deriving carbon and energy from organic compounds, and growing only in the presence of molecular oxygen) showed greater sensitivity than the transition and fast humus pool sizes (as shown in fig. A3 in Appendix A). Finally, for corn (CERES-Maize) parameters, the P1 and P5 were the most sensitive of the physiological parameters, followed (in decreasing order of sensitivity) by the G2 and G3 growth parameters (as shown in fig. A4 in Appendix A). P2 was the least sensitive of the physiological parameters. (All these parameters have been briefly explained previously in the subsection on Model-Calibration Procedures in the Methodology section.) The calibrated CERES-Maize parameters are shown in table 4.

TABLE 4-Calibrated crop parameters used as input to RZWQM2 for CERES-Maize.

\begin{tabular}{llc}
\hline & \multicolumn{1}{c}{ Maize parameter } & Calibrated values \\
\hline P1 & $\begin{array}{l}\text { Thermal time from seedling emergence to the end of juvenile phase during } \\
\text { which the plants are not responsive to changes in photoperiod (degree days). }\end{array}$ & 245 \\
P2 & $\begin{array}{l}\text { Extent to which development is delayed for each hour increase in photoperiod } \\
\text { above the longest photoperiod at which development is at maximum rate, } \\
\text { which is considered to be 12.5 hours (days). }\end{array}$ & 0.52 \\
& Thermal time from silking to physiological maturity (degree days). & 990 \\
G2 & Maximum possible number of kernels per plant. & 1100 \\
G3 & Grain-filling rate during the linear grain-filling stage and under optimum & 10.0 \\
& conditions (mg/day). & 38.9 \\
\hline
\end{tabular}




\section{RZWQM2 Model Simulation and Evaluation}

Both wastewater-irrigation sites, N7 and R8, were simulated starting from the spring of 2005 and finishing at the end of 2006 using the RZWQM (Sophocleous et al., 2007). Both sites were planted with corn.

The simulated and observed soil water for the various individual layers for sites N7 (total simulation depth: 10.8 $\mathrm{m}$ ) and R8 (total simulation depth: $4.8 \mathrm{~m}$ ) are shown in figs. 15 and 16, respectively, for the April to December 2005
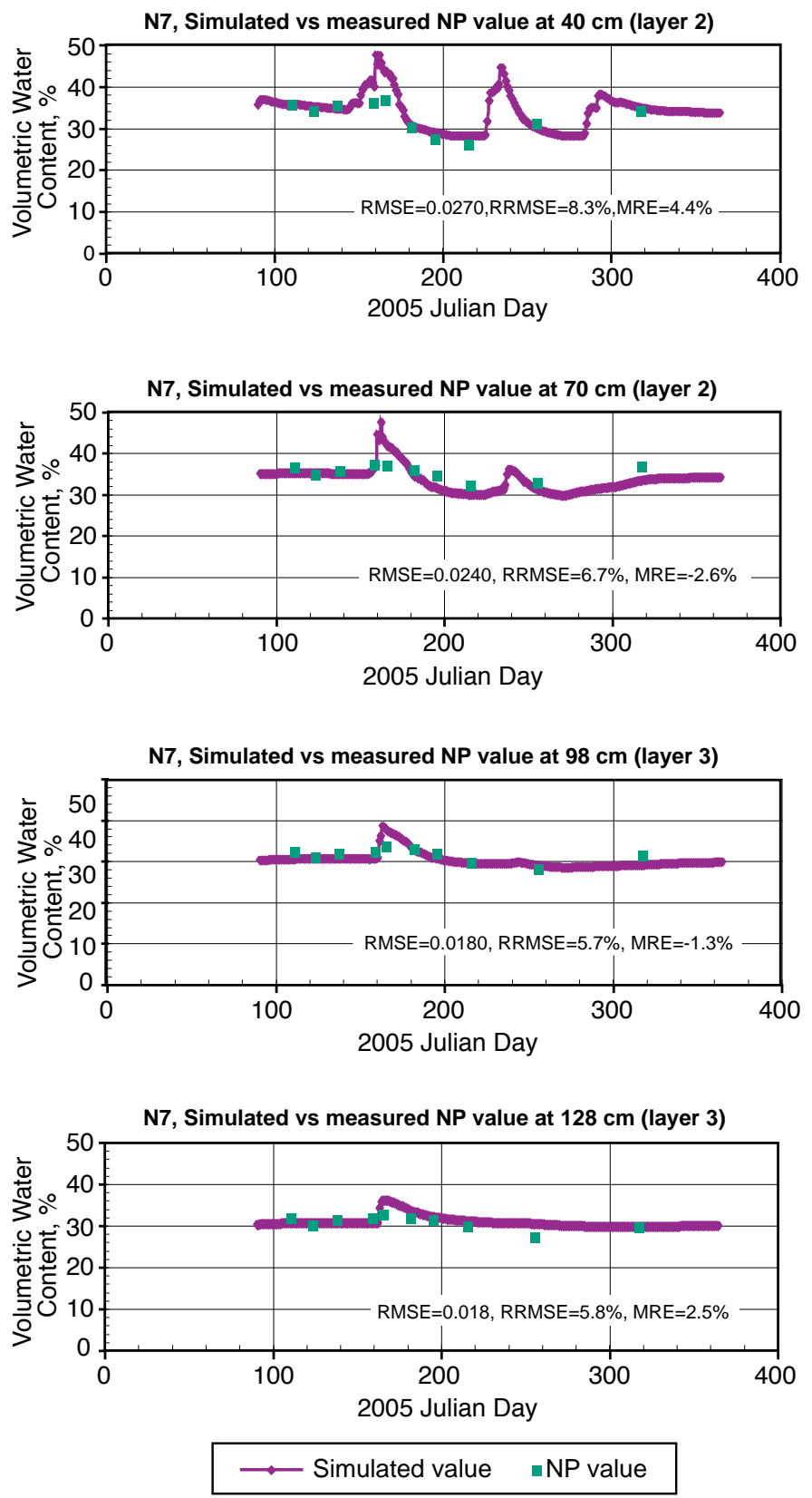

simulation period. Although for the upper layers of the soil in both sites the RRMSE and other error measures were relatively high, they improved with soil depth, as shown in the data for the deeper layers. Using the 2005 calibration parameters, the simulated 2006 planting season for sites N7 and R8 are shown in figs. 17 and 18, respectively, along with the three statistics (eqns. 5-7). The model seems to be satisfactorily predicting measured values, although additional measured data may have further improved this calibration.

Regarding simulated soil nitrate-N, only results from site $\mathrm{N} 7$ will be highlighted from here onwards, for which we had relatively more detailed hydraulic-property data for
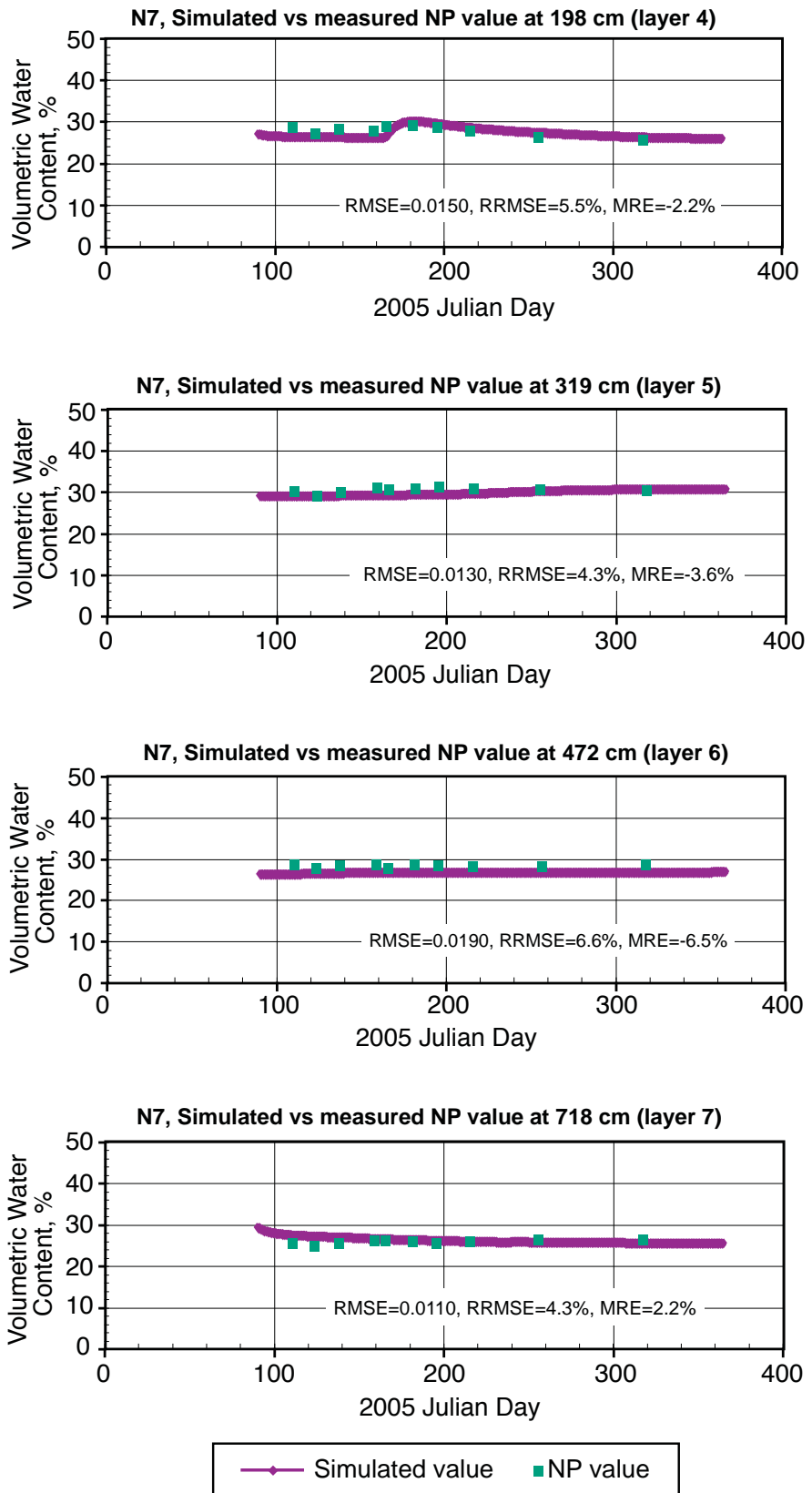

FIGURE 15-Comparison of model-simulated and field-measured soil-water contents at various soil depths for site N7 during the 2005 calibration period. Three statistical indices, root mean square error (RMSE), relative RMSE (RRMSE), and mean relative error (MRE), all defined in the text, are used to quantify the goodness of fit of model parameterization. NP stands for neutron probe-measured soilwater content. 
a deeper vadose-zone profile analysis resulting in generally better simulation results than those for site $\mathrm{R} 8$, as shown in Sophocleous et al. (2009). The simulated and measured soil nitrate-N profiles in the fall of 2005 in site N7, which was planted in corn in April and harvested at the end of September, are shown in fig. 19 for both the 2005 calibration year (a) and the 2006 prediction year ( $\mathrm{b}$ and $\mathrm{c})$. The model approximated the main patterns of the nitrate-depth profile relatively well, but not the observed detailed nitrate patterns in the soil profile. The total measured soil nitrate- $\mathrm{N}$ in the 10.8 -m modeled soil profile during the post-harvest or pre-planting core-sampling dates of November 10, 2005, April 18, 2006, and November 7, 2006, was $1,225,1,393$, and $1,389 \mathrm{~kg} / \mathrm{ha}$, respectively, whereas the simulated soil-profile nitrate-N during the same dates was $1,450,1,576$, and $1,821 \mathrm{~kg} / \mathrm{ha}$, respectively, thus consistently overestimating the measured profile soil nitrate by 13 to $31 \%$. This overestimation is consistent with soil nitrate over-prediction during corn years observed by Malone et al. (2001) in evaluating numerous studies employing the RZWQM model. In a comprehensive study of the fate of $\mathrm{N}$ in a field soil-crop environment in the Mediterranean region, Cameira et al. (2007) found that the prediction of residual nitrate- $\mathrm{N}$ in the soil, after crop harvest, presented errors ranging from 19 to $38 \%$ using RZWQM. Our results show the RZWQM is capable of simulating generally complex field conditions with acceptable accuracy.
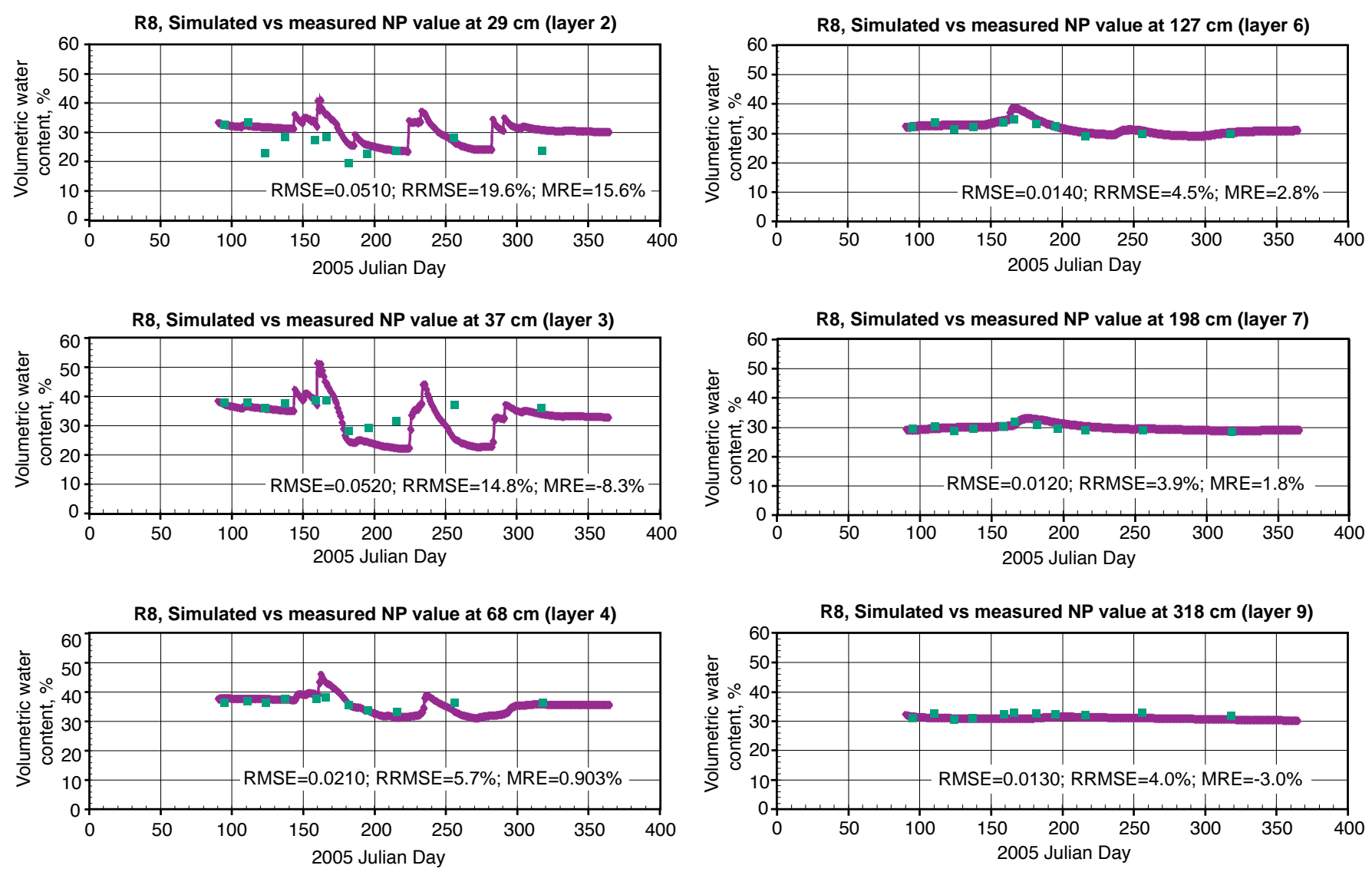

R8, Simulated vs measured NP value at $97 \mathrm{~cm}$ (layer 5)
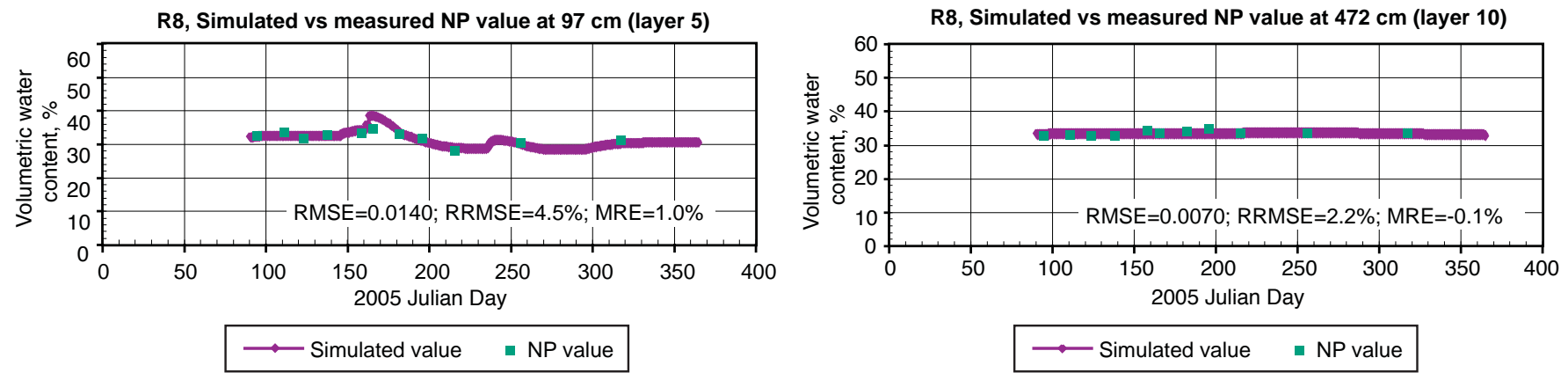

FIGURE 16-Comparison of model-simulated and field-measured soil-water contents at various soil depths for site R8 during the 2005 calibration period. Three statistical indices, root mean square error (RMSE), relative RMSE (RRMSE), and mean relative error (MRE), all defined in the text, are used to quantify the goodness of fit of model parameterization. NP stands for neutron probe-measured soilwater content. 
Besides the measured soil-profile water content and soil nitrate- $\mathrm{N}$ values, the third model evaluation check employed was the harvested corn-grain yield, which for site N7 for 2005 was $14,247 \mathrm{~kg} / \mathrm{ha}$ and for 2006 was $12,553 \mathrm{~kg} / \mathrm{ha}$. The simulated corn-grain yields were $15,384 \mathrm{~kg} / \mathrm{ha}$ and $11,626 \mathrm{~kg} /$ ha for 2005 and 2006, respectively, in both cases within less than $8 \%$ of measured values.
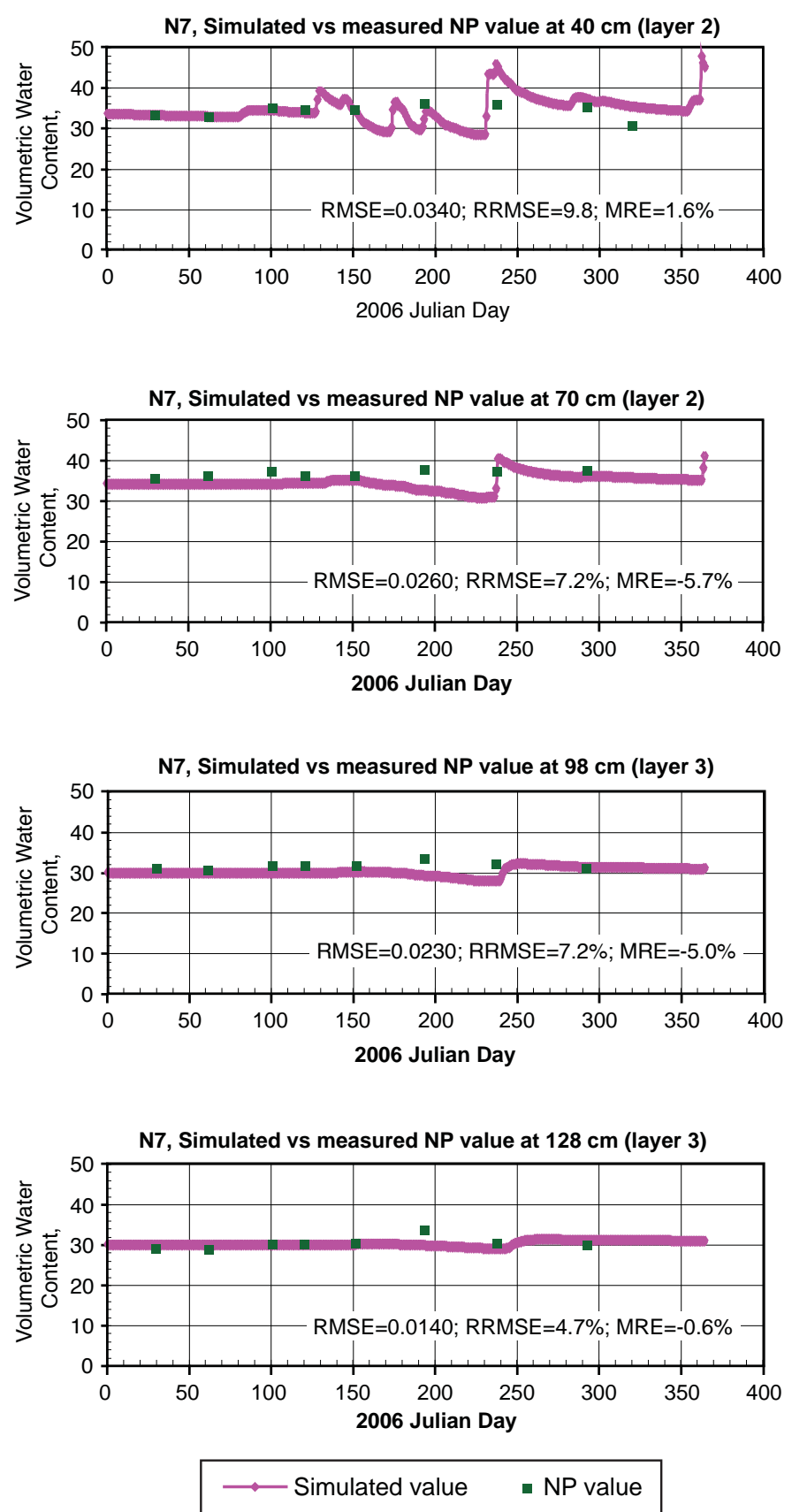

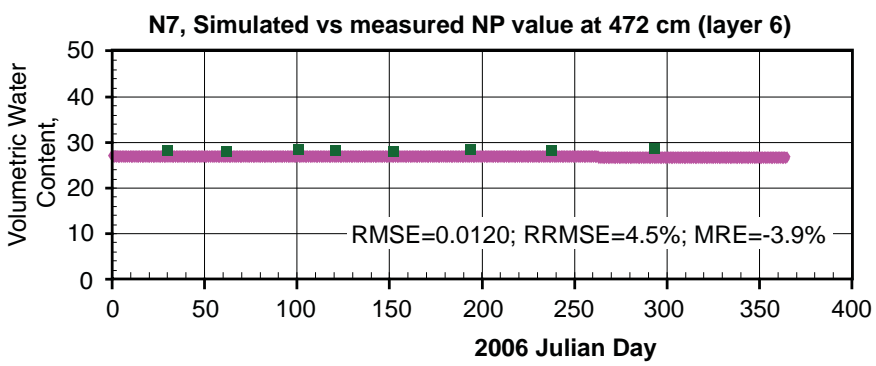

\section{Nitrogen-Use Efficiency, Nitrogen Budget, and Management Scenarios}

Once an agricultural system is adequately calibrated and tested, it has the potential for use in evaluation of alternative crop-soil management practices for their production potential and impact on the environment (Hu et al., 2006).
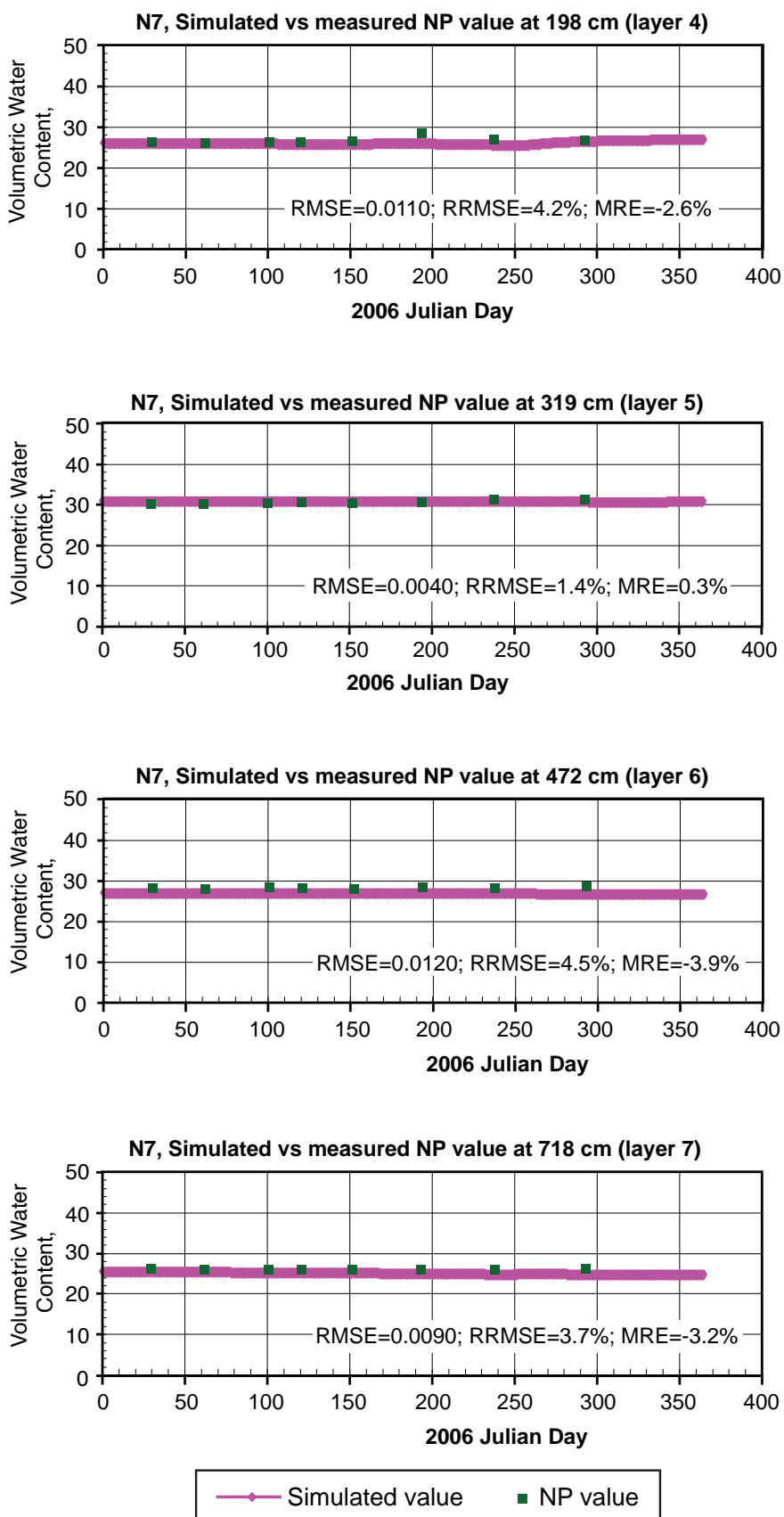

FIGURE 17-Comparison of model-simulated and field-measured soil-water contents at various soil depths for site N7 during the 2006 prediction period. Three statistical indices, root mean square error (RMSE), relative RMSE (RRMSE), and mean relative error (MRE), all defined in the text, are used to quantify the goodness of fit of model parameterization. NP stands for neutron probe-measured soil-water content. 
Historical and current sampling of $\mathrm{N}$ in the soil at the wastewater-irrigated sites show increased accumulation of inorganic $\mathrm{N}$ in the soil profile with time (see also figs. 8 and 10 ), suggesting the inorganic $\mathrm{N}$ remaining in the soil at harvest was not taken up completely by the subsequent crop. This residual $\mathrm{N}$ is subject to leaching to ground water when rainfall, especially of high intensity that enhances macropore flow, occurs between crop seasons. Numerical simulations indicated consistent increases in $\mathrm{N}$ losses due to denitrification, volatilization, and deep seepage as the $\mathrm{N}$-application rate increased (table 5).
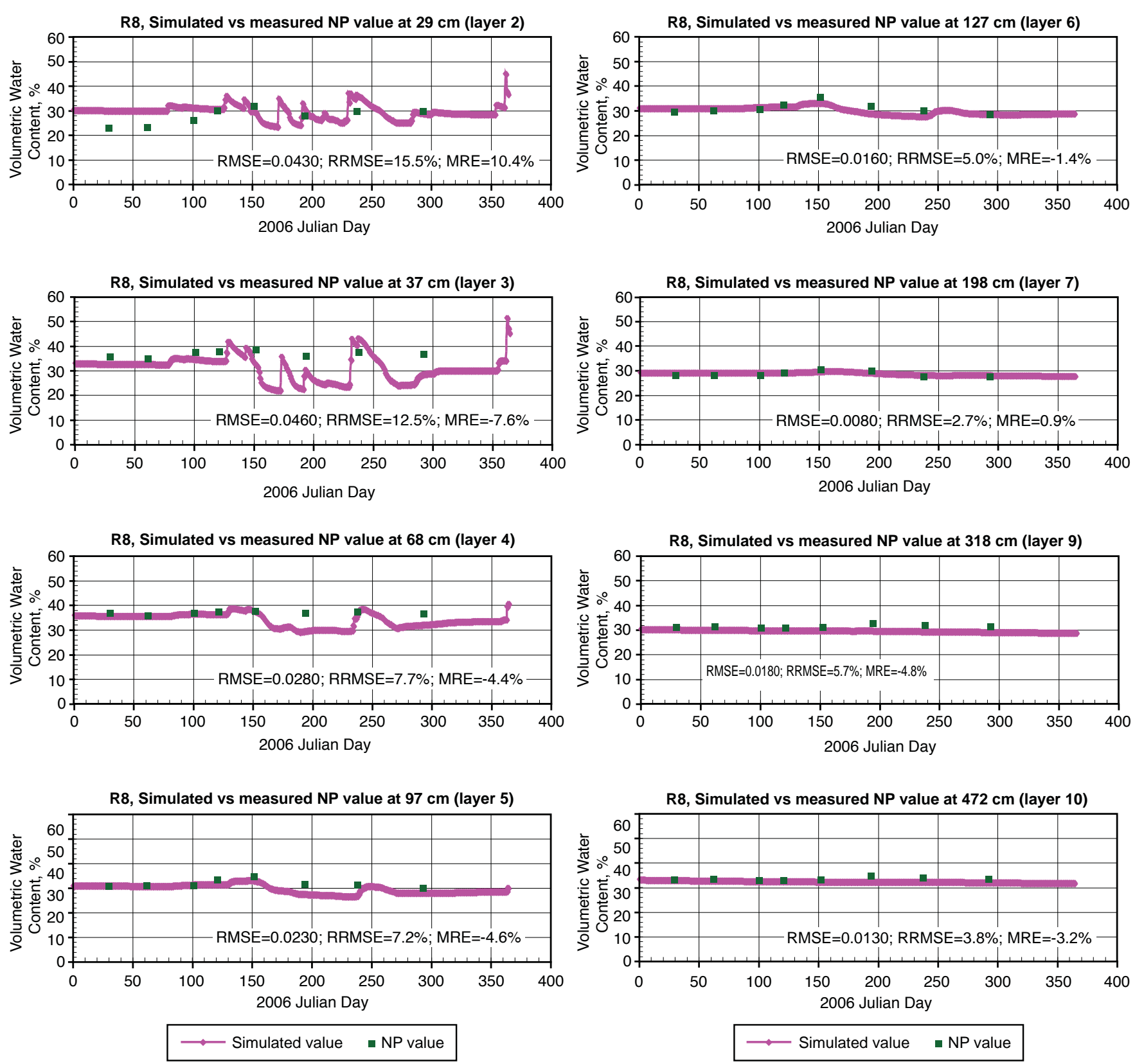

FIGURE 18-Comparison of model-simulated and field-measured soil-water contents at various soil depths for site R8 during the 2006 prediction period. Three statistical indices, root mean square error (RMSE), relative RMSE (RRMSE), and mean relative error (MRE), all defined in the text, are used to quantify the goodness of fit of model parameterization. NP stands for neutron probe-measured soil-water content. 
Treated Wastewater and Nitrate Transport Beneath Irrigated Fields near Dodge City, Kansas, Sophocleous et al.

TABLE 5-Nitrogen inputs and losses predicted by RZWQM2 for the 2005 and 2006 crop seasons for site N7 for current, 50\%, and 40\% levels of N-fertilization rates and various levels of irrigation reduction through the LEPA system.

\begin{tabular}{|c|c|c|c|c|c|c|c|c|c|c|c|c|c|c|c|c|}
\hline \multirow{2}{*}{$\begin{array}{r}\text { Description of method } \\
2005\end{array}$} & \multicolumn{7}{|c|}{ Total N Input (kg/ha) } & \multicolumn{8}{|c|}{ Total N losses (kg/ha) } & \multirow[b]{2}{*}{$\begin{array}{l}\text { NUEc }^{c} \\
\%\end{array}$} \\
\hline & $\begin{array}{l}\text { Crop yield } \\
\text { (kg/ha) }\end{array}$ & $\begin{array}{l}\text { Percent } \\
\text { change in } \\
\text { crop yield }\end{array}$ & $\begin{array}{l}\text { Storage } \\
\text { (10.8m- } \\
\text { profile) }\end{array}$ & Rain & $\begin{array}{l}\text { Ferti- } \\
\text { gation }^{b}\end{array}$ & $\begin{array}{l}\text { Mineral- } \\
\text { ization }\end{array}$ & $\begin{array}{l}\text { Percent } \\
\text { change in } \\
\text { mineral- } \\
\text { ization }\end{array}$ & $\begin{array}{l}\text { Plant } \\
\text { uptake }\end{array}$ & $\begin{array}{l}\text { Percent } \\
\text { change } \\
\text { in plant } \\
\text { uptake }\end{array}$ & $\begin{array}{l}\text { Deep } \\
\text { seepage }\end{array}$ & $\begin{array}{l}\text { Percent } \\
\text { change } \\
\text { in deep } \\
\text { seepage }\end{array}$ & $\begin{array}{l}\text { Denitri- } \\
\text { fication }\end{array}$ & $\begin{array}{l}\text { Percent } \\
\text { change in } \\
\text { denitri- } \\
\text { fication }\end{array}$ & Volatilization & $\begin{array}{l}\text { Percent } \\
\text { change in } \\
\text { volatilization }\end{array}$ & \\
\hline 1. Full rate irrigation, full rate $\mathrm{N}$ fertilization ${ }^{b}$ & 15384 & --.-- & 1389.8 & 9.4 & 427.4 & 41.2 & ---- & 360.8 & -ב-ב-ב-ב & 1.8 & --.-- & 15.0 & ---- & 12.6 & --.-- & 42.20 \\
\hline 2. Full rate irrigation, $50 \% \mathrm{~N}$ fertilization & 15547 & 1.06 & 1270.9 & 9.4 & 214.4 & 41.3 & 0.18 & 364.0 & 0.87 & 1.8 & 0.01 & 4.1 & -72.93 & 2.6 & -79.63 & 85.59 \\
\hline 3. Full rate irrigation, $40 \% \mathrm{~N}$ fertilization & 15531 & 0.96 & 1258.9 & 9.4 & 170.4 & 40.1 & -0.57 & 340.1 & -5.74 & 1.8 & 0.02 & 3.7 & -75.62 & 1.5 & -88.09 & 93.70 \\
\hline 4. Full rate irrigation, zero fertilization & 11005 & -28.46 & 1251.6 & 9.4 & -.----- & 40.9 & -0.69 & 180.5 & -49.99 & 1.8 & -0.07 & 3.2 & -78.45 & 0.0 & -99.97 & -.----- \\
\hline 5. $88 \%$ irrigation, full rate $\mathrm{N}$ fertilization & 13654 & -11.25 & 1407.9 & 9.4 & 427.4 & 42.1 & 2.02 & 328.7 & -8.92 & 1.8 & 0.37 & 17.3 & 15.18 & 13.1 & 4.34 & 35.04 \\
\hline 6. $88 \%$ irrigation, $50 \% \mathrm{~N}$ fertilization & 14045 & -8.70 & 1285.6 & 9.4 & 214.4 & 42.3 & 2.73 & 337.7 & -6.42 & 1.8 & 0.38 & 5.1 & -66.35 & 2.7 & -78.54 & 74.06 \\
\hline 7. $88 \%$ irrigation, $40 \% \mathrm{~N}$ fertilization & 14090 & -8.41 & 1263.6 & 9.4 & 170.4 & 42.0 & 1.91 & 332.1 & -7.95 & 1.8 & 0.38 & 3.8 & -74.96 & 1.6 & -87.43 & 89.94 \\
\hline 8. 88\% irrigation, zero fertilization & 10541 & -31.48 & 1252.5 & 9.4 & ---- & 41.8 & 1.61 & 178.9 & -50.43 & 1.8 & 0.51 & 3.23 & -78.5 & 0.0 & -99.97 & --.-- \\
\hline 10. $75 \%$ irrigation, full rate $\mathrm{N}$ fertilization & 11834 & -23.08 & 1427.5 & 9.3 & 427.4 & 42.8 & 3.87 & 294.5 & -18.39 & 1.8 & -0.15 & 19.5 & 29.82 & 13.5 & 7.71 & 27.68 \\
\hline 11. $75 \%$ irrigation, $50 \% \mathrm{~N}$ fertilization & 11993 & -22.04 & 1307.0 & 9.3 & 214.4 & 43.1 & 4.71 & 299.3 & -17.04 & 1.8 & -0.14 & 6.9 & -54.21 & 2.8 & -77.63 & 56.04 \\
\hline 12. $75 \%$ irrigation, $40 \% \mathrm{~N}$ fertilization & 12132 & -21.14 & 1280.8 & 9.3 & 170.4 & 43.2 & 4.82 & 302.2 & -16.26 & 1.8 & -0.15 & 4.7 & -68.56 & 1.7 & -86.71 & 72.17 \\
\hline 13. $75 \%$ irrigation, zero fertilization & 9866 & -35.87 & 1252.5 & 9.3 & ----- & 43.0 & 4.49 & 179.2 & -50.34 & 1.8 & -0.19 & 3.2 & -78.60 & 0.0 & -99.97 & ----- \\
\hline 14. $50 \%$ irrigation, full rate $\mathrm{N}$ fertilization & 8005 & -47.97 & 1471.9 & 9.3 & 427.4 & 43.7 & 6.03 & 217.4 & -39.75 & 1.7 & -1.16 & 24.4 & 62.23 & 15.2 & 20.76 & 8.79 \\
\hline 15. 50\% irrigation, $50 \% \mathrm{~N}$ fertilization & 8056 & -47.63 & 1350.8 & 9.3 & 214.4 & 44.3 & 7.57 & 220.9 & -38.78 & 1.7 & -1.21 & 11.3 & -25.06 & 3.2 & -74.72 & 19.14 \\
\hline 16. $50 \%$ irrigation, $40 \% \mathrm{~N}$ fertilization & 8128 & -47.17 & 1325.2 & 9.3 & 170.4 & 44.4 & 7.78 & 222.8 & -38.24 & 1.7 & -1.21 & 8.6 & -43.00 & 1.9 & -84.93 & 25.23 \\
\hline 17. $50 \%$ irrigation, zero fertilization & 7660 & -50.21 & 1253.7 & 9.3 & -.---- & 44.9 & 8.91 & 179.8 & -50.16 & 1.7 & -1.12 & 3.2 & -78.58 & 0.0 & -99.97 & --- \\
\hline \multicolumn{16}{|c|}{${ }^{\mathrm{a}}$ Full rate of 2005-season irrigation $=48.55 \mathrm{~cm} \quad{ }^{\mathrm{b}}$ Full rate of 2005-season fertigation $=427.4 \mathrm{~kg} / \mathrm{ha} \quad{ }^{\mathrm{c}}$ Nitrogen-Use Efficiency } & \\
\hline Description of method & \multicolumn{7}{|c|}{ Total N Input (kg/ha) } & \multicolumn{8}{|c|}{ Total N losses (kg/ha) } & \\
\hline 2006 & $\begin{array}{l}\text { Crop yield } \\
\text { (kg/ha) }\end{array}$ & $\begin{array}{l}\text { Percent } \\
\text { change } \\
\text { in crop } \\
\text { yield }\end{array}$ & $\begin{array}{l}\text { Storage } \\
(10.8 \mathrm{~m}- \\
\text { profile) }\end{array}$ & Rain & $\begin{array}{l}\text { Ferti- } \\
\text { gatione }\end{array}$ & $\begin{array}{l}\text { Mineral- } \\
\text { ization }\end{array}$ & $\begin{array}{l}\text { Percent } \\
\text { change in } \\
\text { mineral- } \\
\text { ization }\end{array}$ & $\begin{array}{l}\text { Plant } \\
\text { uptake }\end{array}$ & $\begin{array}{l}\text { Percent } \\
\text { change } \\
\text { in plant } \\
\text { uptake }\end{array}$ & $\begin{array}{l}\text { Deep } \\
\text { seepage }\end{array}$ & $\begin{array}{l}\text { Percent } \\
\text { change } \\
\text { in deep } \\
\text { seepage }\end{array}$ & $\begin{array}{l}\text { Denitri- } \\
\text { fication }\end{array}$ & $\begin{array}{l}\text { Percent } \\
\text { change in } \\
\text { denitri- } \\
\text { fication }\end{array}$ & Volatilization & $\begin{array}{l}\text { Percent } \\
\text { change in } \\
\text { volatilization }\end{array}$ & $\begin{array}{l}\text { NUE }^{r} \\
\%\end{array}$ \\
\hline 1. Full rate irrigationd, full rate $\mathrm{N}$ fertilization & 11626 & --.-- & 1688.9 & 11.4 & 520.7 & 66.2 & (----- & 299.6 & ------ & 4.1 & 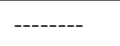 & 109.1 & -------- & 24.1 & ------- & 38.93 \\
\hline 2. Full rate irrigation, $50 \% \mathrm{~N}$ fertilization & 11898 & 2.34 & 1424.3 & 11.4 & 260.7 & 63.1 & -4.66 & 295.9 & -1.23 & 4.0 & -0.60 & 12.9 & -88.13 & 4.7 & -80.34 & 76.35 \\
\hline 3. Full rate irrigation, $40 \% \mathrm{~N}$ fertilization & 11823 & 1.69 & 1389.7 & 11.4 & 207.9 & 59.2 & -10.50 & 286.1 & -4.48 & 4.0 & -0.78 & 6.0 & -94.46 & 2.8 & -88.46 & 91.06 \\
\hline 4. Full rate irrigation, zero fertilization & 5618 & -51.68 & 1374.7 & 11.4 & ------ & 45.4 & -31.43 & 96.8 & -67.67 & 4.0 & -1.24 & 2.4 & -97.76 & 0.0 & -100.0 & -.-- \\
\hline 5. $88 \%$ irrigation, full rate $\mathrm{N}$ fertilization & 10068 & -13.4 & 1731.2 & 11.4 & 520.7 & 66.6 & 0.67 & 267.6 & -10.68 & 4.1 & 0.75 & 122.5 & 12.24 & 25.3 & 5.07 & 32.82 \\
\hline 6. $88 \%$ irrigation, $50 \% \mathrm{~N}$ fertilization & 10263 & -11.72 & 1457.4 & 11.4 & 260.7 & 65.2 & -1.46 & 270.8 & -9.61 & 4.1 & 0.14 & 20.4 & -81.28 & 5.2 & -78.64 & 66.79 \\
\hline 7. $88 \%$ irrigation, $40 \% \mathrm{~N}$ fertilization & 10581 & -8.99 & 1409.5 & 11.4 & 207.9 & 61.0 & -7.81 & 264.0 & -11.87 & 4.1 & -0.02 & 8.5 & -92.24 & 3.0 & -87.40 & 80.49 \\
\hline 8. $88 \%$ irrigation, zero fertilization & 5725 & -50.76 & 1379.5 & 11.4 & ----- & 47.8 & -27.84 & 96.7 & -67.73 & 4.0 & -0.57 & 2.6 & -97.62 & 0.0 & -100.0 & ----- \\
\hline $10.75 \%$ irrigation, full rate $\mathrm{N}$ fertilization & 8439 & -27.41 & 1776.9 & 11.4 & 520.7 & 66.3 & 0.17 & 233.7 & -21.97 & 4.1 & 1.36 & 135.7 & 24.38 & 27.0 & 11.89 & 26.40 \\
\hline 11. $75 \%$ irrigation, $50 \% \mathrm{~N}$ fertilization & 8720 & -25.00 & 1504.6 & 11.4 & 260.7 & 65.9 & -0.48 & 240.7 & -19.64 & 4.1 & 0.78 & 30.5 & -72.08 & 5.8 & -75.76 & 55.41 \\
\hline 12. $75 \%$ irrigation, $40 \% \mathrm{~N}$ fertilization & 8826 & -24.08 & 1448.7 & 11.4 & 207.9 & 64.3 & -2.80 & 237.7 & -20.66 & 4.1 & 0.67 & 15.2 & -86.09 & 3.4 & -86.11 & 68.02 \\
\hline 13. $75 \%$ irrigation, zero fertilization & 5742 & -50.61 & 1383.0 & 11.4 & -.----- & 48.8 & -26.32 & 96.3 & -67.86 & 4.1 & 0.19 & 2.7 & -97.55 & 0.0 & -100.0 & ------ \\
\hline 14. $50 \%$ irrigation, full rate $\mathrm{N}$ fertilization & 6817 & -41.36 & 1874.6 & 11.4 & 520.7 & 63.7 & -3.83 & 185.0 & -38.26 & 4.2 & 3.62 & 143.7 & 31.63 & 30.9 & 28.13 & 16.70 \\
\hline 15. 50\% irrigation, $50 \% \mathrm{~N}$ fertilization & 6754 & -41.91 & 1607.1 & 11.4 & 260.7 & 64.1 & -3.20 & 183.1 & -38.87 & 4.2 & 3.08 & 50.5 & -53.68 & 6.8 & -71.91 & 32.65 \\
\hline 16. $50 \%$ irrigation, $40 \% \mathrm{~N}$ fertilization & 6892 & -40.72 & 1547.7 & 11.4 & 207.9 & 63.6 & -3.97 & 185.1 & -38.21 & 4.2 & 2.97 & 31.6 & -71.07 & 4.1 & -83.02 & 41.90 \\
\hline 17. $50 \%$ irrigation, zero fertilization & 5645 & -51.45 & 1391.1 & 11.4 & ----- & 52.9 & -20.08 & 98.0 & -67.29 & 4.2 & 2.46 & 2.7 & -97.56 & 0.0 & -100.0 & ------ \\
\hline
\end{tabular}

$\frac{{ }^{\mathrm{d}} \text { Full rate of 2006-season irrigation }=51.48 \mathrm{~cm} \text { ' } \mathrm{F} \text { Full rate of 2006-season fertigation }=520.7 \mathrm{~kg} / \mathrm{ha}{ }^{\mathrm{f}} \text { Nitrogen-Use Efficiency }}{\text { Current Research in Earth Sciences, Bulletin 258, part } 1 \text { (http://www.kgs.ku.edu/Current/2010/Sophocleous/index.html) }}$ 

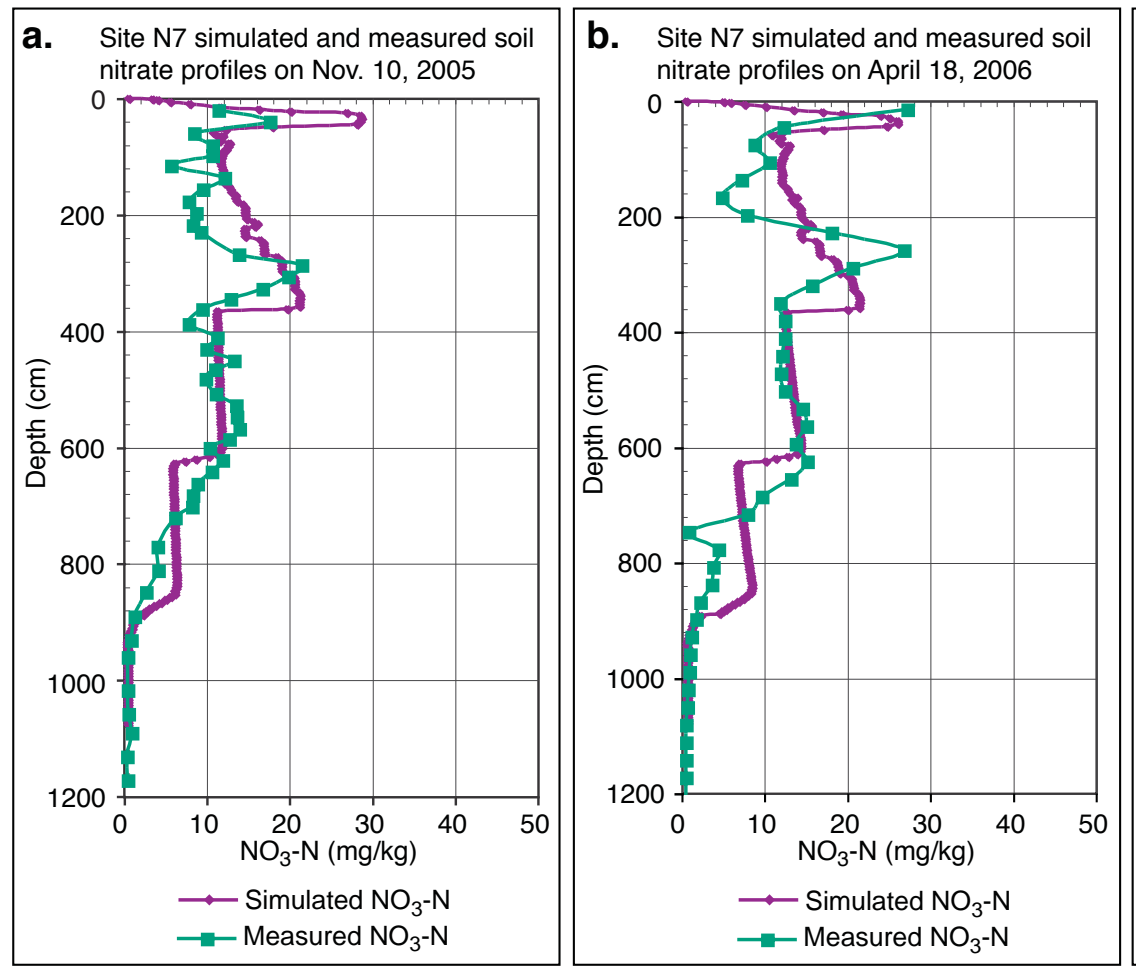

C. Site $\mathrm{N} 7$ simulated and measured soil nitrate profiles on Nov. 7, 2006

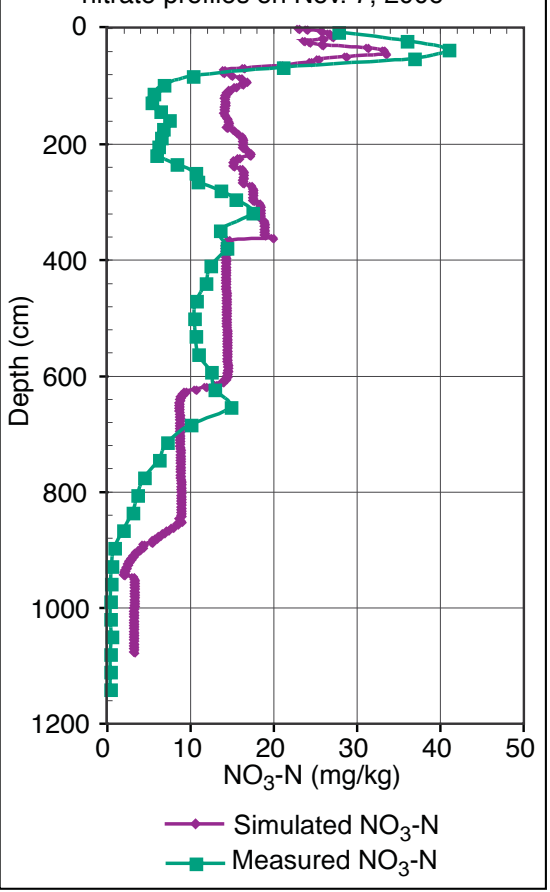

FIGURE 19-Measured and simulated soil nitrate-N profiles at site N7 (simulated depth 1,080 cm) during the soil-sampling dates of (a) November 10, 2005, (b) April 18, 2006, and (c) November 7, 2006.

effluent with additional, secondary sources from dead roots and incorporated residue, and the major losses of applied $\mathrm{N}$ are from plant uptake, with minor losses due to volatilization, denitrification, and deep seepage (table 5). Mineralization is the major transformation of $\mathrm{N}$, followed by immobilization.

Large amounts of nitrate exist in the unsaturated soil profile (figs. 8 and 10). The model-estimated 2005 storage of nitrate- $\mathrm{N}$ in the 10.8 -m-deep soil profile of site $\mathrm{N} 7$ analyzed in this model was $1,390 \mathrm{~kg} / \mathrm{ha}(1,689 \mathrm{~kg} / \mathrm{ha}$ in 2006$)$, indicating that $\mathrm{N}$ leaches well below the corn-root zone and accumulates in both the deeper vadose zone and underlying ground water with time (fig. 10). The model indicates (simulation results not shown) that continuing this practice of corn cultivation for the next 20 years (under current land-use practices and assuming the calendar 2005-06 weather data repeat over the next 20 years) will result in nitrate accumulation in the deeper vadose zone that will exceed current levels by more than $160 \%$ over the 6.8 to 10.8 -m-depth interval.

As mentioned in the methodology section, several management scenarios were simulated using reduced fertilization treatments as well as reduced irrigation totals while maintaining the same irrigation scheduling. Results suggest that reducing $\mathrm{N}$ fertilization by $50 \%$ using the same 2005 irrigation scheduling increases NUE significantly while achieving a maximum simulated crop yield, whereas decreasing $\mathrm{N}$ fertilization to $40 \%$ of the 2005 level achieves maximum NUE while maintaining crop yield within $0.1 \%$ of maximum (table 5). Lowering the $\mathrm{N}$-application rate from
$521 \mathrm{~kg} / \mathrm{ha}$ (the 2006 applied amount) to $427 \mathrm{~kg} / \mathrm{ha}$ (the 2005 applied amount), to $261 \mathrm{~kg} / \mathrm{ha}$ ( $50 \%$ of the 2006 amount), to $214 \mathrm{~kg} / \mathrm{ha}$ ( $50 \%$ of the 2005 amount) to 208 and $170 \mathrm{~kg} / \mathrm{ha}$ (the $40 \%$ amounts) consistently increased NUE from $38.9 \%$ to $42.2 \%$ to $76.4 \%$ to $85.6 \%$ to $91.1 \%$ to 93.7 , respectively (table $5)$.

Reducing irrigation total amount by various percentages ranging from $12 \%$ to $50 \%$ (but keeping the same irrigation scheduling) while maintaining $\mathrm{N}$-fertilization levels at the near-optimal value of $170 \mathrm{~kg} / \mathrm{ha}$ does not result in any NUE or grain-yield benefits, which means that the current irrigation practices are efficient and the used amounts near optimal (48.55 cm during the 2005 irrigation season-table 5).

Reducing the fertilization levels at the study sites to around $170 \mathrm{~kg} / \mathrm{ha}$ while maintaining currently used irrigation schedules and amounts increases the NUE significantly. Such lower fertilization rates can be achieved by blending treated wastewater effluent with freshwater from the underlying High Plains aquifer. (This was practiced during the initial years of the wastewater-irrigation operation but the practice was later abandoned - probably because of economic considerations.) As we mentioned in the wastewater and ground-water quality subsection, the deeper ground-water quality is generally good. Implementing a crop-rotation system using leguminous plants, such as alfalfa, will likely decrease the rate of build-up of $\mathrm{N}$ in the soil profile as seen in the profile of site R8 (fig. 8a), which has a history of alfalfa in the crop rotation. 


\section{Conclusions and Recommendations}

The analysis carried out in this report leads to the following conclusions:

1. Soil coring down to $15.2 \mathrm{~m}$ and ground-water sampling in the treated wastewater-irrigation area south of Dodge City, Kansas, indicated that nitrate-N is accumulating in the vadose zone and has reached the underlying ground water.

2. Soil coring and dye-tracing experiments demonstrated the existence of preferential pathways through macropores from decaying root channels throughout the sampled depths.

3. The near-surface residual soil nitrate-N peak in the soil profile is gradually propagating downwards in the soil, albeit attenuated, thus increasing the residual soil nitrate- $\mathrm{N}$ at depth. In addition, the nitrate- $\mathrm{N}$ in the underlying ground water is also progressively increasing with time.

4. The source of the nitrate- $\mathrm{N}$ in both the soil water and ground water in the treated wastewater-irrigated sites is shown to be from the treated wastewater applications.

5. Simulations using RZWQM indicated that high intensity rainfall events promote macropore preferential flows, which can transport nitrate deeper in the soil profile as indicated in items 1 through 3 above. However, we identified macropore conceptual limitations in the RZWQM in that the model does not allow macropore flow from water ponded over the subsurface layers of low-hydraulic conductivity.

6. Based on sensitivity analysis, the bulk density, saturated-water content, and Brooks and Corey parameters $\left(\lambda\right.$ and $\left.\psi_{\mathrm{a}}\right)$ are the most sensitive parameters affecting soil-water flow, whereas the CERES-Maize parameters P1, P5, G2, and G3 were the most sensitive plant parameters. Experimentally measuring the aforementioned hydraulic parameters will enhance soil-water simulations and consequently simulations of soil-nitrate transport, which will be further improved by carefully field-measuring the above-identified CERES-Maize parameters.

7. The RZWQM was calibrated for the 2005 planting season based on limited data and was tested/verified for the 2006 cropping season. The model acceptably approximated the overall patterns of the observed soil-water and nitrate profiles but not their detailed patterns, and generally overestimated the profile soil nitrate. In our judgment, better procedures for estimating the humus and microbial pools and plant-growth parameters as well as enhancement of the plant-growth module in the RZWQM will further improve the present state of $\mathrm{N}$ simulation. The incorporation of the Decision Support System for Agrotechnology Transfer, DSSAT4.0 suite of crop-growth models in the latest released RZWQM (RZWQM2, version 1.5), is a step in the right direction. Model results may also be improved by increasing the number of soil horizons that the model can handle and by obtaining additional soil hydraulic data (as also mentioned in item 6 above).

8. The calibrated RZWQM model was used to evaluate the impact of management practices using alternative reduced-N amounts on NUE and soil N. Thus, the model showed that reducing the wastewater $\mathrm{N}$-application rates to around $170 \mathrm{~kg} / \mathrm{ha}$ increases the NUE significantly.

Adopting such reduced-N application measures would definitely reduce the size of residual nitrate stored in the thick vadose zone in the area and slow down its downward migration. Combining such measures with a crop rotation that includes alfalfa should further reduce the amounts of residual nitrate in the soil.

\section{Acknowledgments}

This study was funded by the U.S. Geological Survey through the Kansas Water Resources Institute. Numerous people and agencies assisted us during the conduct of this study: Dr. Jay Jabro, research soil scientist with USDA-ARS Sidney, Montana, and Dr. Saseendran Anapalli, crop scientist with USDA-ARS, Fort Collins, Colorado, provided detailed and constructive comments that helped to improve this manuscript. Dr. L. R. Ahuja, Research Leader, Agricultural Systems Research Unit, USDA-ARS, Fort Collins, Colorado, provided useful comments on an earlier version of this manuscript and shared his insights on macropore flow. Kansas NRCS personnel J. Warner, S. Graber, R. Still, T. Cochran, and $\mathrm{C}$. Watts assisted us with field characterization and soilproperty lab analyses through the National Soils Laboratory in Lincoln, Nebraska. NRCS Soil Mechanics Laboratory in Lincoln, Nebraska, performed saturated hydraulic conductivity and related analyses. Dr. T. Willson and other personnel from the Garden City Experiment Station, Kansas State University, assisted us with neutron-probe readings and related analyses. D. Schuette of Servi-Tech assisted us with coring, sampling, and dye-tracer experiments. W. McCall of Geoprobe Systems assisted us with the Geoprobe equipment during fieldsite installations. The farmer-operator of the field sites $\mathrm{C}$. Nicholson and his office personnel assisted us with land-use information and access to the sites. K. Rojas of NRCS at Fort Collins, Colorado, assisted us with the RZWQM. Numerous other personnel from OMI and KGS assisted us at different stages of this project. Finally, our KGS colleagues Jim Butler, Marla Adkins-Heljeson, and Mark Schoneweis provided useful review comments, edited the manuscript, and perfected the figures, respectively. 


\section{References}

Abrahamson, D. A., Radcliffe, D. E., Steiner, J. L., Cabrera, M. L., Hanson, J. D., Rojas, K. W., Schomberg, H. H., Fisher, D. S., Schwartz, L., and Hoogenboom, G., 2005, Calibration of the Root Zone Water Quality Model for simulating tile drainage and leached nitrate in the Georgia Piedmont: Journal of Agronomy, v. 97 , p. 1,584-1,602.

Ahuja, L. R., and Williams, R. D., 1991, Scaling of water characteristic and hydraulic conductivity based on GregsonHector-McGowan approach: Soil Science Society of America, Journal, v. 55, p. 308-319.

Ahuja, L. R., DeCoursey, D. G., Barnes, B. B., and Rojas, K. W., 1993, Characteristics of macropore transport studied with the ARS Root Zone Water Quality Model: American Society of Agricultural Engineers, Transactions ASAE, v. 36, no. 2, p. 369-380.

Ahuja, L. R., Rojas, K. W., Hanson, J. D., Shaffer, M. J., and Ma, L., eds., 2000, Root Zone Water Quality Model-Modeling management effects on water quality and crop production: Water Resources Publications, LLC, Highlands Ranch, CO, 372 p.

Ahuja, L. R., and Ma, L., 2002, Parameterization of agricultural system models - Current approaches and future needs; in, Agricultural System Models in Field Research and Technology Transfer, L. R. Ahuja, L. Ma, and T. A. Howell, eds.: Lewis Publishing, p. 273-316.

Bond, W. J., 1998, Effluent irrigation-An environmental challenge for soil science: Australian Journal of Soil Research, v. 36, no. 4, p. 543-555.

Broadbent, F. E., Rauschkolb, R. S., Lewis, K. A., and Chang, G. Y., 1980, Spatial variability of nitrogen-15 and total nitrogen in some virgin and cultivated soils: Soil Science Society of America, Journal, v. 44, p. 403-432.

Brooks, R. H., and Corey, A. T., 1964, Hydraulic properties of porous media: Colorado State University, Fort Collins, CO, Hydrologic Paper 3.

Bruce, B. W., Becker, M. F., Pope, L. M., and Gurdak, J. J., 2003, Ground-water quality beneath irrigated agriculture in the Central High Plains aquifer, 1999-2000: U.S. Geological Survey, WaterResources Investigations Report 03-4219; http://pubs.usgs.gov/ wri/wri034219/pdf/wri034219.pdf (verified February 2009).

Cameira, M. R., Fernando, R. M., Ahuja, L. R., and Ma, L., 2007, Using RZWQM to simulate the fate of nitrogen in field soil-crop environment in the Mediterranean region: Agricultural Water Management, v. 90, p. 121-136.

Celia, M. A., Bouloutas, E. T., and Zarba, R. L., 1990, A general mass-conservative numerical solution for the unsaturated flow equation: Water Resources Research, v. 26, p. 1,483-1,496.

Dodge, D. A., Tomasu, B. I., Haberman, R. L., Roth, W. E., and Baumann, J. B., 1965, Soil survey Ford County, Kansas: U.S. Department of Agriculture, Soil Conservation Service, Series 1958, no. 32,84 p.

Dogan, E., Clark, G. A., Rogers, D. H., Martin, V., and Vanderlip, R. L., 2006, On-farm scheduling studies and CERES-Maize simulation of irrigated corn: Applied Engineering in Agriculture, v. 22 , no. 4 , p. $509-516$.

Flury M., Fluhler, H., Jury, W. A., and Leuenberger, J., 1994, Susceptibility of soils to preferential flow of water-A field study: Water Resources Research, v. 30, no. 7, p. 1,945-1,954.

Flury, M., and Fluhler, H., 1994, Brilliant blue FCF as a dye tracer for solute transport studies-A toxicological overview: Environmental Quality, v. 23, p. 1,108-1,112.

Flury, M., and Fluhler, H., 1995, Tracer characteristics of brilliant blue FCF: Soil Science Society of America, Journal, v. 59, p. 22-27.
Green, W. H., and Ampt, G. A., 1911, Studies on soil physics; 1 -Flow of air and water through soils: Journal of Agricultural Science, v. 4, p. 1-24.

Grossman, R. B., and Reinsch, T. G., 2002, Bulk density and linear extensibility; in, Methods of Soil Analysis, Part 4, Physical Methods, J. H. Dane and G. C. Topp, eds.: Soil Science Society of America, Series No. 5, p. 201-207.

Hanson, J. D., Rojas, K. W., and Shaffer, M. J., 1999, Calibrating the Root Zone Water Quality Model: Journal of Agronomy, v. 91, p. 171-177.

Hanson, J. D., 2000, Generic crop production; in, Root Zone Water Quality Model, L. R. Ahuja et al., eds.: Water Resources Publications, Highland Ranch, CO, p. 81-118.

Heaton, T. H. E., 1986, Isotopic studies of nitrogen pollution in the hydrosphere and atmosphere-a review: Chemical Geology, v. 59, p. 87-102.

Helsel, D. R., and Hirsch, R. M., 2002, Statistical methods in water resources; Chapter A3, Book 4, Hydrologic analysis and interpretation: U.S. Geological Survey, Techniques of Water-Resource Investigations, 510 p.; http://www. practicalstats.com/aes/aesbook/AESbook.html (verified February 2009).

Hem, J. D., 1985, Study and interpretation of the chemical characteristics of natural water: U.S. Geological Survey, Water-Supply Paper 2254, $263 \mathrm{p}$.

Hoefs, J., 2001, Stable isotope geochemistry, 4th ed.: Springer, $201 \mathrm{p}$.

Hu, C., Saseendran, S. A., Green, T. R., Ma, L., Li, X., and Ahuja, L. R., 2006, Evaluating nitrogen and water management in a double-cropping system using RZWQM: Vadose Zone Journal, v. 5, p. 493-505.

Kaehler, C. A., and Belitz, K., 2003, Tracing reclaimed water in the Menifee, Winchester, and Perris-South ground-water subbasins, Riverside County, California: U.S. Geological Survey, Water-Resources Investigation Report 03-4039.

Karamanos, R. E., Voroney, R. P., and Rennie, D. A., 1981, Variation in natural N-15 abundance of central Saskatchewan soils: Soil Science Society of America, Journal, v. 45, p. 826-828.

Kinney, C. A., Furlong, E. T., Werner, S. L., and Cahill, J. D., 2006, Presence and distribution of wastewater-derived pharmaceuticals in soil irrigated with reclaimed water: Environmental Toxicology and Chemistry, v. 25, no. 2, p. $317-326$

Kiniry, J. R., Williams, J. R., Vandelip, R. L., Atwood, J. D., Reicosky, D. C., Mulliken, J., Cox, W. J., Mascagni, H. J., Jr., Hollinger, S. E., and Wiebold, W. J., 1997, Evaluation of two maize models for nine U.S. locations: Journal of Agronomy, v. 89, p. 421-426.

Kozak, J. A., and Ahuja, L. R., 2005, Scaling of infiltration and redistribution across soil textural classes: Soil Science Society of America, Journal, v. 69, p. 816-827.

Kozak, J., Ahuja, L. R., Ma, L., and Green, T. R., 2005, Scaling and estimation of evaporation and transpiration of water across soil texture classes: Vadose Zone Journal, v. 4, p. 418-427.

Kreitler, C. W., 1975, Determining the source of nitrate in ground water by nitrogen isotope studies: Texas Bureau of Economic Geology, Report of Investigations No. 83, 57 p.

LECO Corporation, 1995, Carbon, nitrogen, and sulfur testing in soil/plant tissue: LECO Corporation, St. Joseph, MI, Form \# 203-821-002. 
Ma, L., Shaffer, J. J., Boyd, J. K., Waskom, R., Ahuja, L. R., Rojas, K. W., and Xu, C., 1998, Manure management in an irrigated silage corn field-Experiment and modeling: Soil Science Society of America, Journal, v. 62, p. 1,006-1,017.

Magesan, G. N., Dalgety, J., Lee, R., Luo, J., and van Oostrom, A. J., 1999, Preferential flow and water quality in two New Zealand soils previously irrigated with wastewater: Journal of Environmental Quality, v. 28, no. 5, p. 1,528-1,532.

Malone, R. W., Ma, L., Ahuja, L. R., and Rojas, K. W., 2001, Evaluation of the Root Zone Water Quality Model (RZWQM)-A review; in, Agricultural Non-point Source Water Quality Models - Their Use and Application, J. E. Parsons, D. L. Thomas, and R. L. Huffman, eds.: Southern Cooperative, Series Bulletin 398, 27 p.; http://www3.bae.ncsu.edu/RegionalBulletins/Modeling-Bulletin/RZWQM2-word.html (verified November 2007).

Mueller, D. K., and Helsel, D. R., 1996, Nutrients in the nation's waters - Too much of a good thing?: U.S. Geological Survey, Circular 1136, $24 \mathrm{p}$.

Pachta, C. J., 2007, Improving irrigated cropping systems on the High Plains using crop simulation models: M.S. thesis, Department of Agronomy, Kansas State University, Manhattan, KS, 126 p.

Pettygrove, G. S., and Asano, T., eds., 1985, Irrigation with reclaimed municipal wastewater-A guidance manual: Lewis Publishers, Inc., Chelsey, MI.

Rennie, D. A., Paul, E. A., and Johns, L. E., 1976, Natural nitrogen-15 abundance of soil and plant samples: Canadian Journal of Soil Science, v. 56, p. 43-50.

Ritchie, J. T., Singh, U., Godwin, D. C., and Bowen, W. T., 1998, Cereal growth, development and yield; in, Understanding Options for Agricultural Production, G. Y. Tsuji, G.

Hoogenboom, and P. K. Thornton, eds.: Kluwer Academic Publishing, Dordrecht, Netherlands, p. 79-98.

Roman-Paoli, E., Welch, S. M., and Vanderlip, R. L., 2000, Comparing genetic coefficient estimation using the CERESMaize model: Agricultural Systems, v. 65, no. 1, p. 29-41.

Saseendran, S. A., Ma, L., Nielsen, D. C., Vigil, M. F., and Ahuja, L. R., 2005, Simulating planting date effects on corn production using RZWQM and CERES-Maize models: Journal of Agronomy, v. 97, p. 58-71.

Shaffer, M. J., Rojas, K. W., DeCoursey, D. G., and Hanson, C. S., 2000, Nutrient chemistry processes-OMNI; in, Root Zone Water Quality Model-Modeling Management Effects on Water Quality and Crop Production, L. R. Ahuja, K. W. Rojas, J. D. Hanson, M. J. Shaffer, and L. Ma, eds.: Water Resources Publications, LLC, Highlands Ranch, CO, p. 119-144.

Shearer, G., Kohl, D. H., and Chien, S. H., 1978, The nitrogen-15 abundance in a wide variety of soils: Soil Science Society of America, Journal, v. 42, p. 899-902.

Shipitalo, M. J., and Edwards, W. M., 1996, Effects of initial water content on macropore/matrix flow and transport of surfaceapplied chemicals: Journal of Environmental Quality, v. 25, p. 662-670.
Sophocleous, M. A., Townsend, M. A., Willson, T., Vocasek, F., and Zupancic, J., 2006, Fate of nitrate beneath fields irrigated with treated wastewater in Ford County, Kansas-First-year Progress Report to KWRI: Kansas Geological Survey, Open-file Report 2007-14, 62 p.

Sophocleous, M. A., Ma, L., Townsend, M. A., Vocasek, F., KC, A., Willson, J., and Schuette, D., 2007, Treated wastewater and nitrate transport beneath irrigated fields near Dodge City, Kansas-Second-year Progress Report to KWRI: Kansas Geological Survey, Open-file Report 2007-25, 50 p.

Sophocleous, M. A., Townsend, M. A., Vocasek, F., Ma, L., and KC, A., 2009, Soil nitrogen balance under wastewater management-Field measurements and simulation results: Journal of Environmental Quality, v. 38, issue 3, p. 1,286-1,301.

Townsend, M. A., Sleezer, R. O., and Macko, S. A., 1996, Effects of agricultural practices and vadose zone stratigraphy on nitrate concentration in ground water in Kansas, USA: Water Science and Technology, v. 33, no. 4-5, p. 219-226.

Townsend, M. A., and Whittemore, D. O., 2005, Identification of nitrate and chloride sources affecting municipal well waters of the city of McPherson, Kansas: Kansas Geological Survey, Open-file Report 2005-34, 24 p.

Townsend, M. A., and Macko, S. A., 2007, Preliminary identification of ground-water nitrate sources using nitrogen and carbon stable isotopes, Kansas; in, Current Research in Earth Sciences: Kansas Geological Survey, Bulletin 253, part 3, 11 p.; http:// www.kgs.ku.edu/Current/2007/Townsend/Townsend_and_ Macko_CR.pdf.

Toze, S., 2006, Reuse of effluent water-Benefits and risks: Agricultural Water Management, v. 80, p. 147-159.

van Genuchten, M. Th., Leij, F. J., and Yates, S. R., 1991, The RETC code for quantifying the hydraulic functions of unsaturated soils: U.S. Environmental Protection Agency, Report 600/2-91/065.

Vengosh, A., and Pankratov, I., 1998, Chloride/bromide and chloride/ fluoride ratios of domestic sewage effluents and associated contaminated ground water: Ground Water, v. 36, no. 5, p. 815-824.

Vengosh, A., Spivack, A. J., Artzi, Y., and Ayalon, A., 1999, Geochemical and boron, strontium, and oxygen isotopic constraints on the origin of the salinity in ground water from the Mediterranean coast of Israel: Water Resources Research, v. 35, no. 6 , p. $1,877-1,894$.

Whittemore, D. O., 1995, Geochemical differentiation of oil and gas brine from other saltwater sources contaminating water resources - Case studies from Kansas and Oklahoma: Environmental Geosciences, v. 2, p. 5-31.

Williams, R. D., and Ahuja, L. R., 2003, Scaling and estimating the soil water characteristic using a one-parameter model; in, Scaling Methods in Soil Physics, Y. Pachepsky, D. E. Radcliffe, and H. M. Selim, eds.: CRC Press, Boca Raton, FL, p. 35-48.

Zupancic, J. W., and Vocasek, F. F., 2002, Dealing with changes in volume and quality of effluent at the Dodge City wastewater recycling project over the last sixteen years - 1986 through 2001: Irrigation Association, 2002 Technical Conference Proceedings, New Orleans, LA. 


\section{APPENDIX A}

RZWQM2 sensitivity graphs for soil hydraulic parameters (fig. A1), macropore properties (fig. A2), organic pools (fig. A3), and corn (CEREs-Maize) parameters (fig. A4).
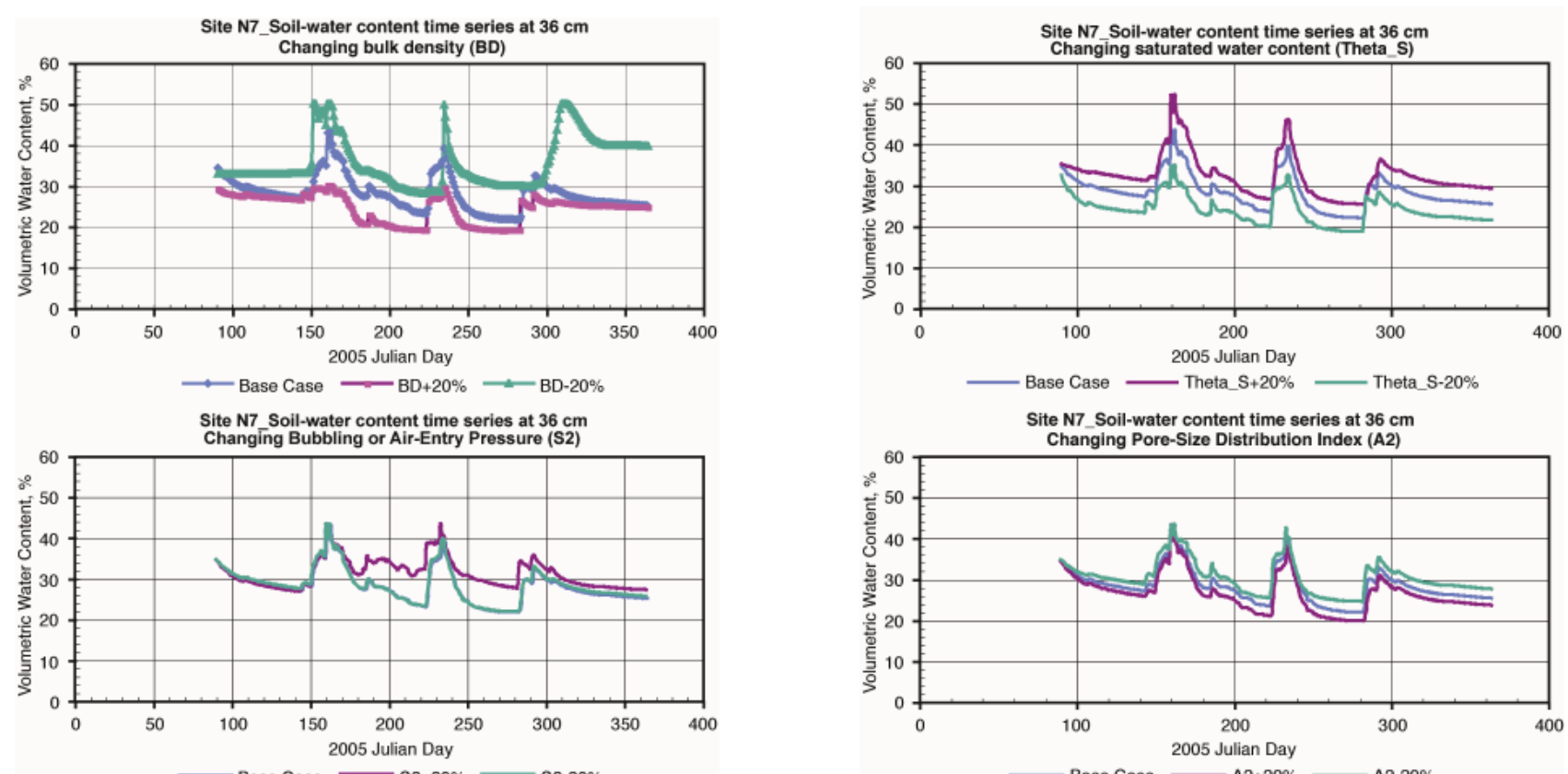

Base Case $-\mathrm{S} 2+20 \%$ - $22-20 \%$
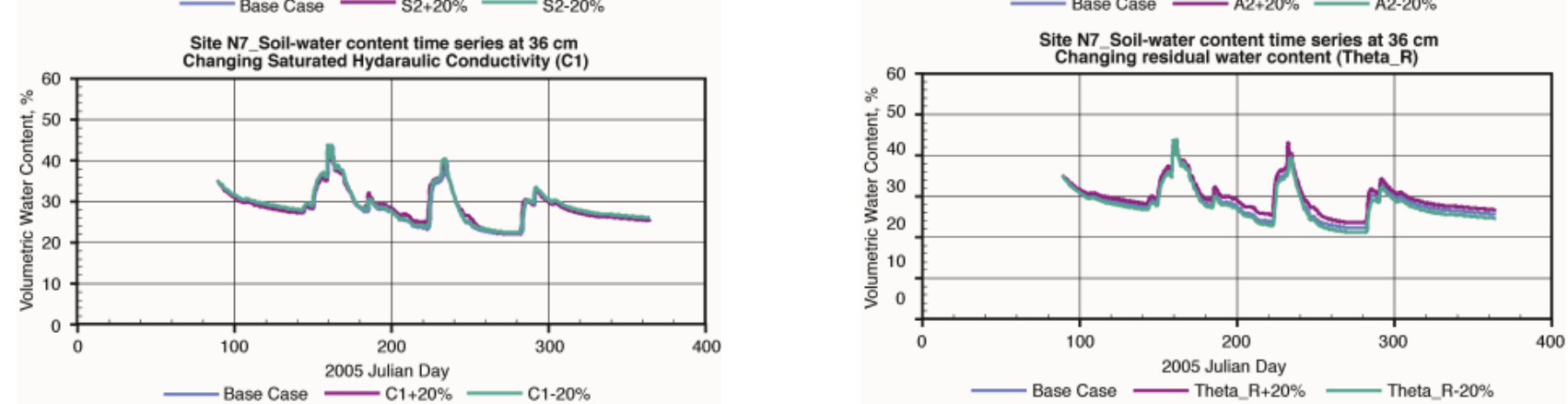

FIGURE A1-Sensitivity of simulated soil-water content to various soil hydraulic parameters compared to a calibrated base case for a randomly selected depth $(36 \mathrm{~cm})$ as a function of time. The indicated parameters were perturbed by $\pm 20 \%$ from those of the base case. 

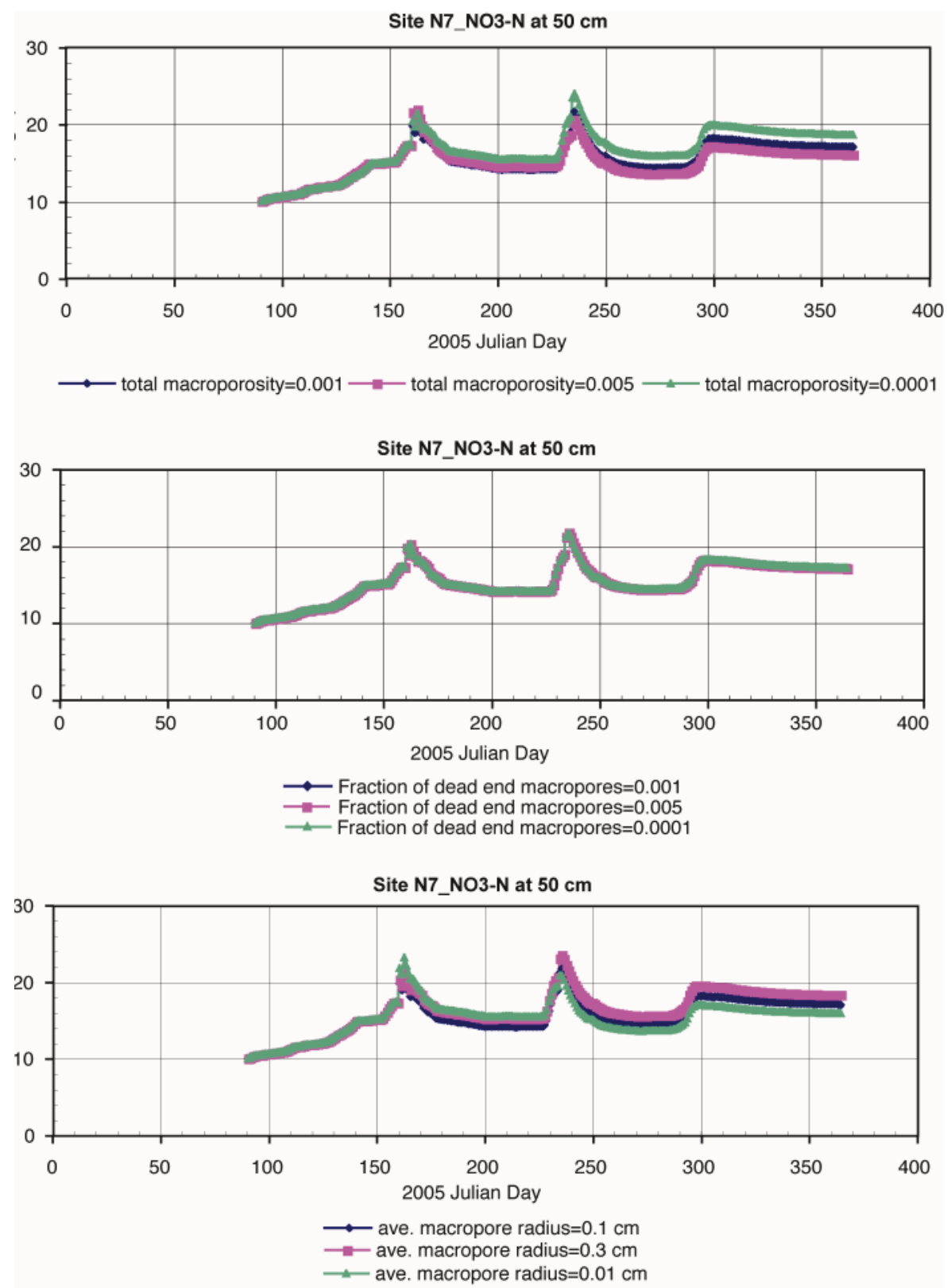

FIGURE A2-Sensitivity of simulated nitrate- $\mathrm{N}\left(\mathrm{NO}_{3}-\mathrm{N}\right)$ concentrations to various macropore parameters for a randomly selected depth (50 $\mathrm{cm})$ as a function of time. 

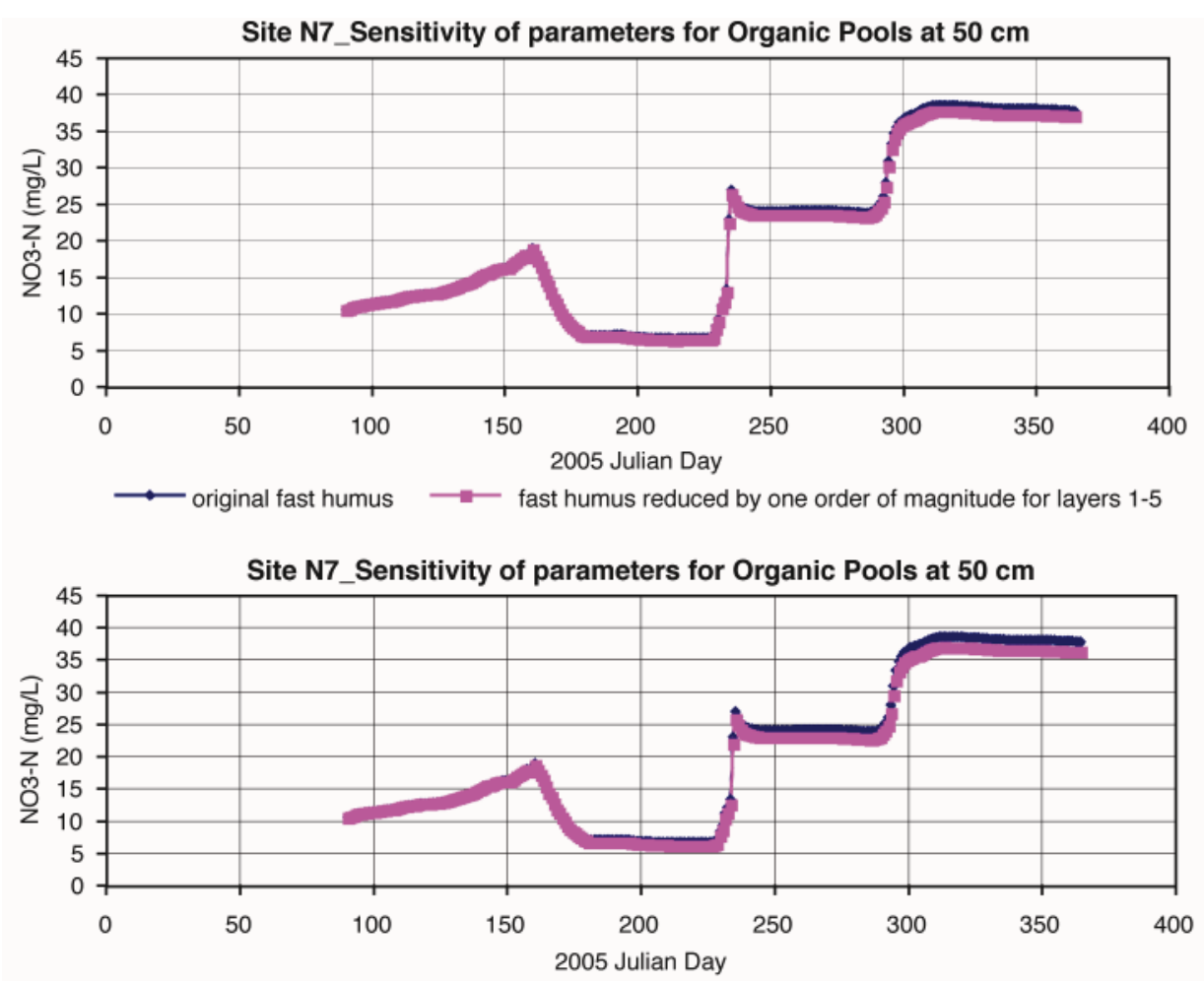

$\longrightarrow$ original transition humus $\longrightarrow$ transition humus reduced by one order of magnitude for layers $1-5$

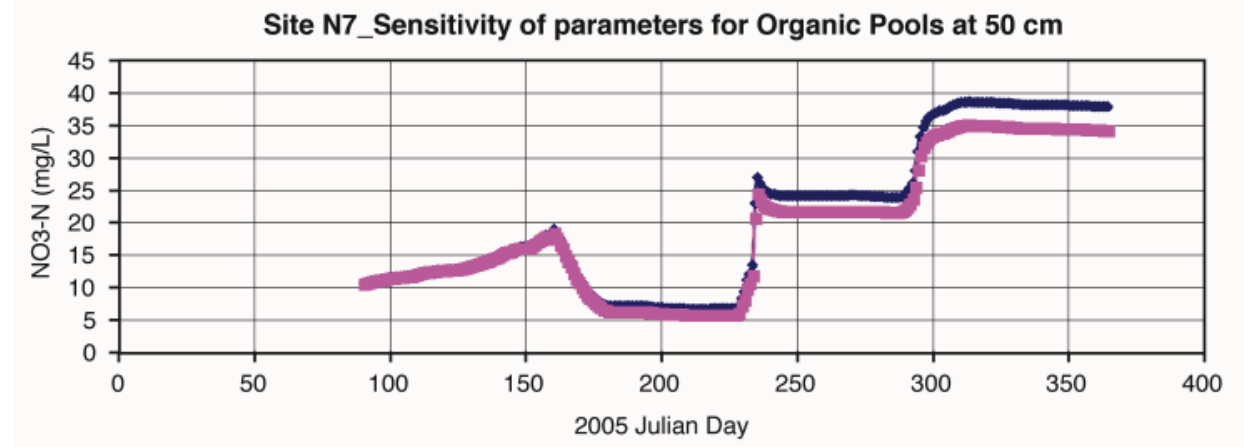

$\longrightarrow$ original aerobic heterotrophs —- aerobic heterotrophs reduced by one order of magnitude for layers 1-5

FIGURE A3-Sensitivity of simulated nitrate-N $\left(\mathrm{NO}_{3}-\mathrm{N}\right)$ concentrations to various organic pools in model layers 1 through 5 for a randomly selected depth $(50 \mathrm{~cm})$ as a function of time. 


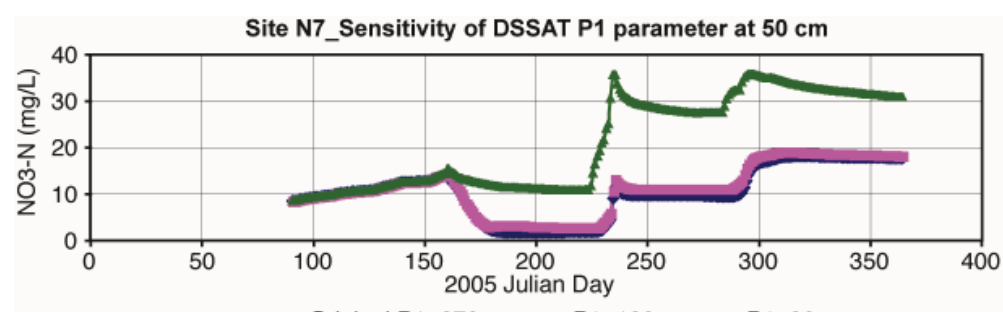

$\longrightarrow$ Original P1=270 $\longrightarrow \mathrm{P} 1=180 \longrightarrow \mathrm{P} 1=90$
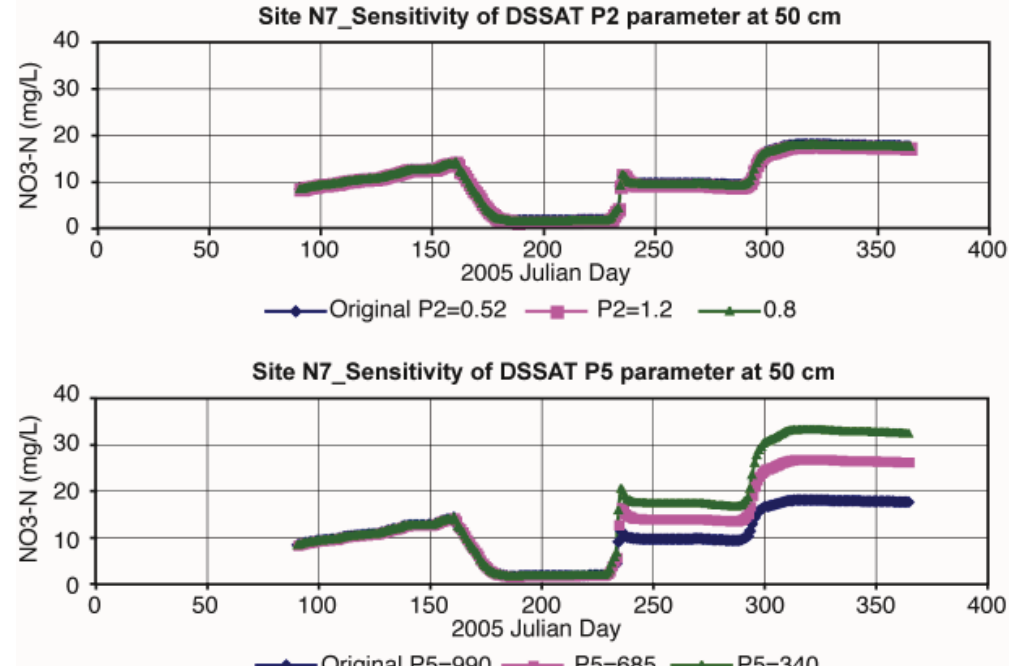

$\longrightarrow$ Original P5=990 — P5=685 —P5=340

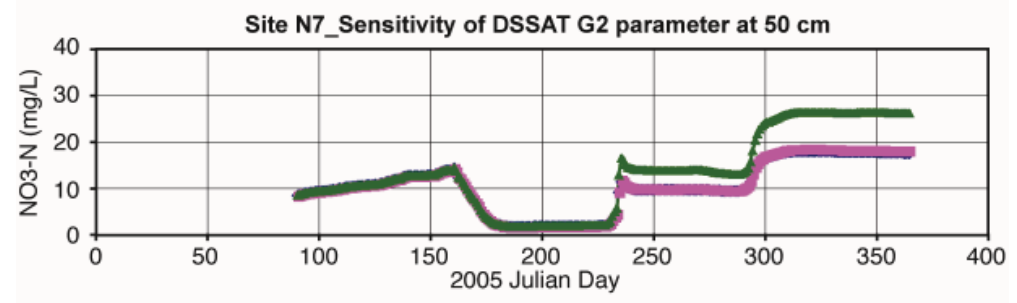

$\longrightarrow$ Original G2=1100 — G2=900 —G2=450

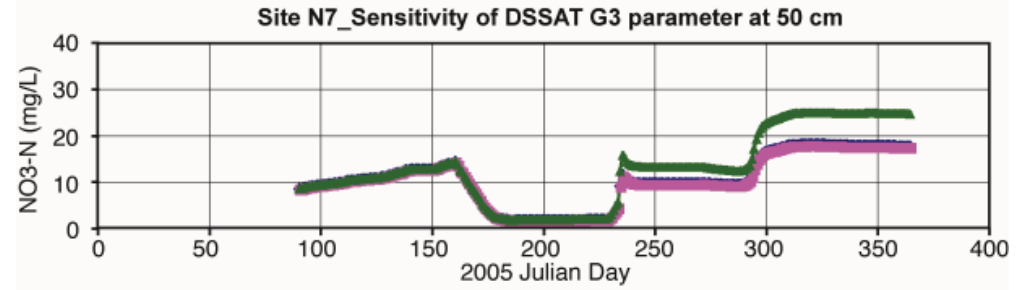

$\longrightarrow$ Original G3=10 $\multimap$ G3=15 $\multimap$ G3=5

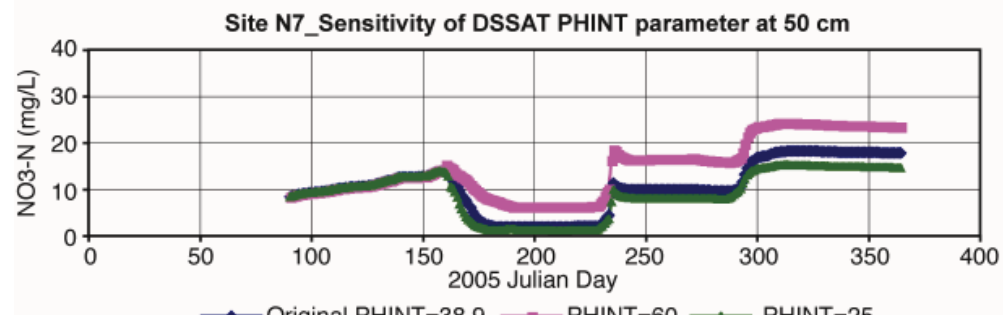

$\multimap$ Original PHINT=38.9 $-\mathrm{PHINT}=60 \multimap$ PHINT $=25$

FIGURE A4-Sensitivity of simulated nitrate-N $\left(\mathrm{NO}_{3}-\mathrm{N}\right)$ concentrations to various CERES-Maize parameters (see table 4) for a randomly selected depth $(50 \mathrm{~cm})$ as a function of time. 